
$P_{O}$

\&

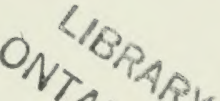




$$
\text { - }
$$


Digitized by the Internet Archive in 2011 with funding from University of Toronto 




\section{CONTRIBUTIONS OF THE}

\section{ROYAL ONTARIO MUSEUM OF ZOOLOGY}

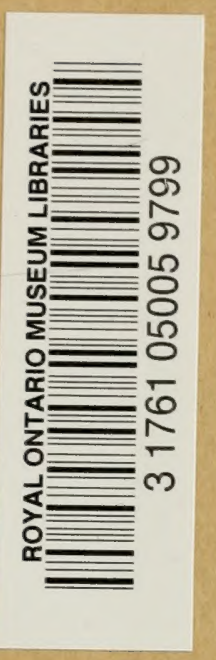

No. 8: THE DISTRIBUTION OF BREEDING BIRDS IN ONTARIO, By James L. Baillie Jr. and Paul Harrington D.D.s.

Part I-Reprinted from Trans. Roy. Can. Ist. Vol. XXI, Part I, 1936 Part II-Reprinted from Trans. Roy. Can. Ist. Vol. XXI, Part 2, 1937 

By James L. Baillie, Jr. and Paul Harrington, D.D.S.

\section{PART I}

The present account is an initial attempt to outline the breeding ranges of birds in Ontario. It represents the result of more than twelve years of researches on the part of the authors (in their leisure time) and although strictly a provisional account, it is their hope that it will serve as a summary of the known ranges in Ontario of breeding birds until such time as a comprehensive work on the birds of the province can be published.

Data are meagre for a great many species and completely lacking for others which unquestionably remain in the province to nest, but it is hoped that this very paucity will serve as a stimulus to naturalists to place on record whatever important unpublished information they possess.

Eight lists of the birds of Ontario, as a whole, have been published, but they have contained very little definite data on the distribution of birds within the province. Statements like "breeds throughout its range" and "nests throughout southern Ontario" have characterized these lists and such statements have failed to convey an adequate impression of the nesting range of any species. $\dagger$

*Contribution No. 8, Royal Ontario Museum of Zoology.

$\dagger$ The first of these lists which included in its scope the whole of what was then Ontario was Robert C. Gourlay's almost unannotated list ${ }^{1}$ of the birds of Upper Canada, published in London, England, in 1822. It enumerated 37 species of birds by the common names by which they were known here at the time. In 1851 a second list of Ontario birds ${ }^{219}$ (listing 72 species from Upper Canada) was published by William $\mathrm{H}$. Smith. Eight years later, in June, 1859, there appeared "A List of Birds found in Upper Canada"' written by Thomas J. Cottle of Woodstock, Ontario and published in the fourth volume of the Canadian Naturalist and Geologist. Cottle listed 145 species by their Latin names, with virtually no details and based largely on the author's own observations. In 1886 there appeared the first edition of Thomas McIlwraith's "Birds of Ontario"'3 in which accounts were given of 296 species occurring in the province, but the records upon which the work was based came mostly from the larger centres in extreme southern Ontario, leaving the vast area of what is now northern Ontario practically untouched so far as any account of its avifauna was concerned. In 1893 James H. Fleming's list of Ontario birds ${ }^{4}$ was prepared for the World's Fair, Chicago, and published by the Ontario government. In it, 322 species were listed, and brief comments were made on their distribution. McIlwraith's second edition ${ }^{5}$ appeared in 1894 and enumerated 309 species, being a reprint of his first edition, with a few additions and corrections. In 1900 there appeared Charles W. Nash's "Check list of the Birds of Ontario"6, which listed 300 species with rather vague distributional information, followed by his revised list ${ }^{7}$ of the same title (which treated 315 species) in 1905, which is our most recent list of Ontario birds. 
Excellent local lists and other valuable avifaunal records have been published, however, especially during more recent years, of the birds of certain localities within the province. Although many of these accounts (for example those published by Snyder from the regions of Lake Nipigon $^{19}$, Lake Abitibi ${ }^{31}$, King township ${ }^{60}$, and Long point ${ }^{27}$ ) contain information from previously unknown regions ornithologically, they have appeared in a variety of publications, making it virtually impossible to obtain definite distributional information without a laborious search of the literature.

The authors have attempted to bring together these scattered writings on Ontario birds and as a result there is on file at the Royal Ontario Museum of Zoology an index to the literature pertaining to the ornithology of the province which is gradually nearing completion. This bibliography was commenced by J. L. Baillie in 1924 and already there are more than ten thousand specific cards on file from upwards of one thousand titles. These records form the basis of the present account and those to which we have referred will be found in the list of literature cited.

Manuscript lists of the breeding birds of various localities within Ontario have been sent to the authors by well-known observers for inclusion in this account and to these data we have added whatever additional unpublished material has been available. We have listed (alphabetically by counties and districts) in small type under each species those records which add materially to the information already published, and wherever possible, new records are given for ten counties.

Of the manuscript data placed at our disposal, the most important have been the lists of breeding species furnished by the nine naturalists listed below, to all of whom we express our thanks. Their records, plus the records of the authors, constitute nearly fifty per cent. of the total number of new breeding records recorded in this paper. These contributors are the late Edwin Beaupre of Kingston (for thirty-five years an active oologist in Frontenac County), Lieut.-Col. Lionel S. Dear of Port Arthur (who has been in close touch with the bird-life of southern Thunder Bay District since 1923, and at irregular intervals prior to that date), Dr. Frederic A. E. Starr of Sudbury (who has been actively engaged collecting data on nests and eggs in York, Elgin, Sudbury and Victoria regions since 1915), Richard D. Ussher of King (who has furnished lists of the breeding birds of parts of Algoma, Cochrane, Thunder Bay and York regions), William E. Saunders of London (whose journals covering more than fifty years of observations in southern Ontario have been at our disposal), Dr. C. H. Douglas Clarke (Huron, Algoma, Nipissing and Parry Sound breeding records), Clifford E. Hope of the 
Royal Ontario Museum of Zoology, Toronto (records from various southern Ontario counties), Alfred Kay of Port Sydney (for over sixty years an active naturalist in northern Muskoka District), and H. Percy Bingham of Barrie (Simcoe County nesting data).

In addition, we are incorporating the results of observations made during more than twenty years' summer residence in the south Georgian Bay region by Paul Harrington and certain information secured by both authors in various sections of the province since 1920. Records given anonymously are recorded on the joint authority of the authors, and these constitute approximately twenty per cent. of the new records herein recorded.

The collections of birds, nests, eggs and records in the National Museum of Canada at Ottawa (N.M.C.), the Royal Ontario Museum of Zoology at Toronto (R.O.M.Z.) and in the possession of various private naturalists have been freely consulted for information, to each of whom we express our thanks. The fact that the most important source of definite breeding data is to be found in such collections needs scarcely be stated.

The thanks of the authors are due to Mr. J. H. Fleming and Mr. L. L. Snyder of the Royal Ontario Museum of Zoology for much assistance and for their checking of the manuscript and to Mrs. Phyllis Oughton of the Museum, whose co-operation by typing and retyping a very tedious manuscript is hereby gratefully acknowledged. The map has been drawn by Mr. Terence M. Shortt of the Museum, to whom we express our indebtedness.

More than two thousand individual breeding records are herein published for the first time, on the authority of no fewer than 238 observers. Suffice it to say that without such hearty co-operation a work of this kind would be quite impossible.

The list contains 210 species known to have bred in the province and the arrangement of species and the names used correspond to the "Birds of Canada", by P. A. Taverner, 1934. It is scarcely necessary to add that the absence of any species from the list may be taken as meaning that no indisputable record of nesting is available.

An interesting comparison is afforded by Lawrence E. Hicks' recent statement ${ }^{207}$ that 181 species are known to have nested in Ohio, which has an area of only 40,740 square miles compared to Ontario's 412,582 square miles.

Some further idea of the extensiveness of Ontario is found in the fact that the province is some 1015 miles across and 1085 miles from south to north. Of this great area little is known of the northern half or fifty per cent. of the province lying to the north of about Lake Nipissing 
and Sault Ste. Marie and it is a fact that fully ninety per cent. of the ornithological work in Ontario has been done in the southern ten per rent. of the province. Striking evidence of the need for some study of the nesting species along the extreme northern sea-coast of Ontario is (1) be found in a perusal of the recently-published "Birds of Churchill, Manitoha" (a locality just north of our limits), where no fewer than 31 species nest for which there are no Ontario breeding records.

Whatever records we have been able to find for northern Ontario simply hear out the statement of the late E. Howe Forbush that "The ranges of bircts as now recorded in unsettled regions are dependent not so much on the actual distribution of birds as on the distribution or wanderings of ornithologists".

\section{COMMON LOON GAVIA IMMER}

The Loon is one of the most characteristic water birds of Ontario, probably breeding in all suitable lakes throughout the province and definitely from the southern border to James bay ${ }^{8},{ }^{94}$ and west to Lake of the Woods ${ }^{12},{ }^{176}$. To the north of this, in extreme northern Ontario, it has been observed several times on the west coast of Hudson bay (at Churchill, Manitoba ${ }^{9}$ ) as well as at Severn House, on Severn river ${ }^{193}$.

On most lakes throughout its range the Loon is a fairly common and very conspicuous summer resident, but in lower Ontario its numbers have been reduced ${ }^{127},{ }^{156}$ due to the increase of settlement and the consequent reduction of its chosen habitat.

The race breeding in extreme northern Ontario may be immer elasson, but the one occupying most, if not all, of Ontario is considered to be immer immer.

Cochrane District, Smoky Falls, north of Kapuskasing-Two families of young were seen on July 1,1933 by R. V. Whelan.

Frontenac County - Set of two eggs in R.O.M.Z. was found at Collins' lake on May 19, 1915 and nest with two eggs was found at Draper lake on June 25, 1900 , both by E. Beaupre.

Kenora District-At High lake, near Shoal lake, Lake of the Woods, it was found breeding in 1920, according to letter from W. Rowan; D. R. Derry found eggs on June 26, 1930, along the Manitoba boundary between Lat. 53-54 ${ }^{\circ} \mathrm{N}$.

Leeds County - Nest with two eggs was found at Delta on June 14, 1932 by C. L. Broley and set of two eggs in R.O.M.Z. was taken by C. J. Young on June 30,1898 , at Higley lake.

Lennox and Addington County, Otter lake, Ashby township-Two downy young were seen on June 13, 1934 by J. M. Speirs.

Nipissing District, Lake Temagami-Nest with two eggs was found on July 18 , 1930, and nest with two eggs on June 11, 1926, both by A. F. Coventry.

Simcoe County, Barrie-H. B. Haugh collected a set of two eggs on May 25, 1918. 
Sudbury District-P. Harrington has a set of two eggs taken at Bigwood on May 24, 1913 and a set of two eggs in R.O.M.Z. was secured by A. E. Allin at Lake Welcome on June 15, 1911.

Thunder Bay District, Port Arthur-Nest with two eggs was found on June 7, 1914 , by L. S. Dear.

Victoria County-Nest with one egg was seen by us on June 11, 1932, on Muskrat island, Sturgeon lake and a nest was found on June 2, 1931 on Washburn island, Lake Scugog by P. Harrington, F. Starr and A. E. Allin.

\section{RED-THROATED LOON GAVIA STELlatA}

This loon is much more northern in its distribution than the Common Loon, and in Ontario it is known to have nested only on the north shore of Lake Superior.

W. E. Saunders ${ }^{10}$ in 1922 placed on record his belief that the Redthroated Loon probably bred in the vicinity of Lake Superior, his assumption being based on his collection of a female from fish-nets at Rossport on June 20, 1911. His prediction was fulfilled the following year when a nest (described below) was found at a locality seventy miles west of Rossport.

Its occurrence in the summer of 1848 at Sault Ste. Marie is recorded by L. Agassiz ${ }^{82}$, but Barrows ${ }^{49}$ states that "there is no reason to suppose that this diver ever nests in Michigan."

In 1914 the species was reported ${ }^{11}$ as common in August and September at Hudson bay, which would indicate that they breed also along the extreme northern border of the province. This belief is strengthened by a specimen of downy young in N.M.C. taken on July 27,1920 , by F. Johansen, at South Twin island, James bay, just outside of the boundaries of the province.

Thunder Bay District, Thunder Cape- - One record only, nest with two eggs on the point of hatching (and consequently not preserved), found on July 1, 1912. The nest was located on a small rocky island in Lake Superior near Thunder Cape. The island was about eighty yards long by forty yards wide and about fifteen feet high at the highest point. Its centre was covered with small scrub and it was in this scrub that the nest was located. The parent bird left the island as we landed and the pair was under observation through field glasses as they remained fairly close." (L. S. Dear).

\section{RED-NECKED GREBE colymbus grisegana}

This species is a rare summer resident of extreme western Ontario, west of Lake Superior. Actually, it has been found breeding only at Whitefish lake, some fifty miles west of Port Arthur ${ }^{14}$, but a set of four eggs in R.O.M.Z. taken on June 4, 1904, by I. Maharg at Lake of the Woods (Ontario?) indicates that the species may be found nesting in 
suitable areas between Lake Superior and Manitoba. Its occurrence aloc) in James bay is recorded ly Macoun ${ }^{12}$ and there is a specimen in R.O.M.Z. From Inose Factory, where it was secured in 1928 by $\mathrm{S}$. Viller. The form of this species occurring in North America is called Holboell's Grebe, grisegana holboelli.

Thunder Bay District, Whitefish lake-Apparently a very rare breeder. The first nests, both with four eggs, were found on June 18, 1933, by L. S. Dear and on June 13,1935 , we saw a nest with three eggs which had been discovered by F. Starr.

\section{HORNED GREBE COLYMBUS AURITUS}

It is difficult to ascertain the status of this grebe as a breeding bird of Ontario. Not only are its eggs practically indistinguishable from those of the commoner Pied-billed Grebe, but its nesting habits also bear a close resemblance to those of that species.

In the past the species has been recorded nesting more or less commonly at a few localities ${ }^{5},{ }^{15},{ }^{129}$ from Leeds County ${ }^{12}$, Ottawa ${ }^{13}$ and Lake St. Clair north to Port Arthur ${ }^{14}$ and Severn river on Hudson bay $y^{25},{ }^{193}$ but we have no hesitation in stating that all of these records, in our opinion, require confirmation.

The Horned Grebe, however, probably breeds at many places in northern and western Ontario, as it is known to nest rarely at Churchill, on Hudson bay ${ }^{9}$ and there is a fully-grown juvenile (with striping on head) in the collection of N.M.C., which was taken at Lac Seul, Kenora District, on September 6, 1919, of which P. A. Taverner says "probably but not certainly raised there."

In addition, W. P. Young collected a set of four eggs at Lake Nipissing on July 1, 1915, and this set is in R.O.M.Z. but particulars as to the identification of the parents of the nest are not at hand.

J. A. Morden assured W. E. Saunders ${ }^{181}$ in 1904 that H. P. Attwater and H. Keays trapped this species at its nest in June, 1882, at Lake St. Clair flats but Barrows" (1912) quotes Saunders to the effect that "he finds no evidence that the species has ever bred there." In this connection, it is of interest to note that Barrows was unable to find a single nesting record for this species in Michigan.

\section{PIED-BILLED GREBE PODILymbus PODICEPS}

This is the common grebe of southern Ontario ${ }^{141}$, nesting north to southern Cochrane and southern Thunder Bay Districts ${ }^{17},{ }^{109}$. There are few summer occurrences on record ${ }^{11},{ }^{16}$ for the vast territory north of these localities and no definite nesting records, so far as we are aware, 
although fully-grown young birds taken at Lac Seul (Kenora District) on August 26, 1919, by D. Blakeley (now in N.M.C.) may have been reared there and there is a female in R.O.M.Z. taken at Moose Factory, southern James bay on May 23, 1930 by S. Waller.

The North American form of this species is podiceps podiceps.

Cochrane District, Timmins-Several were seen attending half-grown but still downy and flightless young in early September, 1935, by J. M. Speirs.

Essex County, Point Pelee-Downy young, taken on June 11, 1913, by P. A. Taverner, is in N.M.C.

Frontenac County - Set of four eggs was found at Simcoe island on May 16, 1901 by $E$. Beaupre and a set of eight eggs found at Cataraqui on May 28, 1900 by E. Beaupre are in R.O.M.Z. Downy young taken at Kingston on July 5,1918 by P. A. Taverner are in N.M.C.

Middlesex County, London-W. E. Saunders secured a young bird on August 12, 1885 .

Norfolk County, Long Point-Nest and six eggs in R.O.M.Z. were secured on June 9,1932 by A. F. Coventry.

Parry Sound District, Frank's bay, Lake Nipissing-A young bird in R.O.M.Z. was secured at Sand creek on July 7, 1930 by W. R. Dymond and a nest in R.O.M.Z. was taken on June 10, 1933 (young left on 7 th) by C. H. D. Clarke.

Simcoe County, Little lake-Set of five eggs taken on May 24, 1919 by H. P. Bingham and set of seven eggs taken on June 16, 1918 by H. B. Haugh are in R.O.M.Z.

Thunder Bay District, Port Arthur-A few pairs breed on suitable lakes; nest with seven incubated eggs was found on June 16, 1929, according to L. S. Dear. We saw a nest with five eggs on June 13, 1935.

Victoria County-A young bird, in R.O.M.Z., was secured near Coboconk by H. Linton and a nest was found on June 2, 1931 on Washburn island, Lake Scugog by F. Starr, A. E. Allin and P. Harrington.

York County-Numbers formerly bred in the marsh at Ashbridge's bay, Toronto, according to J. Townson and a set of seven eggs, taken at Mugg's landing, Toronto island, on June 3, 1924 by W. P. Young is in R.O.M.Z. Adults were seen with five young on Kelly lake on June 9,1935 by R. D. Ussher.

\section{DOUBLE-CRESTED CORMORANT PHALACROCORAX AURITUS}

This fine bird is one of the rarer breeding birds of Ontario. It is known to nest at only five places in the northern and western parts of the province, all on small rocky islands, in the northern part of Lake Huron, on Lake Superior (at Agawa ${ }^{18}$ and near Port Arthur), at Lake Nipigon ${ }^{19}$ and in the Ontario part of Lake of the Woods ${ }^{20}$.

All of these breeding places have been discovered since 1924 but as long ago as 1912 W. E. C. Todd found ${ }^{20}$ a colony of thirty-six pairs nesting at Rupert's bay, on the east coast of James bay, Quebec, just outside of the boundaries of Ontario. This record suggests that additional breeding stations may be found in the extreme northern parts of the province. 
The Eastern Canadian form of this species is auritus auritus.

Algoma District, Isaac rock (Off Algoma mills) - A colony has been visited regularly since 1932 by W. I. Lyon, of Waukegan, Illinois.

Thunder Bay District, Black bay (30 miles east of Port Arthur) - A set of five eggs, taken from a colony there on June 3,1933 , by L. S. Dear is in R.O.M.Z.

\section{GREAT BLUE HERON ARDEA HERODIAS}

The (ireat Blue Heron is a fairly common summer resident of Ontario, breeding throughout the province ${ }^{1-8}$ from our southern border north at least to Temiskaming District and west to Lake of the Woods.

More than forty heronries are known to have been occupied within the past fifteen years.

Great Blue Herons are found sparingly north as far as James bay ${ }^{21},{ }^{2.5},{ }^{81}$ in summer and it is likely that their range limit as breeding birds is reached in that latitude.

The form occurring in Ontario is herodias herodias.

Frontenac County, Murvale-A set of three eggs taken on May 6, 1906, by E. Beaupre, is in R.O.M.Z.

Halton County, $6 \frac{1}{2}$ miles west of Oakville-A heronry of five nests was visited on May 14, 1934, by J. L. Baillie, C. M. Heddle and others. On April 29, 1935 , nine pairs were nesting there, according to $\mathrm{Mr}$. Heddle.

Kenora District, Lake Gordon, McIntosh-Heronry of 25 nests with young was found on June 22, 1933, by C. H. Hargrave, according to A. G. Lawrence.

Kent County, 6 miles east of Chatham-Colony of about 20 pairs was shown to us on June 11, 1933 by J. H. Smith.

Lincoln County, Secord's farm, near St. Catharines-Heronry of 47 nests was visited by G. J. Clout on June 6, 1935.

Manitoulin District, Green island, ten miles east of Killarney and three miles off shore-Large heronry was examined in July, 1931, by D. Strickland.

Ontario County, Thorah island (Lake Simcoe)-Fifty pairs were nesting on May 15, 1915, according to P. Harrington, and a set of five eggs was collected by him. In 1930 about 350 nests were occupied, according to J. A. Edwards, one tree containing eighteen nests. E. Dixon took a set of four eggs on May 6,1932 . This is the largest heronry in Ontario of which we have record.

Simcoe County, near Minesing-Heronry of fifty pairs ${ }^{161}$ was visited by us on May 9,1925 . On May 22, 1932, when the colony was again visited by us, eighty or more nests were counted.

Temiskaming District, Pharand township-A colony of 22 nests exists on an island in a bay on the south side of one of the lakes there, according to W. D. Pigott.

Thunder Bay District-Scattered colonies; a set of three eggs was secured at Port Arthur on May 13, 1932 by L. S. Dear. A heronry of eighty nests was reported in 1934 by G. Reed on Pakashkan lake, thirty miles north-east of Mack. 


\section{GREEN HERON BUTORIDES VIRESCENS}

The Green Heron is a not very common nesting species of the more southern parts of Ontario north to Middlesex², York and Grenville Counties.

Summer occurrences to the north of its known breeding range are rather frequent but these birds may have been wanderers or non-breeding individuals; one seen on August 18, 1934 at Skeleton lake, Muskoka District, by J. H. Williams and one seen on June 29, 1935, at Cameron, Victoria County, by H. M. Halliday and J. L. Baillie being the most northern records of its occurrence, although Barrows ${ }^{49}$ quotes an old record for Keweenaw point on the Michigan (south) shore of Lake Superior.

The Canadian form of this species is virescens virescens.

Elgin County, Aylmer-A set of three eggs in R.O.M.Z. was taken by R. T. Anderson in 1897.

Essex County-P. A. Taverner saw a nest in 1913 at Point Pelee; at Detroit river (Ontario) I. Maharg collected a set of three eggs on May 25, 1903.

Grenville County, below Burritt's rapids - Set of four eggs (originally five) in N.M.C. was $\operatorname{taken}^{23}$ on June 18, 1918, by P. A. Taverner.

Leeds County, Charleston lake-Set of five eggs, taken on June 14, 1899, by C. K. Clarke and C. J. Young, is in R.O.M.Z.

Lincoln County, St. Catharines-Nest with one egg was found by G. J. Clout on June 17, 1934.

Middlesex County, London-A set of five eggs was taken by W. E. Saunders on May 23, 1904.

Norfolk County, Waterford-F. Starr has a set of four eggs taken on May 21, i911, by W. Burton.

Ontario County, Frenchman's bay-Nest with young was found in 1928 by A. Twining.

Peel County-Four nests were found on June 25, 1911, by C. G. Harbour in the alders near Port Credit. One of the nests contained three eggs, two contained five young and the fourth contained four young. A nest with four young, taken at Cooksville on July 8,1935 , by J. Edmonds is in R.O.M.Z. J. L. Baillie and others saw a nest with five young at Erindale on June 20, 1934, shown to them by H. R. Ivor.

York County-At Lambton J. A. Edwards found a nest in a birch on June 16, 1925 (with two young and three eggs). and another (with five eggs) in a spruce on June 9, 1926, and at Humber Marsh, Toronto, R. A. Smith found a nest with two eggs on May 31, 1936.

\section{BLACK-CROWNED NIGHT HERON NYCTICORAX NyCTICORAX}

This heron has been known to nest in the province in only five counties ${ }^{23},{ }^{86}$ along our southern border. It is not common as a breeding species and is quite irregularly distributed. Pelee island is the only large nesting place at the present time, although others probably exist. Hicks ${ }^{207}$ records the existence of an extremely large colony on West 
Sister islands, Ohio (near Pelee island) but Barrows ${ }^{49}$ states that he knew of no record of its breeding in Michigan. Like most of the herons, immatures of this species wander northward after leaving their rearing places and the most northern record seems to be on the Magnetewan river ${ }^{32}$ near Emsdale, Parry Sound District.

The Canadian form of this species is nycticorax hoactli.

Essex County-At Pelee island a colony was discovered on August 9, 1930 by Professor Rudolf Bennitt of the University of Missouri'121. On June 6, 1932, F. H. Emery visited it or another colony and counted twenty nests; he returned on the 24 th and collected three young, which are in R.O.M.Z. On the 26th he found another occupied colony of eleven nests. On June 3 and 4 , 1933, Mr. Emery showed us the two colonies, in which we counted forty and ten nests respectively. On July 3, 1936, about 100 nests were occupied, according to $\mathrm{H}$. H. Southam.

Lambton County, St. Clair flats-Mr. Meredith told P. A. Taverner ${ }^{24}$ that there was a large colony breeding on the ground in the marsh at Walpole island in 1909 and P. Harrington has a set of three eggs taken from a large colony "at the flats" on May 14, 1921, by W. Purdy.

Wentworth County, Hamilton-Three nests (two young in trees) were examined on July 23, 1936 by G. W. North.

York County, Toronto-About four pairs nested in the dense willows near Leslie's nurseries, Ashbridge's bay, about 1872, according to J. Townson.

\section{AMERICAN BITTERN BOTAURUS LENTIGINOSUS}

This Bittern is a common nesting bird of Ontario, taking up its residence wherever there is suitable marshy habitat.

There is little doubt that it breeds throughout the province. Forster ${ }^{25}$ recorded its breeding at Severn river, on Hudson bay, it breeds at Moose Factory ${ }^{174}$ (as well as locally at Churchill, in Manitoba ${ }^{9}$ ), and generally in Ontario north from Lakes Erie and Ontario, west at least to Lake of the Woods.

Carleton County, Patterson's creek, Ottawa-Set of four eggs in N.M.C. was taken on May 25, 1900 by A. Wilson.

Essex County, Point Pelee-Young bird in N.M.C. was taken on July 9, 1913 by C. H. Young.

Frontenac County, Kingston-Two nests with four young were found on June 12, 1922 by E. Beaupre; one of these contained five eggs on May 17, 1922.

Kenora District, Ontario side of Indian bay, Lake of the Woods-Found breeding in 1920 according to letter from W. Rowan.

Kent County, Rondeau-Set of four eggs, in R.O.M.Z., was taken there on June 9, 1914, by A. A. Wood.

Ontario County, Simcoe point, Pickering-Nest with three young and one egg was found on June 23, 1935 by H. H. Southam.

Simcoe County-Nest with five pipped eggs was found on June 7, 1929, at Orr lake, nest with four eggs at Collingwood on June 3,1928 , nest with four eggs 
at Marl lake on June 6, 1929 and nest with five eggs at Mac on June 9, 1929, all by us.

Thunder Bay District-Nest with four eggs was found at Port Arthur on June 14,1929 by L. S. Dear and nest with two eggs was found on June 29, 1924 by R.D. Ussher near Makina lake on Upper Blackwater river, Lake Nipigon.

Victoria County, Bobcaygeon-Nest with three young and one egg and nest with four eggs were found by us on June 11,1932. The latter eggs are in R.O.M.Z.

York County-Nest with five young was found on June 9, 1935, by R. D. Ussher, at Kelly lake. J. L. Baillie saw young on the seventh Humber marsh, Toronto, on August 5, 1933.

\section{LEAST BITTERN IXOBRYCHUS EXILIS}

This is an uncommon breeding bird of the more southern sections of Ontario, north at least to the Bruce peninsula ${ }^{26}$ (west side of Georgian bay) Lake Nipissing and Ottawa ${ }^{23},{ }^{182}$. Its northern limit is probably southern Algoma District as it is known to nest ${ }^{213}$ at Manuscong bay, Michigan, in northern Lake Huron.

In a few localities it becomes quite common, for example at Marl lake (Simcoe County), Toronto and Long Point ${ }^{27}$, but even at these places it appears to occupy only certain favoured sections of the marshes, in little colonies, in which connection it is interesting to note that Barrows ${ }^{49}$ records that two collectors once found twenty occupied nests in a single day in Ingham County, southern Michigan.

A colour variety of this species (once considered a distinct species, Ixobrychus neoxena) formerly bred at Toronto.

Our form of the Least Bittern is exilis exilis.

Frontenac County, Collins' lake-Set of five eggs in R.O.M.Z. was found by E. Beaupre on May 31, 1904.

Kent County, Jeanette's creek-Set of four eggs taken by H. Gould on June 13, 1898, is in R.O.M.Z.

Middlesex County, London-Nested at W. E. Saunders' ponds in 1925, according to Mr. Saunders.

Nipissing District, near elbow of West bay, Lake Nipissing-Set of three eggs collected on June 24, 1934, by D. Chitty, is in R.O.M.Z.

Norfolk County-Adult was seen feeding young out of the nest in 1934 by H. Fulcher.

Ontario County, Frenchman's bay-Nest with two eggs was collected on June 9, 1929 , by C. E. Hope.

Peterborough County, Lakefield-Egg in R.O.M.Z. was secured about 1914 by A. M. Fitzgerald.

Simcoe County-Colony of six pairs was found at Marl lake on June 6, 1929. Two of the nests contained four eggs, three contained five eggs and one six eggs. Another nest with five eggs was found on June 5, 1928, all by us. There is a set of four eggs in R.O.M.Z. taken at Little lake on July 13, 1924 by H. P. Bingham.

Wentworth County, Hamilton-R. O. Merriman examined a juvenile on July 30 , 1921. 
York County, Toronto-Nest with five eggs was found on May 22, 1915 by P. Harrington at Humber marsh. J. H. Samuel and J. P. Turner found a nest with five eggs at Toronto island on June 25, 1899 and on June 25, 1891 J. I. Jackson took a set of four eggs (in R.O.M.Z.).

\section{CANADA GOOSE BRANTA CANADENSIS}

The Canada Goose breeds fairly commonly along the coasts of James $^{34}$ and Hudson bays ${ }^{12},{ }^{25},{ }^{68}$, between Moose river $^{8},{ }^{81},{ }^{175}$ and Churchill ${ }^{9}$. There is a downy young in N.M.C. taken at South Twin island (just beyond the borders of the province) in James bay on July 18 , 1920 by F. Johansen and Sir John Richardson ${ }^{178}$ quotes George Barnston to the effect that geese of this species were hatching on June 10,1839 ? (flying in August) at Martin's Falls, on the Albany river.

Recent maps ${ }^{134}$ indicate, perhaps correctly, that this bird may breed in the whole of northern Ontario, north of Lake Superior and the southern end of James bay.

The several instances of this bird nesting in southern and central Ontario almost undoubtedly concern injured or semi-domesticated individuals, and in this connection it is interesting to note that Barrows ${ }^{49}$ states that it once nested more or less commonly "all over" Michigan!

The subspecies breeding in Ontario is considered to be canadensis canadensis.

\section{MALLARD DUCK ANAS PLATyRhyNCHOS}

Typically a bird of the western prairies, the Mallard has been found nesting in Ontario at only a few localities, sparingly in the western section of southern Ontario ${ }^{28},{ }^{143}$ and not uncommonly in the extreme western part ${ }^{19}$ of the province, adjacent to Manitoba ${ }^{176}$.

It is probably a more or less common summer resident west of Port Arthur.

The Ontario Mallards are referred to platyrhynchos platyrhynchos.

Kenora District-At Indian bay, Lake of the Woods, it was found breeding (in 1920) "in the reedy corners of the bay and lakes and in the small swamps, scarce..." (W. Rowan ${ }^{29}$ ). Professor Rowan informs us that the above statement includes the Ontario or eastern end of Indian bay. It was found to be nesting commonly during the summer of 1930 on the Manitoba boundary between Lat. $53-54^{\circ} \mathrm{N}$. by D. R. Derry and Murray ${ }^{193}$ has recorded its presence at Severn House and Trout lake station in the extreme northern section of the province.

Thunder Bay District, Port Arthur-Not a common summer resident, according to L. S. Dear, who found a nest with eleven eggs on May 19, 1931. 


\section{BLACK DUCK ANAS RUBRIPES}

In Ontario the Black Duck is the most common and most widely distributed of the ducks, breeding from Lakes Erie and Ontario, north to Cape Hope at the mouth of the Severn river, Hudson bay ${ }^{30}$, the west coast of James bay ${ }^{12},{ }^{137}$ and west at least to Port Arthur ${ }^{176}$.

The form of this species occupying the extreme northern parts of Ontario $^{30}$ has been considered to be rubripes rubripes and the form in southern and central Ontario rubripes tristis, but even if two forms breed here, their respective breeding ranges have not been definitely worked out in Ontario.

Algona District, Lower Green lake, township 4B, Mississagi Forest reserveAdult was seen with brood of small young on June 22,1923 by R. D. Ussher.

Cochrane District-Juvenile male, collected between Moose and Albany rivers on July 3, 1920 by F. Johansen, is in N.M.C. A nest with eleven eggs was found near Kapuskasing on June 20, 1925, by R. D. Ussher.

Durham County, Cartwright township, on Lake Scugog-Very small young were seen on June 3,1924 by E. W. Calvert.

Essex County-W. E Saunders has a set of ten eggs taken at Point Pelee on May 4, 1913; we saw a brood of small young on Pelee island on June 3, 1933.

Frontenac County, Collins' lake-Three eggs from set of ten collected by E. Beaupre on April 28, 1905, are in R.O.M.Z.

Leeds County, Delta-Nest with ten eggs was found on June 14, 1932 by C. L. Broley.

Parry Sound District-Nest and one egg were found at Sans Souci on May 23, 1921 by P. Harrington. At Pickerel lake, east of Burk's Falls, J. L. Baillie saw six or eight large flightless young on July 14, 1935. A nest with five eggs is in R.O.M.Z., taken by C. H. D. Clarke at Frank's bay, Lake Nipissing, on June 10, 1933.

Sudbury District, Sylvanite lake, near Chapleau-Young were seen on July 22, 1934 by R. D. Black.

Thunder Bay District, Port Arthur-A nest with ten eggs was collected on June 12,1927 by L. S. Dear and a nest with seven eggs was seen by us on June 8, 1935.

Victoria County, Bobcaygeon-We saw parent with two young on June 11, 1932 and F. Starr found a nest with nine eggs on May 31, 1930.

\section{PINTAIL DAFILA ACUTA}

This duck is known to nest in Ontario only along the west coast of James bay, where W. Spreadborough ${ }^{12}$ found it breeding commonly, chiefly north of the Albany river, in 1904; and there is a young bird without wing-feathers in the Museum of Comparative Zoology, Cambridge, Mass., which had been secured at Fort George, Quebec, on the east coast of James bay.

It is a common nesting species at Churchill $^{9}$ (outside of our boundaries to the north-west) and it likely occupies the southern shore of 
Hudoon bay ${ }^{10 *}$ and the extreme western parts of the province ${ }^{134}$ (adjacent to Manitobat"2) as a more or less common summer resident. There is a single nesting reord for southern Ontario"s given below, and in addition, J. C. Phillips ${ }^{137}$ mentions that he "saw several late broods unal,e (o fly as late as October 2, 1916" at Long Point, on Lake Erie. Barrows ${ }^{19}$, gives a nesting record for the Michigan (west) shore of Lake Huron and Hicks's states that a few pairs breed regularly in Lucas. Ollawa and Sandusky. Counties, Ohio, on the south shore of Lake Erie.

The North American Pintail is acuta tzitzihoa.

Kent County, Erieau-A set of nine eggs, taken on May 22, 1890, by W. E. Saunders, is Set No. 3474 in his collection. He informs us by letter that the female bird was flushed from the nest.

\section{GREEN-IVINGED TEAL NETTION CAROLINENSE}

Little is known of the status of this duck as a breeding bird of Ontario.

It has been reported breeding commonly on both sides of James bay:1: (an adult female in N.M.C. was secured by F. Johansen on July 3 , 1920 between Moose and Albany rivers) and also in less numbers at Severn river, on Hudson bay ${ }^{25}$.

It probably breeds regularly also in the extreme western parts of the province, adjacent to Manitoba ${ }^{134}$. It is given as breeding also at Ottawa ${ }^{23}$, probably in error, and Barrows ${ }^{49}$ states that it used to breed on Neebish island, near Sault Ste. Marie, in Michigan.

\section{BLUE-WINGED TEAL QUERQUEDULA DisCors}

This little duck breeds sparingly ${ }^{33}$ throughout southern Ontario ${ }^{137}$ north at least to Lake Nipissing ${ }^{183}$ and Ottawa ${ }^{23}$. In the southern part of extreme western Ontario, between Lake Superior ${ }^{14}$ and the Manitoba boundary, the Blue-winged Teal probably also breeds ${ }^{29}$, the area is included in its nesting range in recent works ${ }^{134}$ and it is known to breed in Cook County, Minnesota ${ }^{176}$ adjacent to Ontario, on the west coast of Lake Superior and at Neebish island, near Sault Ste. Marie, Michigan. ${ }^{49}$

Strangely enough, the species nests also at Churchill ${ }^{9}$, in extreme northern Manitoba and there is a drake in R.O.M.Z. secured at Moose Factory, on James bay, on May 19, 1930, by S. Waller.

Essex County, Point Pelee-Nine one-day old juveniles, taken on June 6, 1913, are in N.M.C.

Lambton County, St. Anne's island, St. Clair flats-Bred there, according to J. Maughan.

Middlesex County, near London-A nest with eggs was found on June 18, 1926, according to W. E. Saunders.

Muskoka District, Port Sydney-Breeds, according to A. Kay. 
York County, Toronto-Brood of young was seen on August 10, 1933 by T. F. McIlwraith ${ }^{35}$ at Grenadier pond. R. J. Rutter and T. F. Mcllwraith saw two young with parent at Ashbridge's bay on July 11, 1931, where a pair nested in 1907 (eggs hatched August 7) and in 1912 (nest and eggs photographed by A. S. Goss, according to J. A. Munro.)

\section{SHOVELLER SPATUla ClyPEATA}

The only records of this western duck raising its young within the borders of Ontario are those of MacCallum ${ }^{218}$, who states that he saw parents with young on the Grand river near Dunnville, Haldimand County, in the summers of 1886 and 1887.

Hicks ${ }^{207}$ states that these ducks breed in four Ohio counties on the south shore of Lake Erie, and their nesting on the Ontario side of the same lake does not seem surprising.

\section{WOOD DUCK AIX SPONSA}

The Wood Duck is a rare nesting species in the more southern parts $^{156}$ of Ontario, north at least to Parry Sound District, ${ }^{39}$ north Hastings County ${ }^{12}$ and Renfrew County ${ }^{203}$ and probably somewhat northward as there are records of its occurrence ${ }^{184}$ at Mississagi marsh on the north shore of Lake Huron, from Kenora ${ }^{44}$ (Lake of the Woods), Sudbury ${ }^{16}$, Moose Factory and Trout Lake station ${ }^{193}$ in the extreme northern part of the province. Also Barrows ${ }^{49}$ states that it breeds in Marquette County, Michigan, on the south shore of Lake Superior.

Formerly its numbers were much greater than at present, and Long Point on Lake Erie appears to be one of its last strongholds in this province.

Grey County, Meaford-Female was seen with young in June, 1926, by W. J. Linn.

Hastings County, Madawaska river-Quite a number breed, according to J. Townson.

Muskoka District, Port Sydney-Breeds, according to A. Kay.

Norfolk County, Turkey Point-Seen with young by G. W. Knechtel, and a nest with young was located in a chimney, according to $\mathrm{H}$. Fulcher.

Peterborough County, Belmont lake, near Havelock-Young were seen on August 15,1897 , by J. H. Samuel.

Simcoe County, Nottawasaga river-Breeds sparingly, according to P. Harrington.

Wentworth County, Hamilton-Bred in the Dundas marsh, prior to 1877, according to C. W. Nash.

York County, Toronto-Three or more pairs formerly nested in the impenetrable bog behind Leslie's nurseries, and they bred also at Small's pond until 1880 , according to $\mathrm{J}$. Townson ${ }^{25}$. 


\section{RING-NECKED DUCK NYROCA COLLARIS}

Although this duck should occur during the breeding season in many parts of northern and western Ontario, the only known nesting places are at Lac Seul ${ }^{135}$ and at 11 hitefish lake, in southern Kenora and southern Thunder Bay Districts, respectively.

It has been found in summer also at Lake Abitibi" ${ }^{31}$, Cochrane District.

Kenora District, Lac Seul-Female and six downy young, taken on July 12, 1919 by D. Blakeley are in N.M.C.

Thunder Bay District, Whitefish lake - Set of nine eggs was taken on June 14, 1931 and another set of nine eggs was found on June 10, 1935 by L. S. Dear. The former set is in R.O.M.Z. We saw the latter nest with nine eggs on June 11, 1935, when they were collected by F. Starr. L. S. Dear also found two nests with eight eggs and one nest with thirteen eggs on June 16, 1929 .

\section{LESSER SCAUP DUCK NYROCA AFFINIS}

Formerly this species nested regularly in the larger marshes ${ }^{34}$ along the southern border of the province east to Toronto.

Now it is one of the rarest breeding ducks in the province and the only recent breeding record of which we are aware has been recorded by Townson $^{35}$ from Toronto.

Haliburton-Hastings Counties border, between Baptiste and Elephant lakesFemale was seen with brood of flightless young in the flooded timberland during the first week of September, 1923, by C. F. Haultain.

Lambton County, Walpole island, St. Clair flats ${ }^{36}$-A downy young bird, which was with five others on the parent female's back, secured about 1900 by W. G. A. Lambe, is in R.O.M.Z.

Ontario County, Frenchman's bay-A set of eggs was taken by H. V. McIntyre.

\section{COMMON GOLDEN-EyE GLaucionetta Clangula}

This is one of the most common and characteristic breeding ducks of the central and northern parts of Ontario ${ }^{12},{ }^{19},{ }^{25}$ from Lat. $45^{\circ 23},{ }^{144}$, to the shore of Hudson bay ${ }^{25},{ }^{100}$, west to Lac Seul, in Kenora District.

The North American subspecies is clangula americana.

Cochrane District-At Bank's lake, Staples township, near Kapuskasing, a female was seen with seven young on June 29,1925 by R. D. Ussher. E. Dixon has a set of six eggs from Lake Abitibi.

Kenora District, Lac Seul-Four flightless young, taken by D. Blakeley on July 21, 1919, are in N.M.C.

Muskoka District, Honey Harbour-Bred regularly, according to C. W. Nash.

Nipissing District, Temagami-Nests, according to A. F. Coventry.

Simcoe County, Orillia-A young bird, two-thirds grown, taken on September 14, about 1888, by Dr. Walker, is in R.O.M.Z.

Thunder Bay District-A nest and eight eggs were collected at Port Arthur on 
May 25,1931 by L. S. Dear. We saw a nest containing six eggs at Whitefish lake on June 7, 1935. These are now in the possession of F. Starr. Many broods of four to twelve young were seen along Blackwater river, Lake Nipigon, between June 26 and July 10, 1924 by R. D. Ussher.

\section{BUFFLE-HEAD CHARITONETTA ALBEOLA}

This little duck has been recorded as breeding at Severn river, on Hudson bay ${ }^{25}$ and in Sudbury District ${ }^{16}$ and as Bent ${ }^{32}$ includes the south-western coasts of Hudson and James bays in its breeding range, it likely nests in other parts of the northern sections of the province ${ }^{36}$. Murray ${ }^{193}$ records the species from Severn House, Trout Lake station and Moose Factory, in extreme northern Ontario.

Old records of the species breeding at the Lake St. Clair flats ${ }^{5},{ }^{12},{ }^{50}$ lack details and were probably erroneous.

\section{HOODED MERGANSER LOphodytes CuCullatus}

This small merganser, although not common and seldom recorded as a summer resident of Ontario, probably occupies ${ }^{41},{ }^{145},{ }^{154}$, the greater part of the province during the breeding season, in suitable unfrequented localities.

Its northern breeding limit is reached at northern James bay ${ }^{12}$ and probably in the vicinity of Lake of the Woods and the Minnesota boundary, as it breeds in Lake County, Minn. ${ }^{176}$ (adjacent to Ontario). Murray ${ }^{193}$ records the species from Trout Lake, in extreme northern Ontario.

Algoma District, Pangis-Three young were seen on August 21, 1925, by K. Christofferson.

Frontenac County, near Bob's lake-About April 28, 1905, two nests were found by $\mathrm{E}$. Beaupre, one with five and the other with seven eggs. The former set was in the possession of C. J. Young.

Lennox and Addington County, Buckshot lake-Young have been seen by C. H. D. Clarke.

Muskoka District, Port Sydney-S. L. Thompson saw a female with flock of young on July 26,1907 .

Nipissing District, Algonquin Park-Was found breeding in 1900 by W. Spreadborough.

Parry Sound District-Female was seen with at least one small young on July 16 , 1935 by J. L. Baillie at Pickerel lake, east of Burk's Falls and R. J. Rutter has seen young at Katrine.

Simcoe County, Jack's lake, Nottawasaga river-A female with seven downy young was seen by us on June 4, 1928.

Thunder Bay District, Saganogons lake-Nest and six eggs were collected on May 16, 1934 (eggs in R.O.M.Z.) and set of thirteen eggs on May 23, 1931 by L. S. Dear. 


\section{COMMON MERGANSER MERGUS MERGANSER}

The Common Merganser breeds rather commonly throughout Ontario from the Si. Lawrence river ${ }^{23}$ and Southern Lake Huron north to Lake Nipigon ${ }^{19}$ (and probably westward ${ }^{176}$ ) and northern Cochrane district ${ }^{8}, 12$. The North American form of this species is called the American Merganser, merganser americanus, by most authors.

Algoma District, Mississagi Forest reserve-Female was seen with six half-grown young on July 11, 1923 by R. D. Ussher.

Cochrane District, Bank's lake, Staples township, near Kapuskasing-Female was seen with young on June 24,1925 by R. D. Ussher.

Frontenac County, Horseshoe island-Set of four eggs was found on May 10, 1906, by E. Beaupre and set of nine eggs in N.M.C. was taken on May 12, 1903 by Beaupre.

Haliburton District, Maple lake-Female was seen with eighteen young July 3-6, 1935 by members of R.O.M.Z. field-party, L. L. Snyder, T. M. Shortt and C. E. Hope.

Lambton County, Kettle Point-Two females with about 18 small young were seen by J. M. Speirs on June 29, 1936.

Muskoka District-Flightless young in R.O.M.Z. were taken on July 12, 1900 by A. Kay at Port Sydney.. At Rebecca lake, W. C. Mansell observed a female with 26 young in July, 1934. At Go Home Bay a nest with seven eggs (one in R.O.M.Z.) was found in a chimney in May, 1935, according to A. T. DeLury.

Nipissing District-Downy young, secured on June 26, 1930, by A. F. Coventry at Lynx island, Temagami, is in R.O.M.Z. At Goose island, Lake Nipissing, W. E. Ricker found nests with eight and seven eggs on June 30, 1929, and a downy young in R.O.M.Z. was secured on June 10, 1929 by F. P. Ide, south of Sandy island.

Peterborough County, Belmont lake-Young were seen in the summer of 1897 by J. H. Samuel, according to his diary in the possession of J. H. Fleming.

Simcoe County-At Penetanguishene, a downy female was collected on June 11, 1935 by T. M. Shortt and at Barrie H. B. Haugh secured two downy young on June $26,1920$.

Thunder Bay District-Set of sixteen eggs taken at Saganaga lake on May 18, 1933 by J. D. Jacob, is in R.O.M.Z. At Port Arthur L. S. Dear found a set of eight eggs on June 8, 1913.

\section{RED-BREASTED MERGANSER MERGUS SERRATOR}

Little is known of the breeding of this merganser in Ontario. It is known to rear its young at the east end of Lake Ontario (in Frontenac and Lennox Counties), at the north shore of Lake Superior and Lake Nipigon $^{19}$ (Thunder Bay District), downy young have been taken on August 6, 1920, at Boat harbour, Great Whale river, on the Quebec side of Hudson bay (just outside of our province) and Phillips ${ }^{139}$ states that the United States Biological Survey has a record of its breeding at "Lake of the Woods"'12. 
It is decidedly less common than the American Merganser and is apparently of somewhat more northern distribution, nesting commonly at Churchill, Manitoba ${ }^{9}$ (on Hudson Bay) where the American Merganser is absent. Breeding records for Cook County, Minnesota ${ }^{176}$, suggest that its nesting range extends westward to the Manitoba boundary.

Frontenac County, Kingston-Set of seven eggs was taken by E. Beaupre on June 10,1910 .

Lennox and Addington County, Brothers island-A set of eight eggs in R.O.M.Z. was collected on June 28, 1905, by C. K. Clarke.

Thunder Bay District, Port Arthur-Fairly common breeder; set of eight eggs was obtained on June 22, 1932 by L. S. Dear.

\section{TURKEY VULTURE CATHARTES AURA}

The Turkey Vulture is known to breed (in small numbers) only in the extreme south-western counties of Huron, Lambton ${ }^{37}$ and Middlesex, in Grey County (south Georgian bay) in extreme western Ontario at Lake of the Woods ${ }^{29}$ and in eastern Rainy River District.

There are records of its summer occurrence, east to Lennox and Addington County and north to Moose Factory ${ }^{38}$ (June, 1898) and Fort Severn ${ }^{114}$ (August?, 1931) but definite neșting evidence is lacking, and the species is known to wander from its breeding places considerably.

Our form of this species is aura septentrionalis.

Grey County, Walter's Falls-One shot on July 7, 1934, by S. Craig, is in R.O.M.Z.; and another farmer reports finding a nest with one egg, according to L. H. Beamer.

Huron County, Grand Bend-Nests, according to W. E. Saunders.

Kenora District, Thompson's island, 7 miles south-west of Kenora, Lake of the Woods-Nest with two well-grown young was found among boulders on ledge on rock-cliff in July, 1919, by B. C. Brough. A photograph of one of the nestlings, by A. G. Lawrence, appeared in the Manitoba Free Press, December 7, 1935.

Middlesex County - Two young were obtained by C. Zavitz at Coldstream from a hollow log. They were mounted by J. A. Morden and are now in the Ontario Agricultural College at Guelph, according to A. A. Wood, who states also that he has a photograph of a nest with two eggs found near Denfield by R. McEwen.

Rainy River District, Knife and Basswood lakes, eastern section of districtNests have been found by Indians, according to J. D. Jacob.

\section{AMERICAN GOSHAWK ASTUR ATRICAPILLUS}

This is a rare breeding hawk of central ${ }^{12}$ and northern Ontario from Muskoka District and north Frontenac County to the Severn river (on the south shore of Hudson bay) ${ }^{25}$ west at least to Thunder Bay District, and probably to Lake of the Woods ${ }^{176}$.

There is a set of two eggs in N.M.C. taken at Great Whale river, 
Quebee ${ }^{171}$ and also an adult and two downy young secured on May 16 , 1912 at Chelsea, Quebec by F. C. Hennessey, both of which, of course, are just beyond the borders of Ontario.

The form of the Goshawk in eastern Canada is atricapillus atricapillus.

Frontenac County, Sharbot lake-E. Beaupre saw a set of eggs collected by C. J. Young on May 10, 1900.

Muskoka District, Port Sydney-Several nests have been seen by A. Kay and adult females in R.O.M.Z. were taken by him on June 9, 1890 and August 7, 1887.

Temiskaming District, Annina-Female and nestling taken on July 10, 1906, by W. B. Rubridge, are in the collection of J. H. Fleming.

Thunder Bay District, Port Arthur-Regular but very scarce breeder; a nest with three eggs was found on May 2, 1933 by L. S. Dear.

\section{SHARP-SHINNED HAWK ACCIPITER VELOX}

This small hawk is a fairly common and well distributed summer resident of the province north to High lake, near Ingolf (Lake of the Woods, Kenora District ${ }^{29}$ ) and Lake Abitibi ${ }^{31}$, breeding north and west to Thunder Bay District and probably throughout its summer range.

Its occurrence at Moose Factory is also recorded by Macoun ${ }^{12}$ and a male in R.O.M.Z. was secured there on May 22, 1930 by S. Waller.

The North American subspecies is velox velox.

Frontenac County, Sharbot lake-Set of four eggs, taken by E. Beaupre, on June 6,1905 , is in R.O.M.Z.

Hastings County, Madoc-Set of five eggs in R.O.M.Z. was found on June 7 , 1927 by E. Beaupre.

Huron County, Goderich-Young, just out of the nest, were found by C. H. D. Clarke, in August, 1933.

Middlesex County, Komoka-A set of five eggs was taken on May 29, 1915 by W. E. Saunders.

Ontario County - Set of five eggs (found by T. M. Shortt) taken on May 19, 1935 at Glen Major by R. V. Lindsay, is in R.O.M.Z. J. L. Baillie was shown a nest (in R.O.M.Z.) at Pickering by J. Edmonds on September 8, 1928 , from which five young had been reared.

Simcoe County, Barrie-Nest, female parent and three young, taken by H. B. Haugh on August 3, 1919, are in R.O.M.Z.

Sudbury District, Wahnapitae bay-Young just out of the nest were seen on August 1, 1929 by J. M. Speirs.

Thunder Bay District, Port Arthur--Set of five eggs was taken on June 1, 1913, by L. S. Dear.

Victoria County, Woodville-Set of five eggs was taken on May 30, 1931, by P. Harrington.

York County, Pottageville-Set of three eggs was taken by S. L. Thompson on May 15, 1933.

\section{COOPER'S HAWK ACCIPITER COOPERI}

This hawk is less common than the Sharp-shinned Hawk, especially in the north, but its breeding range is more southern than the range of 
that species, from the southern border ${ }^{128}$ north to Muskoka District, and west to Port Arthur.

Durham County, Port Hope-Set of five eggs in R.O.M.Z. was taken on June 3, 1903 by N. H. Meeking and T. Burt.

Essex County, Pelee island-Set of three eggs was taken by P. Harrington on June 4, 1933.

Frontenac County, Sharbot lake-Set of four eggs in R.O.M.Z. was taken on May 18, 1904, by E. Beaupre.

Leeds County, Westport-Nest with young was seen about August 1, 1934 by L. L. Snyder.

Lincoln County, Niagara-on-the-lake-Set of two eggs, taken on May 10, 1910, by F. Garrett, is in R.O.M.Z.

Muskoka District, Port Sydney-Female and set of three eggs in R.O.M.Z. were taken on May 13, 1927 by A. Kay.

Simcoe County, Jack's lake-Set of three eggs was taken on June 16, 1928, by P. Harrington.

Thunder Bay District, Port Arthur-Set of three eggs was taken on May 15, 1927, by L. S. Dear.

Wentworth County, Ancaster-Two eggs, taken from set of four on July 8, 1935, by D. Hassell, are in R.O.M.Z.

York County, Pottageville-Set of four eggs was taken on May 5, 1929 by S. L. Thompson.

\section{RED-TAILED HAWK BUTEO BOREALIS}

This hawk is a summer resident of Ontario ${ }^{9},{ }^{12}$ breeding fairly commonly north to Parry Sound ${ }^{39}$ and southern Thunder Bay Districts ${ }^{176}$ and possibly northward ${ }^{8}$, as the species was noted by R. D. Ussher during the summer of 1926 and by P. A. Taverner and C. E. Johnson in July, 1919 near Kapuskasing, Cochrane District ${ }^{94},{ }^{31}$, by the Museum party at Lake Abitibi during 1925 and D. R. Derry found it to be common during the summer of 1930 along the Manitoba boundary between Lat. $53-54^{\circ} \mathrm{N}$. The last-named record suggests that the western limits of its breeding range may coincide with the western limits of the province. It has been noted also along the Moose river by Spreadborough ${ }^{12}$, and at Churchill, Manitoba ${ }^{9}$.

Ontario birds are likely referable to borealis borealis.

Frontenac County, Sharbot lake-Bird was seen on nest on May 25, 1905 by E. Beaupre.

Huron County, near Auburn-Nest was found in 1934 according to R. Smyth.

Lincoln County, Smithville-Nest with young was found on May 19, 1935 by T. F. McIlwraith.

Middlesex County, Longwood-A set of four eggs was taken by W. E. Saunders on April 8, 1903.

Muskoka District, Port Sydney-Breeds, according to A. Kay. 
Northumberland County, Cobourg-Eggs were collected by N. A. Powell between 1861 and 1869 .

Parry Sound District, Gordon bay-Was seen with young on August 16, 1932 by J. L. Baillie.

Thunder Bay District, Port Arthur-Two nests with young were found on June 5, 1927 , by L. S. Dear.

Wellington County, Elora-Set of two eggs, taken on April 30, 1898, by J. D. Jacob, is in R.O.M.Z.

Wentworth County, Hamilton-Set of three eggs taken on April 6, 1905, by E. S. Norman, is in R.O.M.Z.

\section{RED-SHOULDERED HAWK BUteo lineatus}

The Red-shouldered Hawk is a not uncommon breeding species of southern Ontario, north to Lake Nipissing ${ }^{39}$ and east to Ottawa. It is somewhat more numerous than the Red-tailed $\mathrm{Hawk}^{12},{ }^{2}$ ? in many southern and eastern localities, but its range of course is considerably more restricted.

There are a few summer records for northern Ontario, including Lake Abitibi $^{31}$ (seen by R.O.M.Z. party in 1925) and southern Algoma district (noted during the summer of 1923 by R. D. Ussher in the Mississagi Forest reserve).

The Canadian race is lineatus lineatus.

Carleton County, Britannia-Parent female, set of four eggs and nest, taken by J. Arkell on April 20, 1929 are in N.M.C.

Durham County-At Bowmanville a nest with large young was seen on June 29, 1927 by A. E. Allin. A set of four eggs in R.O.M.Z. was secured on May 10, 1911, by N. H. Meeking at Port Hope.

Elgin County, Aylmer-Set of four eggs in R.O.M.Z. was collected by R. T. Anderson.

Essex County, Point Pelee-Nest has been found, according to W. E. Saunders.

Frontenac County, Crow lake-Set of two eggs, in R.O.M.Z., was taken by E. Beaupre on April 29, 1919.

Leeds County, near Lansdowne-Set of two eggs in N.M.C. was collected on April 16, 1898, by C. J. Young.

Muskoka District, Port Sydney-Breeds, according to A. Kay.

Peterborough County, Lily lake-A set of four eggs in N.M.C. was collected on April 24, 1900 by N. H. Meeking1:0.

Wellington County, Elora-A set of three eggs in R.O.M.Z. was taken on April 26,1898 , by J. D. Jacob.

York County-A nest with three eggs was found by us at Kleinburg on April 14, 1935. The set of eggs was collected by R. V. Lindsay on the 19th. At Highland creek, W. P. Young took a set of three eggs on May 25, 1910. Three young in nest at Pottageville (found by R. J. Rutter on April 20, 1935) were photographed and banded on July 13 by C. E. Molony and O. E. Devitt. At Weston, J. H. Fleming took a set of two eggs on April 1, 1894 (in R.O.M.Z.). 


\section{BROAD-WINGED HAWK BUteo PLATYPTERUS}

This is the most common and most characteristic summer resident hawk of central ${ }^{41}$ and northern Ontario, breeding from Middlesex County ${ }^{22}$ and Leeds County ${ }^{12}$ north at least to Thunder Bay and Sudbury Districts, somewhat less commonly in the south. There is little doubt that its breeding range extends north to James bay (as Spreadborough observed it commonly along the Moose river in June, 1896) and west to Lake of the Woods (noted during the summer of 1920 at Indian bay, Manitoba ${ }^{9}$ by Rowan).

North American Broad-winged Hawks are platypterus platypterus.

Frontenac County, Sharbot lake-Set of two eggs taken on May 25, 1905, by E. Beaupre, is in R.O.M.Z.

Haliburton District, Wilberforce-A set of three eggs is in the possession of E. Dixon.

Hastings County, northern part-E. Beaupre saw adult on nest on May 29, 1919.

Muskoka District, Port Sydney-Both parents and two nestlings, taken by A. Kay on June 26, 1900, are in R.O.M.Z.

Nipissing District, Cache lake, Algonquin Park-Was found breeding in 1900 by W. Spreadborough.

Parry Sound District, Sundridge-Nest with young has been found in August by J. M. Speirs.

Sudbury District, near Gogama-Nest was found in June, 1931, by J. A. Brodie. Temiskaming District-Two young were taken from nest near Haileybury in July, 1935 and sent to Toronto Zoo by P. O. Pronovost; J. H. Fleming has two young taken from nest at Annina on July 20, 1906 by W. B. Rubridge ${ }^{204}$.

Thunder Bay District, Whitefish lake-Nest was found on May 22, 1927 by L. S. Dear. It contained two eggs. We saw a nest with two eggs on June 2, 1935.

Victoria County, Bobcaygeon-Set of two eggs was taken on June 1, 1931, by P. Harrington, and we saw one at nest on June 11, 1932.

\section{BALD EAGLE haliaeetus leucocephalus}

The Bald Eagle is found locally in summer throughout the province ${ }^{21}$, breeding $^{37}$ from Lakes Erie and Ontario north at least to Lake Nipigon ${ }^{19}$ and Temiskaming District.

D. R. Derry noted the species on August 4, 1930, at Cocos lake on the Sagawitchewan river near Lat. $54^{\circ} \mathrm{N}$. on the Manitoba boundary, where its western breeding limit in Ontario is probably reached. Its northern limit may extend to James bay (one seen at Moose Factory on August 29, 1931 by T. F. McIlwraith). W. E. Saunders ${ }^{177}$ has estimated that the number of Bald Eagles in Ontario has been decreased ninety per cent. since the advent of the white man.

Our form is considered to be leucocephalus alascanus.

Frontenac County-W. E. Shelburne took a set of two eggs ${ }^{12}$ (in R.O.M.Z.) on Simcoe island on April 28, 1900, from a nest which had been occupied for 
thirteen successive years. C. J. Young and E. Beaupre collected a set of three eggs on Horseshoe island on April 16, 1901 and E. Beaupre took a set of three eggs on Horseshoe island on April 10, 1902.

Haldimand County, Port Maitland-Nest was occupied there in 1935 according to W. Gilmore.

Kent County, Rondeau-Pair was seen at nest on May 19 and 21, 1934 by J. L. Baillie and others.

Lambton County, Stony point - Downy young taken from nest on April 10, 1920, by A. A. Wood, is in R.O.M.Z.

Lennox and Addington County, Amherst island-Set of three eggs taken by E. Beaupre on April 3, 1921 is in R.O.M.Z.

Nipissing District, Temagami-Nest with at least two young was seen on August 19, 1929 by A. F. Coventry.

Norfolk County, Fisher's glen-Nest with one young was seen on farm of Harry Gundry on June 30, 1935 by A. Buchanan.

Parry Sound District, Frank's bay, Lake Nipissing-Nest with one young was seen on July 10,1930 by A. F. Coventry.

Temiskaming District, Swastika-Nest was seen on August 11, 1931 by H. H. Brown and H. G. Macklin.

Thunder Bay District, near Whitefish lake-L. S. Dear found a nest on May 4, 1931.

\section{MARSH HAWK CIRCUS HUDSONIUS}

The Marsh Hawk is one of the commonest, most conspicuous and most widely-distributed of the hawks of Ontario ${ }^{9},{ }^{12}$ breeding in suitable places from the southern border north at least to Lake Nipigon ${ }^{19}$ west to the Manitoba boundary and more than likely throughout most, if not all, of the province ${ }^{8},{ }^{25},{ }^{193}$, as the species was often seen during the summer of 1930 by D. R. Derry along the Manitoba boundary between Lat. $53-54^{\circ} \mathrm{N}$. and its abundance along both sides of James bay in July and August, 1904, is attested by Spreadborough.

Durham County-Nest with five eggs found by E. W. Calvert on May 15, 1924, contained four young and one addled egg on June 9, on Lake Scugog in Cartwright township. At Hampton, A. E. Allin found a nest with four eggs on July $5,1927$.

Essex County, Point Pelee-Set of three eggs taken by C. H. Young on May 24, 1912, is in N.M.C.

Frontenac County, Cataraqui-Nest with five eggs was found on May 11, 1924 by E. Beaupre.

Huron County, Goderich-Nest with six eggs was found on May 22, 1929 by C. H. D. Clarke.

Kenora District, Ontario side of Indian bay, Lake of the Woods-Bred fairly plentifully in 1920 , according to letter from W. Rowan.

Kent County, Rondeau-Nest found by us on June 12, 1933 contained four young and one egg.

Simcoe County-Nest with four eggs was shown to J. L. Baillie at Minesing on May 16, 1931 by T. M. Shortt and a nest with three young just hatched, was seen at De Grassi Point on June 10, 1934, by E. M. Walker. 
Thunder Bay District, Port Arthur-Set of six eggs was taken on May 24, 1924 and set of five eggs on June 16, 1924 by L. S. Dear.

Waterloo County, near New Hamburg-Nest with four eggs and two young was found on June 2, 1932 by R. D. Ussher.

York County-Nest with five eggs, found by C. E. Hope on May 19, 1929, was shown to J. L. Baillie on May 24 at Pottageville. At Ashbridge's bay, Toronto, S. L. Thompson photographed a nest with four eggs on June 9, 1926.

\section{OSPREY PANDION HALIAETUS}

The Osprey is a conspicuous and not uncommon breeding hawk of Ontario, from the east end of Lake Ontario and Victoria County north to Monse Factory ${ }^{12}$ and west to the Manitoba boundary at Lat. $53^{\circ} \mathrm{N}$. Canadian ospreys are referred to haliaetus carolinensis.

Algoma District, small lake near Kendogami lake, township 4C, Mississagi Forest reserve--Parent was seen on nest containing young by R. D. Ussher on July $3,1923$.

Frontenac County, Sydenham-Set of two eggs, taken by E. Beaupre on May 28, 1902 is in R.O.M.Z. and E. Beaupre took a set of three eggs on June 6, 1901.

Kenora District, Lake Mantaicia, Lat. $53^{\circ} \mathrm{N}$. on the Manitoba boundary-Nest was found in the summer of 1930 (young flying on July 2) by D. R. Derry.

Leeds County, Charleston lake-One egg from set of three taken on May 23, 1900 by W. E. Shelburne is in R.O.M.Z.

Nipissing District, Lower island in Hanging Stone lake, McCallum township-A nest, found in 1921, was occupied for at least six years previous to that according to $\mathrm{H}$. W. Swaine.

Parry Sound District, Noganosh lake-Nest was seen in mid-August, 1929, by W. E. Saunders and S. L. Thompson. Photographs of it were secured.

Peterborough County, Lake Koshamogabog, Methuen township-Some nests were seen in August, 1895, by J. H. Samuel, according to his diary in the possession of J. H. Fleming.

Sudbury District, Sylvanite lake, near Chapleau-Nest was seen in July, 1934 by R. D. Black.

Thunder Bay District-Scattered pairs nest on the tops of very high, dead pine stubs at Port Arthur, according to L. S. Dear, who collected one egg on May 30, 1929. R. D. Black found a nest (young nearby) on Fluor island, Nipigon straits, on September 5, 1931.

Victoria County-Occupied nest was seen on May 25, 1934 at Emily creek, Sturgeon lake, by F. Starr, who saw young out of the nest there on August 28, 1932. At Norland a nest with young was seen on August 19, 1933 by Margaret H. Mitchell. J. A. Edwards has a set of five eggs taken at Kirkfield on June 6, 1913 and at Balsam lake two young were taken from nest on July 26,1935 and sent to Toronto Zoo.

\section{PEREGRINE FALCON FALCO PEREGRINUS}

This Falcon is a rare breeding bird of Ontario but scattered pairs nest wherever there are suitable rock-cliffs north from Leeds ${ }^{12}$ and Grey 
Counties". Its northern limit appears to be reached in Thunder Bay District, although it seems likely that it extends northward probably to Hudson bay ${ }^{9},{ }^{12},{ }^{4}, 193$ and westward to along the Minnesota boundary ${ }^{176}$.

The American variety of this species is called Duck Hawk, peregrinus anatum.

Frontenac County, Crow lake-Set of five eggs taken on April 19, 1929 and set of two eggs taken on May 5, 1917 by E. Beaupre are in R.O.M.Z. On June 14,1920 , three young were at the nest and on June 9, 1921 two small young and one infertile egg according to Beaupre.

Grey County, Redwing - O. E. Devitt and F. H. Emery examined nest with four eggs on June 3, 1934 and saw young awing on July 1, 1933.

Haliburton District, Drag lake-Nest with young on cliff was found on June 24, 1933 by F. Starr.

Leeds County, Charleston lake-Two sets of four eggs in R.O.M.Z. were taken on May 2, 1901 (by W. E. Shelburne) and June 10, 1913 (by E. Beaupre). A set of four eggs was found also by Beaupre on April 23, 1903.

Muskoka District-Two pairs have nested regularly for nearly fifty years, one on Skeleton lake (near Ufford) and the other on Devil's Face near Asbin in Stisted township, according to A. Kay. Two young were raised at the latter place in 1934, according to J. H. Williams. At Honey Harbour, a nest with four eggs was photographed on May 17, 1931 by G. F. Smith (on the 24th two of the eggs had hatched). A set of two eggs in R.O.M.Z. was taken near Beaumaris about May 20, 1897 for P. A. Taverner.

Nipissing District, Algonquin Park-A nest was found on cliff near Rock lake on July 15, 1925 by W. E. Saunders, E. M. S. Dale and T. D. Patterson. Some boys had just taken one of the nestlings. At Hogan's lake, S. L. Thompson found a nest with young on cliff on July 18, 1910.

Parry Sound District, Pickerel lake, a few miles east of Burk's Falls-Nesting rock was discovered on June 15,1935 by $\mathrm{R}$. Scadding. On July 8 or 9 , the four young, in down, were removed alive from the ledge by a cottager and one of them was shown to J. L. Baillie on the 12th. On May 24, 1936 a set of three eggs was secured by C. Scadding; these are now in the collection of P. Harrington.

Thunder Bay District, Port Arthur-Nest with four young (about one week old) was found on June 4, 1933 by L. S. Dear.

\section{PIGEON HAWK FAlCO COLUMbarius}

This small falcon breeds not uncommonly in suitable places from the latitude of Haliburton District west to the west end of Lake Superior and north at least ${ }^{12}$ to Severn river on Hudson bay ${ }^{25}$. As it breeds commonly at Churchill, Manitoba ${ }^{9}$ it is likely that its nesting range includes the whole of northern as well as central Ontario.

The Pigeon Hawk of Ontario is columbarius columbarius.

Haliburton District, Haliburton-A set of five eggs is in the possession of E. Dixon.

Muskoka District, Lake Joseph-A set of four eggs taken on June 15, 1889 by 
J. D. McMurrich ${ }^{12}$ is in R.O.M.Z. as well as a set of four eggs taken on June 1, 1892.

Nipissing District, Lynx island, Temagami-A pair nested in 1930, according to A. F. Coventry.

Thunder Bay District, Whitefish lake-A set of four eggs was taken on June 15, 1929 by L. S. Dear and we obtained a set of four eggs on June 2, 1935.

L. S. Dear found another nest with four young on August 4, 1929.

\section{AMERICAN SPARROW HAWK FALCO SPARVERIUS}

The Sparrow Hawk is fairly common and well-distributed in Ontario as a breeding species, nesting at least north to Cochrane District ${ }^{31}$ and west to the southern part of the Manitoba boundary ${ }^{29},{ }^{176}$. North of this, it was found to be fairly common in the summer of 1930 along the Manitoba boundary between Lat. $53-54^{\circ} \mathrm{N}$. by D. R. Derry.

Its northern limit is probably reached at James bay ${ }^{12}$. Like many of our hawks, its numbers have been much reduced throughout most of southern Ontario.

The form visiting Ontario is considered to be sparverius sparverius.

Cochrane District-At Smoky Falls, north of Kapuskasing, adults were seen entering hole in stub on May 29, 1935 by D. A. MacLulich, and at Kapuskasing P. A. Taverner found a nest with small young on June 27, 1919.

Frontenac County, Rockwood-E. Beaupre had a set of five eggs taken by F. Forsythe on April 23, 1896.

Kent County, Fargo-Young was taken on June 6, 1901 by W. E. Saunders.

Lincoln County, St. Catharines-Pair was found nesting in 1934 by G. J. Clout.

Middlesex County, Lambeth-Set of five eggs taken on May 21, 1902 is in collection of W. E. Saunders.

Muskoka District, Port Sydney-Set of five eggs was taken on June 18, 1919 by L. L. Snyder; it is in R.O.M.Z.

Peel County, Erindale-Four young and one addled egg were found in nest (shown to J. L. Baillie) on June 27, 1926 by R. V. Lindsay. The nest was located on May 1 and contained five eggs on June 6.

Simcoe County-Set of three eggs in R.O.M.Z. was obtained on July 6,1920 by H. P. Bingham at Midhurst. At Barrie he took a set of five eggs on June 6, 1915 .

Thunder Bay District, Port Arthur-Fairly common; a set of two eggs was secured on May 30, 1907 by L. S. Dear.

York County, Toronto-Set of five eggs was taken at Cedarvale on April 12, 1929 according to C. E. Hope; H. B. Haugh secured a set of five eggs (in R.O.M.Z.) on May 31, 1916 at Forest Hill.

\section{SPRUCE GROUSE CANACHITES CANADENSIS}

The breeding ranges of the two forms of this species (canadensis canace and canadensis canadensis) which are said to occur in Ontario, have not been determined but there seems to be no doubt that the typical canadensis canadensis is characteristic of the extreme northern 
sections, while canadensis canace is the form in southern and central Ontario.

The species is not uncommon and nests ${ }^{9},{ }^{25}$ from Algonquin Park and the vicinity of ()ttawa ${ }^{23}$ northward ${ }^{19},{ }^{176},{ }^{193}$. Formerly its summer range extended somewhat farther south ${ }^{43}$ (a pair in R.O.M.Z. for example, was shot by H. Buckhan about 1908 in Caledon township, Peel (ounty).

Algoma District, near Big "U" on Upper Mississagi river, Mississagi Forest reserve-Nest with five eggs was found on May 31, 1923 by R. D. Ussher.

Cochrane District, near Kapuskasing-Flying young were seen on July 24, 1925 by R. D. Ussher.

Nipissing District, Nightingale, Peck and Hunter townships, Algonquin ParkFound with young by M. Robinson. H. P. Bingham has two eggs taken from nest by a park ranger.

Parry Sound District, Frank's bay, Lake Nipissing-Nest and six eggs found on June 1,1932 by D. A. MacLulich are in R.O.M.Z.

Sudbury District, Biscotasing-E. Dixon has a set of six eggs from there.

Thunder Bay District, Makina lake, upper Blackwater river, Lake Nipigon-A nest with five eggs was found on June 25,1924 by R. D. Ussher.

\section{RUFFED GROUSE BONASA UMBELLUS}

The Ruffed Grouse is a common ${ }^{172}$ and widely-distributed breeding resident of Ontario ranging north to the Severn river on Hudson bay ${ }^{25}$, west to Lake of the Woods ${ }^{29}$.

The form of this species in extreme southern Ontario has been called umbellus umbellus, perhaps correctly, but the race resident in the greater part of the province is umbellus togata.

Algoma District, Township 5C, Mississagi Forest reserve-One was seen with brood of young on June 27, 1923 by R. D. Ussher.

Cochrane District-Brood was seen on August 7, 1933 by A. G. Crisp and P. W. Ferris, two miles west of Fort Albany. They also saw a brood of six chicks just able to fly on July 16, 1933, at mouth of Kenogami river.

Frontenac County, Pittsburg township-Set of eight eggs was found on April 30, 1896 by E. Beaupre.

Huron County, Benmiller-Downy young in R.O.M.Z. was secured on June 7, 1935 by C. E. Hope.

Kenora District, Ontario side of Indian bay, Lake of the Woods-Bred freely in 1920 , according to letter from W. Rowan.

Muskoka District, Port Sydney-Nest and seven eggs in R.O.M.Z. was taken on May 15, 1933 by A. Kay.

Norfolk County, Woodhouse gore-Nest with twelve eggs found by J. Edmonds on May 22, 1933 is in R.O.M.Z.

Peel County, Lorne Park-Nest with fourteen eggs was seen on May 17, 1929 by D. A. MacLulich.

Sudbury District, Sylvanite lake, near Chapleau-Brood of ten young was seen on July 31,1934 by R. D. Black.

Thunder Bay District, Port Arthur-Set of eight eggs was found on May 28, 1922 by L. S. Dear. 


\section{WILLOW PTARMIGAN LAGOPUS LAGOPUS}

The Willow Ptarmigan is found as a breeding species in Ontario only along the extreme northern edge of the province, bordering James and Hudson bays ${ }^{12}, 25$ (young birds nearly full-grown were shot August 13 , 1904, forty miles south of Cape Henrietta Maria, James bay, by W. Spreadborough).

It is probably a fairly common species there in summer, as it is an abundant summer inhabitant of Churchill, Manitoba ${ }^{9}$.

A small young bird taken near Boat harbour, Great Whale river, Quebec (on the east shore of Hudson bay, just beyond the limits of Ontario) is in the collection of N.M.C.

Ontario Willow Ptarmigan are probably lagopus albus.

\section{SHARP-TAILED GROUSE PEDIOECETES PHASIANELlUS}

The Sharp-tailed Grouse is a more or less common summer resident of extreme northern and extreme western Ontario ${ }^{14}$, in the vicinity of James and Hudson bays ${ }^{12}{ }^{25}$ and in the territory lying between Lake Superior and Lake of the Woods ${ }^{44}$ (breeding in some numbers on Isle Royale, Lake Superior, Michigan, in $1904^{49}$ ).

The breeding form in the extreme north is said to be phasianellus phasianellus while the race occupying extreme western Ontario is considered to be phasianellus campestris (phasianellus campisylvicola of Snyder $\left.{ }^{179}, 1935\right)$, the two forms probably merging in north-western Ontario.

Cochrane District-A fairly common breeder in the vicinity of Portage island at the forks of the Missinabi and Mattagami rivers, according to J. C. Swartman; chicks were seen on July 24, 1925 at Twin falls, near Lake Abitibi by Mr. Seeley of the Abitibi Pulp and Paper Company.

Kenora District, north of Cobham river on Manitoba boundary, between Lat. 53-54 N.-D. R. Derry saw half-grown young on August 15, 1930.

Thunder Bay District, Port Arthur-J. H. Fleming has a specimen from there and L. S. Dear states that it breeds in some places thereabouts, but is not common.

\section{GRAY PARTRIDGE PERDIX PERDIX}

This small partridge was evidently first imported and released (one hundred brace) by the Ontario Department of Game and Fisheries ${ }^{45},{ }^{84},{ }^{85}$ in Kent and Essex Counties about 1912-14 although the earliest record of introduction ${ }^{185}$ concerns six birds released at Brantford, Brant County, in 1909 by the Brantford Fish and Game Protective Association. It has since been introduced into several counties of southern Ontario from 
Essex east to Leeds and north to Muskoka (at Huntsville, according to A. Kay) and north Frontenac (seen on March 11, 1934 by R. V. Lindsay). Its presence at Minaki in southern Kenora District is also vouched for by A. G. Lawrence of Winnipeg, Manitoba, and forty pairs were liberated in 1932 at Port Arthur, according to L. S. Dear. The birds were first propagated ${ }^{126}$ extensively by the Department in 1929 and their spread has taken place since then.

As their introduction into western Canada $^{46}$ has apparently proved successful, it seems possible that they may increase and spread throughout most of southern Ontario.

This bird has been variously called European Partridge, Hungarian Partridge, English Partridge, etc., and is probably referable to perdix perdix.

Durham County, Darlington township-Very young birds were seen in August, 1934, according to A. E. Allin.

Victoria County, Woodville-Young were seen with parents in 1934 by F. Starr.

\section{BOB-WHITE COLINUS VIRGINIANUS}

The Quail formerly occurred as a common breeding resident of southern Ontario north at least to south Georgian bay ${ }^{47}$ and east at least to Durham County ${ }^{12},{ }^{43}$ but at the present time it is very much reduced in numbers ${ }^{22}$ and is found in numbers only in the south-western counties bordering Lakes Erie and St. Clair.

The native Bob-white of Ontario is virginianus virginianus but various importations of birds from more southern localities have been made in southern Ontario and it is doubtful if our present population is subspecifically identifiable.

In Michigan ${ }^{49}$ it apparently once extended north to the southern shore of Lake Superior.

Elgin County, Aylmer-A set of eighteen eggs taken by R. T. Anderson is in R.O.M.Z.

Essex County, Point Pelee-Brood of young was seen on June 27, 1936 by J, M. Speirs.

Kent County, St. Clair frats-A set of seven eggs taken on May 21, 1889 by W. Smith is in N.M.C. ${ }^{172}$.

Middlesex County, Coldstream-Young and remnants of egg shells have been found by A. A. Wood.

Peel County, Elmbank-Formerly bred in some numbers until about 1905 according to Dr. J. McKay.

\section{COMMON PHEASANT PHASIANUS COLCHICUS}

The Pheasant is a common breeding resident of most of the more southern parts of Ontario, occurring north to southern Parry Sound District $^{110}$ and east to the vicinity of Ottawa ${ }^{113},{ }^{123}$. 
It was introduced into Ontario from Europe. Numerous liberations have taken place since $1897^{48},{ }^{136}$ and the species is firmly established in most areas south and west of Lake Simcoe. Since 1922 the Department of Game and Fisheries ${ }^{124},{ }^{125}$ has propagated and distributed birds and eggs to farmers and sportsmen in various parts of southern Ontario and so numerous have the birds become that in several counties bordering Lake Ontario, short open seasons have been declared more or less annually since 1910 .

Our pheasant is said to be colchicus torquatus.

Essex County, Pelee island-Very abundant. Set of thirteen eggs was found by us on June 4, 1933.

Huron County, Goderich-Young have been seen by C. H. D. Clarke.

Lincoln County, Niagara-on-the-lake-W. P. Young collected a single egg on May 12, 1924.

Peel County-Set of thirteen eggs was found at Dixie on May 15, 1926 by P. Harrington. These are in his collection. At Erindale J. L. Baillie saw a large brood of small young on July 5, 1934. At Summerville D. Sumner found a nest with seven eggs on May 4, 1935.

York County-Set of seventeen eggs was found at Pottageville on May 15, 1933 by S. L. Thompson. J. L. Baillie saw a nest with ten eggs at the Humber river, Toronto on May 8, 1932, and at the same place S. C. Downing discovered a nest with ten eggs on June $25,1934$.

\section{WILD TURKEY MELEAGRIS GALlopaVo}

The Wild Turkey, long since extirpated in this province, was formerly a more or less common breeding species ${ }^{143}$ in the country west and south of Durham County ${ }^{43},{ }^{147},{ }^{186}$.

Its extermination took place a few years prior to $1900^{27}$ due no doubt to the destruction of its habitat and to excessive shooting:

Archaeological evidence of the presence of Turkeys' bones in Indian refuse pits as far north as Simcoe County ${ }^{168}$ suggests that its former range in Ontario extended north and east at least to Lake Simcoe.

Native Ontario Wild Turkeys are referable to the race gallopavo silvestris.

\section{KING RAIL RALLUS ELEGANS}

This large rail occurs as a breeding species in various marshes ${ }^{27}, 130$ on Lakes St. Clair and Erie and the connecting Detroit river ${ }^{49}$.

It is not common, excepting at St. Clair flats ${ }^{12}$, and there are nonbreeding records of occurrence at various places along the southern border of the province east of Ottawa ${ }^{23}$ and north to the Bruce peninsula ${ }^{118}$, western Georgian bay.

The race of King Rail in Canada is elegans elegans. 
Lambton County, St. Anne's island, St. Clair flats-Female and set of thirteen eggs taken by W. E. Saunders in May, 1882, are in his collection.

Norfolk County, Port Rowan-Young were seen in 1921 by C. K. Rogers.

\section{VIRGINIA RAIL RALLUS LIMICOLA}

The Virginia Rail is a fairly common breeding summer resident of Ontario in favourable marshes ${ }^{23}$ north from the southern border ${ }^{141}$ to Sudbury District. It breeds commonly at Indian bay, Lake of the Woods, Manitoba ${ }^{29}$ and probably also in the Ontario part of the lake, in extreme western Kenora District and there is a record" ${ }^{214}$ of its breeding at Les Cheneaux islands, Michigan, in north-western Lake Huron.

North American Virginia Rails are called limicola limicola.

Ca:leton County, Janeville, near Ottawa-Set of nine eggs in N.M.C. was taken on May 20,1898 by A. L. Garneau ${ }^{172}$.

Frontenac County, Kingston-Set of ten eggs taken on May 27, 1898 by C. K. Clarke is in R.O.M.Z.

Grey County, Meaford-Egg in R.O.M.Z. was taken from a set of eight on July 8,1936 , by L. H. Beamer.

Lambton County, Stony point, near Port Franks-W. E. Saunders secured a set of seven eggs on May 24, 1895.

Manitoulin District, South Bay mouth-Parents were seen with five young on August 5, 1934 by J. M. Speirs.

Ontario County, Frenchman's bay - Set of eight eggs was taken on June 9, 1929 by C. E. Hope.

Simcoe County-At Barrie H. P. Bingham secured a set of ten eggs on May 5 , 1915. At Minesing, sets of five to eight eggs were found on June 7, 1927 by $\mathrm{P}$. Harrington, and broken eggs were seen by us on May 9, 1925.

Sudbury District, Bigwood-Family of adults with young was seen on June 30, 1914 by F. Starr.

Victoria County, Bobcaygeon-Set of nine eggs taken by P. Harrington on June 11, 1932 is in R.O.M.Z.

York County, Toronto-Nest with ten eggs was found on May 15, 1935 by R. Smyth at Grenadier pond (shown to J. L. Baillie on the 17th) and on July 1, 1934, six immatures were seen by J. M. Speirs and Phyllis Oughton at Humber river. Set of five eggs in R.O.M.Z. was taken on July 4, 1891 by J. L. Jackson.

\section{SORA RAIL PORZANA CAROLINA}

The Sora is a common breeder in Ontario in suitable places from the southern border ${ }^{141},{ }^{156}$ north to the west coast of James bay ${ }^{12}$ and Severn House, on Severn river ${ }^{26},{ }^{193}$ and west at least to the head of Lake Superior. Its occurrence at Churchill, Manitoba ${ }^{9}$ and Indian bay, Lake of the Woods (breeding) indicate that there is little doubt that its range includes the whole of Ontario.

Carleton County, Ottawa-Nest with twelve eggs taken by A. L. Garneau on 
May 29, 1900 and two chicks taken on June 17,1929 by R. Lockwood are in N.M.C.

Essex County, Walkerville-Set of seven eggs taken on June 2, 1875 by J. Saulliere is in R.O.M.Z.

Frontenac County, Kingston-Set of ten eggs taken by E. Beaupre on May 29, 1898 is in R.O.M.Z.

Kent County, Rondeau-We found egg in marsh on June 9, 1933.

Muskoka District, Port Sydney-Breeds, according to A. Kay.

Ontario County-Nest with eight eggs was found on June 23, 1935 by H. H. Southam at Simcoe point, Pickering. At Frenchman's bay a set of seven eggs was taken on June 1, 1923 by W. P. Young.

Simcoe County-Set of nine eggs was found on June 4, 1929 at Minesing and on June 6, 1929 a set of fourteen eggs was located at Marl lake, both by us.

Thunder Bay District, Port Arthur-Set of twelve eggs was collected on June 16, 1927 by L. S. Dear.

Victoria County, Bobcaygeon-Set of eggs was taken on June 4, 1932 by P. Harrington.

York County-Set of seven eggs was found on May 10, 1929 at Toronto, according to F. H. Emery and we saw a nest with eleven eggs there on May 29, 1926. At Maple, T. M. Shortt showed J. L. Baillie a nest with seven eggs on May 29, 1932.

\section{YELLOW RAIL COTURNICOPS NOVEBORACENSIS}

Hutchins (quoted by Macoun ${ }^{12}$ ) states that this rail bred near the efflux of Severn river on Hudson bay about 1777 .

We are not aware of any further definite nesting data for the province but the bird has been watched in the breeding season at various locali$\operatorname{ties}^{43},{ }^{187}$ between Lake St. Clair and James bay within recent years.

It is possible that the species may breed in suitable marshes anywhere in the province, as there are records of nesting to the east, west and south of Ontario ${ }^{26}$, half-grown young having been taken by Hicks ${ }^{207}$ on August 9, 1932 in Ashtabula County, Ohio, on the south shore of Lake Erie.

Cochrane District, Moose Factory-S. Waller assures us that D. Sailless, Indian at Moose Factory, claims to have once found a nest of this rail "containing many eggs" and there is a specimen in R.O.M.Z. secured there by Waller on June 2, 1930.

\section{COMMON GALLiNULE GALLinUla CHLOROPUS}

The Gallinule is a fairly common summer inhabitant of the larger marshes of extreme southern Ontario ${ }^{141}$ breeding north at least to south Georgian bay and Ottawa ${ }^{23}$. The most northern record of its occurrence is at the mouth of Sturgeon river, Lake Nipissing, where one (in R.O.M.Z.) was obtained about 1921 by Dr. F. W. McKee.

The North American Common Gallinule is chloropus cachinnans. 
Durham County, Orono-Nest with nine eggs was found on June 9, 1935 by R. A. Smith.

Essex County-Two chicks taken at Point Pelee on June 11, 1913, by P. A. Taverner, are in N.M.C. I. Maharg took a set of eight eggs on May 31, 1903 at "Detroit river, Ontario".

Frontenac County, Kingston-Set of twelve eggs taken on May 28, 1898 by C. K. Clarke, is in R.O.M.Z. J. L. Baillie and R. O. Merriman saw adults with five young in the marsh on July $24,1930$.

Kent County, Mitchell's bay-Set of four eggs in R.O.M.Z. was secured by K. Doan June 22-26, 1935.

Lanark County, Smith's Falls-Downy young, taken on July 12, 1918 by P. A. Taverner, is in N.M.C.

Leeds County, Lansdowne-E. Beaupre and C. J. Young found a nest with one egg on June 10, 1896.

Ontario County, Port Whitby-Two families were seen in July, 1934 by H. K. Gordon.

Peterborough County, Lakefield-Egg in R.O.M.Z. was secured about 1914 by A. M. Fitzgerald.

Simcoe County-Set of nine eggs in R.O.M.Z. was found by H. B. Haugh on June 2, 1918 at Little lake. At Marl lake we found a nest with nine eggs on June 5, 1928 and a set of nine eggs in R.O.M.Z. was taken near Barrie on July 2, 1917 by H. B. Haugh.

York County, Humber marsh, Toronto-Nest with ten eggs was seen on May 22 1915 by $\mathrm{P}$. Harrington and adult was seen with rather small young by J. L. Baillie on July 5, 1934. On August 18, 1935 J. L. Baillie saw parents with five half-grown young.

\section{AMERICAN COOT FULICA AMERICANA}

The Coot breeds irregularly throughout the marshes of southern Ontario ${ }^{143}$ (more common formerly in certain places ${ }^{49}$ ) north and west to Thunder Bay district and probably to Lake of the Woods ${ }^{29}$ and Sudbury District ${ }^{16}$. Its northern limit of occurrence is Moose Factory on James bay, where one was obtained by S. Waller (in R.O.M.Z.) in 1926. It is unaccountably absent from many of the larger and apparently suitable marshes within its range. The North American Coot is americana americana.

Muskoka District, Port Sydney-Breeds, according to A. Kay.

Norfolk County, Long Point-J. Savage saw an adult with several young on July 4,1930 .

Ontario County, Frenchman's bay-A set of ten eggs was taken by W. P. Young on May 20, 1917.

Simcoe County, Little lake, Barrie-A set of seven eggs was taken on June 16, 1918 , by H. P. Bingham.

Thunder Bay District, Whitefish lake-Set of eight eggs and set of seven eggs were taken on May 25, 1931, by L. S. Dear.

York County, Toronto ${ }^{167}$ - Set of eight eggs taken at Ashbridge's bay on July 12, 1890 , by J. L. Jackson, is in R.O.M.Z. Brood of ten small young was seen 
on Humber marsh on June 14, 1932 by J. L. Baillie; nest with four eggs was found in Humber marsh on June 3, 1911 by C. G. Harbour, and nest with seven eggs on May 31,1936 , by R. A. Smith.

\section{PIPING PLOVER CHARADRIUS MELODUS}

The Piping Plover nests more or less commonly on the beaches bordering Lake Erie ${ }^{156},{ }^{205}$, Lake Ontario, Lake Huron and southern Georgian bay, as well as along the Ontario part of the St. Lawrence river.

It likely breeds also in the vicinity of Lake of the Woods in extreme western Ontario, as it is a nesting species in Manitoba ${ }^{12},{ }^{29}$ and has been found in July on the southern Manitoba-Ontario boundary.

Essex County-Set of two eggs was found on Pelee island on June 5, 1933 by E. M. S. Dale and W. E. Saunders has two sets of two eggs taken at Point Pelee on May 24, 1906.

Lambton County, Ipperwash beach, east of Kettle point-Young were found in July, 1928, by W. E. Saunders.

Leeds County, near Rockport-Set of two eggs found on June 18, 1894 by C. J. Young, is in N.M.C.

Norfolk County, Turkey Point-Set of four eggs was found about May 30, 1924 by G. W. Knechtel.

Simcoe County, Wasaga Beach-Set of four eggs was found on May 20, 1934, by O. E. Devitt and on June 20,1913, P. Harrington found four young which had just hatched.

Wentworth County, Hamilton-Nest was seen at Van Wagner's beach in June, 1934, by G. W. North.

York County, Toronto-Two sets of four eggs were seen at Fisherman's island on May 24, 1928 by J. L. Baillie and three downy young and one egg were secured from a nest by G. H. Richardson at Hanlan's point on June 9, 1934 .

\section{SEMIPALMATED PLOVER CHARAdRIUS SEMIPALMATUS}

This plover is confined, as a breeding bird in Ontario, to the extreme northern sections of the province bordering James and Hudson bays.

It was found by Spreadborough ${ }^{12}$ to be common in July, 1904, on the west coast of James bay (young still unable to fly on the 7 th) and since it is an abundant breeding species at Churchill, Manitoba ${ }^{9}$, it seems probable that it nests in numbers all along the coast between these points.

\section{KILLDEER PLOVER OXYECHUS VOCIFERUS}

The Killdeer is a fairly common nesting species of Ontario from Lake Ontario and Lake Erie west to Thunder Bay and Kenora Districts ${ }^{29}$ and north to the southern end of James bay. It breeds regularly also at Churchill, on Hudson bay ${ }^{9}$ and it is conceivable that its breeding range 
includes the whole of the province of (Ontario, as it has been found breeding also at Lake of the Woods, in southern Manitoba.

Cntario Killdeers are vociferus vociferus.

Cochrane I)istrict-At Moose Factory a set of four eggs (in R.O.M.Z.) was found on May 26, 1930 by S. Waller and E. Dixon has eggs taken at Lake Abitibi by A. V. Dukes.

Elgin County, Port Burwell-A set of four eggs was taken on May 13, 1924 by F. Starr.

Frontenac County, Kingston-A set of four eggs taken on April 16, 1902 by E. Beaupre is in R.O.M.Z. Another set of three eggs in R.O.M.Z. was found by Beaupre on July 11, 1897 and on May 14, 1922 he found a nest with four downy young.

Hastings County, Stirling-Nest with four eggs was found on June 11, 1926 by E. W. Calvert.

Kenora District, Kenora-Set of three eggs was found on June 7, 1931 by L. Paterson, according to B. W. Cartwright.

Lincoln County, Port Weller-Set of four eggs was found by G. J. Clout on April 16, 1933.

Parry Sound District, Pickerel lake, east of Burk's Falls-A set of four eggs was seen by J. L. Baillie on July 11, 1936.

Simcoe County - Set of four eggs was taken on July 2, 1923 by P. Harrington at Collingwood and at Vespra township H. P. Bingham took a set of four eggs on May 8, 1923 (in R.O.M.Z.).

Thunder Bay District-At Port Arthur a set of four eggs was found on June 4,1914 , by L. S. Dear; at Peninsula, a brood of four young, in R.O.M.Z., was secured on June 21, 1936, by C. E. Hope.

York County, Toronto-Set of four eggs was photographed by us at Sunnyside on April 19, 1924. A set of four eggs in N.M.C. was taken at Centre island by L. B. Brown on June 23, 1909.

\section{AMERICAN WOODCOCK PHILOHELA MINOR}

The Woodcock is a well-distributed summer resident in southern ${ }^{45}$ and eastern ${ }^{23}$ Ontario, breeding in very much reduced numbers north at least to Temagami Forest reserve, and Renfrew County.

Its presence in August, 1860 at Sault Ste. Marie and Mississagi (southern Algoma District) has been recorded by Bell1 ${ }^{184}$.

Hastings County, northern part-E. Beaupre saw set of eggs taken on May 20, 1919.

Kent County, Merlin-Downy young in the collection of J. H. Fleming was taken on May 11, 1901 by G. E. Atkinson.

Middlesex County, Plover Mills-W. E. Saunders has a set of four eggs taken on April 14, 1890.

Muskoka District, Port Sydney-Two young were seen in August, 1931, by L. J. Payne.

Nipissing District-Nest with two eggs was photographed at Sandy inlet, Temagami on May 24, 1929 by J. M. Gardner. A nest with four eggs was shown to W. E. Ricker by C. Ramsay at North Bay on June 8, 1926.

Ontario County, Thorah island, Lake Simcoe-Brood of four young, just hatched, 
was found on April 25, 1929 by J. A. Edwards, who also found a set of four eggs on June 6, 1930.

Peel County, Cooksville-Nest with four eggs found on May 4, 1930 by W. Brown, was photographed on the 7th by A. R. Van.

Renfrew County, Renfrew-Seen on nest by E. Coxwell in 1899, according to journals of J. H. Samuel.

Simcoe County, Wasaga Beach-Brood of three young was found on May 20, 1922 by P. Harrington. These were approximately one week old.

York County-Nest with two hatched eggs was seen on May 12, 1933 at Islington by J. L. Baillie; three young were banded at Pottageville on July 7, 1932 by C. H. D. Clarke. J. Townson found a nest with three eggs in High Park on April 9, 1925.

\section{WILSON'S SNIPE CAPELla DELICATA}

The Wilson's Snipe undoubtedly nests in suitable marshy habitat throughout the whole of Ontario as it has been found breeding at various places between Lake Erie and Hudson bay ${ }^{9},{ }^{12}$ (Cape Henrietta Maria, northern James bay).

It is apparently absent from large $\operatorname{areas}^{18},{ }^{31}$ in northern Ontario, possibly due to the lack or scarcity of proper habitat.

Cochrane District, Moose Factory-Bred on Moose island, according to S. Waller

Elgin County, Port Stanley-At least four nests with eggs have been found by N. T. Jones.

Lincoln County, St. Catharines-Adult was seen with young on June 15, 1935 by G. J. Clout.

Middlesex County, 12 miles north of Strathroy-Few pairs nest nearly every year, according to A. A. Wood.

Muskoka District, Port Sydney-Breeds, according to A. Kay.

Parry Sound District, near Katrine-Breeds, according to R. J. Rutter.

Simcoe County-Nest with four eggs was collected by P. Harrington on June 10, 1928 at Cranberry lake; at Minesing P. Harrington and F. Starr found a nest with three eggs on June 7, 1927, and at Marl lake O. E. Devitt located a nest with four eggs on May 25, 1936.

Thunder Bay District, Port Arthur-Set of four eggs was taken on May 22, 1935 by L. S. Dear.

York County, Toronto marsh-Used to breed regularly, according to C. W. Nash.

\section{UPLAND PLOVER BARTRAMIA LONGICAUDA}

Along the southern border of Ontario ${ }^{131},{ }^{159}$ as far east as Dundas ${ }^{51}$ and Stormont ${ }^{113}$ Counties and as far north as Simcoe and Victoria Counties, this species is a regular but not common breeding summer resident.

Its nesting more or less commonly in parts of southern Manitoba ${ }^{44}$ would strengthen the theory that it breeds in parts of extreme western Ontario, about Lake of the Woods, but definite data are lacking.

Brant County, Brantford-Nest was found in a hayfield, by H. Fulcher. 
Elgin County, Aylmer-W. E. Saunders has a set of four eggs taken on May 29, 1895 by R. T. Anderson.

Frontenac County-Set of three eggs was taken by E. Beaupre on June 25, 1896, at Simcoe island. At Kingston, he collected a clutch of four eggs on May 12 1895 (both in R.O.M.Z.).

Peel County-Adults were seen with one young on July 2, 1933 by C. E. Hope at Brampton. At Lakeview, O. E. Devitt saw nest with four hatched eggs on June 23, 1935.

Simcoe County, Midhurst-Young bird was seen on June 29, 1935 by P. Harrington.

Victoria County, near Bobcaygeon-Young and nest with hatched eggs were seen on June 29, 1930 by F. Starr.

York County-At $2 \frac{1}{2}$ miles west of Lansing, partly-grown young was seen with its parent on July 17, 1932 by T. F. McIlwraith, and a nest with four eggs, found at Islington by D. Sumner on May 31, 1936, contained three young and one egg on June 3 , according to S. L. Thompson.

\section{SPOTTED SANDPIPER ACTITIS MACULARIA}

This widely distributed species is found throughout Ontario ${ }^{156}$ being one of the few birds which nest commonly in all parts of the province ${ }^{12},{ }^{176}$.

Algoma District-At Mississagi Forest reserve, a nest with two eggs was found on May 30, 1923 by R. D. Ussher; at Amyot, S. C. Downing took a set of four eggs on June 27, 1936 (in R.O.M.Z.)

Cochrane District-Nest and four eggs in R.O.M.Z. were found on June 19, 1935 by R. V. Whelan at Smoky Falls, north of Kapuskasing, and E. Dixon has eggs taken at Lake Abitibi by A. V. Dukes.

Essex County, Point Pelee-Set of four eggs taken on June 2, 1913 is in collection of W. E. Saunders.

Kenora District, Kenora-Nest with four eggs was found on June 18, 1930 by L. Paterson.

Lennox and Addington County, Amherst island-E. Beaupre found a set of four eggs on May 24, 1922.

Lincoln County, St. Catharines-Set of four eggs was found by G. J. Clout on June 3, 1934.

Manitoulin District, McGregor bay-Set of four eggs taken on June 11, 1925 and set of four eggs taken on June 22, 1924 by B. A. Bensley are in R.O.M.Z.

Muskoka District, Port Sydney-Egg taken on May 20, 1926 and downy young taken on July 10,1900 by A. Kay are in R.O.M.Z.

Ontario County-Nest with three young and one egg was shown to J. L. Baillie at Pickering on July 15, 1928 by W. B. Edmonds. At Thorah island, Lake Simcoe, P. Harrington took a set of four eggs on June 7, 1914.

Thunder Bay District, Port Arthur-Set of four eggs was found on June 10. 1922 by L. S. Dear.

\section{SOLITARY SANDPIPER TRINGA SOLITARIA}

The eggs of this species have not been found in Ontario. There are a few records, however, of the bird being seen with small downy young ${ }^{12},{ }^{23},{ }^{41},{ }^{188}$ and many records of its occurrence at breeding time 
in various sections of the province ${ }^{31},{ }^{39}$ and it probably nests regularly in many parts of central and northern Ontario. The summer resident form in the extreme north-western sections may be solitaria cinnamomea ${ }^{9}$ but our form is usually considered to be solitaria solitaria.

\section{LESSER YELLOW-LEGS TOTANUS FLAVIPES}

The only record of this species nesting in the province is that of Spreadborough ${ }^{12}$ who found it in the summer of 1904 on the west coast of James bay (young flying early in July).

Like many other shore-birds, the Lesser Yellow-legs breeds commonly at Churchill' $^{9}$ (to the north-west of Ontario on Hudson bay) and it is more than likely that it nests in some numbers along the extreme northern "sea-coast" of Ontario.

\section{WILSON'S PHALAROPE STEGANOPUS TRICOLOR}

There are but two known nesting stations for this species within the boundaries of Ontario, one at Dunnville, Haldimand County ${ }^{53}$, ${ }^{143}$ (nest with three eggs found on June 9, 1879 by G. A. McCallum) and the other at Dunwich, Elgin County (in 1934 and 1935). Both of these counties are on the north shore of Lake Erie.

As the Wilson's Phalarope is a western species, breeding regularly in Manitoba, its summer occurrence and possible breeding might be expected in the area about Lake of the Woods but the two known nesting places might be considered extralimital, although Barrows ${ }^{49}$ cites an old record of its breeding near Ann Arbor, southern Michigan.

Elgin County, Dunwich swamp, West Lorne-Nest, which contained three downy young and one hatched egg, was found by E. Lemon on June 10, 1934. The nest, egg and photograph of the downy young are now in R.O.M.Z. In 1935 they again nested there, according to J. M. Speirs, and they returned again in 1936 , according to G. H. Richardson.

\section{HERRING GULL LARUS ARGENTATUS}

The Herring Gull is the commonest and most widely-distributed of the breeding gulls of Ontario, nesting colonies having been examined from the southern border ${ }^{207}$ (young found in 1926 on Big Chicken island, Essex County, at west end of Lake Erie) north to Lake Abitibi ${ }^{31}$ and west $^{176}$ to the Manitoba boundary in southern Kenora District. It is most common about the larger lakes in central Ontario and there is no reason to doubt that it nests northward and westward ${ }^{9}$ throughout the province as Murray records ${ }^{193}$ the species from Severn House, on Severn river.

Our form is said to be argentatus smithsonianus. 
Cochrane District-At Bank's lake, Staples township, near Kapuskasing, three nests with two and three eggs were found on a small island on June 16 , 1925 by R. D. Ussher. E. Dixon has a set of two eggs from Lake Abitibi.

Frontenac County, Salmon and Snake islands off Kingston-In 1928 one nest was found on each island and in 1929 three nests were found on Snake and one on Salmon island by E. Beaupre.

Kenora District, Lake Gordon, McIntosh-Downy young were seen on June 21, 1933 by G. W. Kelly, according to A. G. Lawrence.

Lennox and Addington County-Egg taken at Mazinaw lake on May 20, 1934 by R. E. Akey, is in R.O.M.Z. In 1928 a nest with eggs was found on one of the Three Brothers islands (off Kingston) by E. Beaupre.

Muskoka District, Watcher's islands, Go Home Bay-Colony was found nesting on June 30,1923 by S. L. Thompson.

Nipissing District-Eggs were found on June 17, 1928 by A. F. Coventry at Temagami. J. O. Gilchrist photographed a nest with three eggs on May 24, 1928 at Eagle lake, Algonquin Park. Nests with eggs were found on June 23, 1929 by W. E. Ricker at Goose island, Lake Nipissing.

Parry Sound District, Horne lake, Burk's Falls-E. Dixon has a set of two eggs.

Thunder Bay District, Port Arthur-Large breeding colony was visited on May 25, 1913, by L. S. Dear, who also collected a set of three eggs on May 28, 1930 (in R.O.M.Z.).

Victoria County, Sturgeon lake-Nest was found in June, 1931, by A. E. Allin, F. Starr and P. Harrington.

\section{RING-BILLED GULL LARUS DELAWARENSIS}

This gull is a common nesting bird in the Georgian Bay region and in parts of adjoining Lake Huron ${ }^{157}$ in which places it associates, to some extent, with the Herring Gull on small rocky islands. It is known to breed in only one other section of the province, at Salmon island on Lake Ontario, although there are more or less ancient records of its breeding in Victoria and Lennox and Addington Counties ${ }^{12}$ and on the north shore of Lake Superior ${ }^{14}$ none of which corresponds to observations of present-day observers.

Frontenac County, Salmon island-On May 27, 1927 two nests with two eggs were found; in 1928 eighteen pairs hatched out their young and in 1929 the colony had increased to eighty -four pairs, according to E. Beaupre.

Muskoka District, South Watcher islands, Go Home Bay-A young bird in R.O.M.Z. was taken by R. T. Anderson on August 2, 1902; on June 16, 1912 T. Glasgow collected eggs, according to P. Harrington and on June 17, 1923, eggs were taken by B. A. Bensley which are now in R.O.M.Z.

Parry Sound District, Limestone islands, off Parry Sound-About 500 nests were found on June 12, 1916 by C. J. Young and on June 18, 1918, 57 nests (all with eggs) were examined by $\mathrm{E}$. Beaupre.

\section{COMMON TERN STERNA HIRUNDO}

The Common Tern nests commonly, in colonies, on many of the larger lakes of the province from Lake Erie ${ }^{156}$ and the eastern end of 
Lake Ontario, north at least to Lake Abitibi ${ }^{31}$ and west to the Manitoba boundary (Lat. $53-54^{\circ} \mathrm{N}$.). The northern limits of its breeding range are undetermined ${ }^{12}$ (one in R.O.M.Z. was taken at Moose Factory on June 7,1928 by S. Waller) but there is every likelihood that it is replaced along the northern coast of Ontario by the Arctic Tern, Sterna paradisaea.

North American Common Terns are hirundo hirundo.

Cochrane District, Bank's lake, Staples township, near Kapuskasing-Twelve nests with one, two and three eggs were found on June 16,1925 by R. D. Ussher, on a small island in the lake.

Essex County, Pelee island-A colony found by F. H. Emery on June 26, 1932, contained 205 sets of eggs when visited by us June 3-5, 1933.

Frontenac County, Salmon island-About 600 pairs nested in 1929 according to E. Beaupre, who states that they were first found nesting there by him in 1895. A set of three eggs in R.O.M.Z. was taken by Beaupre on June 6, 1898 .

Haldimand County, near Lowbanks-Young were seen in a colony on July 8, 1935 by J. M. Speirs.

Kenora District-Found breeding on an island in Lac Seul in 1919 by D. Blakely; fully grown young, taken on July 31 , are in N.M.C. Eggs were seen in June, 1930 by D. R. Derry between Lat. $53-54^{\circ}$ on the Manitoba boundary.

Kent County, Rondeau-Twenty-three nests were occupied about July 11, 1934 according to J. H. Smith.

Lennox and Addington County, Amherst island-Four nests with eggs were found by E. Beaupre on July 28, 1905 and on August 29, 1917 he saw three small chicks. On June 9, 1922 fully 250 pairs were breeding there, and 168 nests with eggs were counted, according to Beaupre.

Nipissing District, Lake Nipissing-Large colony was breeding on Goose islands on June 30, 1929 according to W. E. Ricker, the nests containing one to four eggs.

Simcoe County, Collingwood-Small colony was found nesting on July 2, 1923 by P. Harrington (set of three eggs in R.O.M.Z.).

York County, Little Sandy island, off Virginia, Lake Simcoe-Forty-three pairs had eggs on June 24,1934 , when the colony was visited by R. A. Smith and J. L. Baillie. The breeding-place was discovered in July, 1931 by G. H. Johnston.

\section{CASPIAN TERN HYDROPROGNE CASPIA}

This large tern is known to nest in Ontario at only four localities, at Limestone islands off Parry Sound on the east shore of Georgian bay ${ }^{54}$, at Salmon island at the east end of Lake Ontario ${ }^{55}$ and at the two additional localities mentioned below. It is not a common species, but at Limestone islands there is a colony of upwards of one hundred and fifty pairs.

Other nesting-places may exist in Georgian bay and Lake Huron and possibly elsewhere, in suitable places, and there is a specimen in R.O.M.Z. taken by S. Waller at Moose Factory on May 31, 1928. 


\section{Our form is caspia imperator.}

Manitoulin District, Gull island, off east coast-A small colony of about ten pairs was visited in 1933 and 1935 by W. I. Lyon. In addition, there is recorded ${ }^{172}$ a set of two eggs in N.M.C. "said to have been taken on Sewell island, west of Manitoulin island July 2, 1891".

Parry Sound District, Limestone islands, off Parry Sound-A set of two eggs in R.O.M.Z. was taken on June 12, 1916 by C. J. Young.

York County, small island off Virginia, Lake Simcoe-An egg of this species was found in a colony of Common Terns on June 24, 1934 by R. A. Smith and J. L. Baillie. A single Caspian tern, with dozens of its smaller relatives, hovered over the observers. The large egg was hatched but no sign of others, or a nest, could be found.

\section{BLACK TERN CHLIDONIAS NIGRA}

The Black Tern is a common summer inhabitant of extreme southern Ontario ${ }^{141}$, nesting in many of the marshes north to Georgian bay and probably to southern Algoma District (breeding at Manuscong bay, Michigan ${ }^{213}$ in northern Lake Huron).

The only breeding stations north of Georgian bay are near Fort Albany on James bay ${ }^{12}$ and in the vicinity of the Cobham river between Lat. $53-54^{\circ}$ on the Manitoba boundary but as the species breeds locally at Churchill on Fiudson bay ${ }^{9}$ and also at Lake of the Woods, Manitoba ${ }^{29}$ it is probable that Black Terns occupy suitable marshes throughout the province. We saw one on June 8, 1935 at Whitefish lake, near Port Arthur and Murray ${ }^{193}$ records the species from Moose Factory and Severn House, on Severn river.

North American Black Terns are nigra surinamensis.

Essex County-Set of three eggs collected at Point Pelee on June 5, 1913 by P. A. Taverner ${ }^{156}$ is in N.M.C. J. C. Wood took a set of three eggs on June 9, 1901 (in R.O.M.Z.) on Grassy island, Detroit river.

Frontenac County, Kingston-Set of two eggs was taken on May 21, 1916 by P. Harrington. On June 19, 1897, H. M. Clarke took a set of three eggs (in R.O.M.Z.).

Kenora District, Cobham river (Lat. $53-54^{\circ}$ ) on the Manitoba boundary-Often seen during the summer of 1930 and flying young were noted in late July by D. R. Derry.

Kent County, Jeanette's creek-A set of three eggs in R.O.M.Z. was taken on June 13,1898 by $\mathrm{H}$. Gould.

Leeds County, Lansdowne-Nest with three eggs was found on June 10, 1896 by C. J. Young and E. Beaupre.

Norfolk County, Long Point-Set of three eggs in R.O.M.Z. was taken on June 9, 1932 by A. F. Coventry.

Ontario County, Frenchman's bay-On June 10, 1928 a set of two eggs was found by R. V. Lindsay and C. E. Hope.

Simcoe County-Set of two eggs was taken on May 20, 1922 by P. Harrington 
at Marl lake and a set of three eggs in R.O.M.Z. was taken at Little lake on June 24,1917 by $\mathrm{H}$. B. Haugh.

Victoria County, Lake Scugog-Sets of eggs were found near mouth of Scugog river on June 2, 1931 by P. Harrington, F. Starr and A. E. Allin.

York County, Ashbridge's bay, Toronto-Numbers formerly bred in the marsh, according to J. Townson.

\section{MOURNING DOVE ZENAIDURA MACROURA}

The Mourning Dove is a common breeding species in the extreme southwestern section of the province, in some places large numbers nesting in colonies containing more than three hundred occupied nests ${ }^{106},{ }^{189}$.

To the north it is less common and the northern limits of its breeding range are reached in Simcoe and Carleton Counties ${ }^{23}$ although they have been known to occur at various places ${ }^{95},{ }^{155}$ north to James bay (one in R.O.M.Z. was secured at Moose Factory by S. Waller on September 11, 1929) and west to the Manitoba boundary ${ }^{9}$. Barrows ${ }^{49}$ states that it breeds in Alger county, Michigan, on the south shore of Lake Superior.

Our Mourning Dove is probably macroura carolinensis.

Durham County, Hampton-Set of two eggs in R.O.M.Z. was found on April 30, 1927 by A. E. Allin.

Essex County - Several sets of two eggs were examined by us on Pelee island on June 5, 1933. On June 6,1932, upwards of two hundred occupied nests were seen by H. H. Southam and J. L. Baillie at the Miner sanctuary, Kingsville.

Frontenac County, Kingston-Adults were seen feeding two young on July 27, 1923 by E. Beaupre.

Hastings County, near Trenton-Set of two eggs taken on May 10, 1921 by W. H. Lunn is in R.O.M.Z.

Huron County, West Wawanosh township-Nest and set of two eggs taken on July 14, 1935 are in possession of S. C. Downing.

Lincoln County, St. Catharines-Nest with two young was found on September 15,1935 by G. J. Clout, and two nests with two eggs on May 31,1935 by the same observer.

Peel County, Erindale-Several young were seen by R. V. Lindsay on June 22, 1930.

Simcoe County-Nest with two young was found on June 3, 1928, at Collingwood; nest with two young at Orr lake on June 7, 1929 and nest at Mac on June 9,1929 , all by us.

Waterloo County, Haysville-Nest with two young was found on July 13, 1935 by R. D. Ussher.

Wentworth County, Stony creek-Adult was watched brooding two young (nearly ready to fly) on September 30, 1935 by G. W. North.

\section{PASSENGER PIGEON ECTOPISTES MIGRATORIUS}

The passenger pigeon has been extinct since about 1900 . It was once an abundant summer resident of Ontario, breeding in large rookeries 
throughout the province, especially in the more southern and central parts.

Their breeding distribution, however, extended north at least to Moose Factory on James bay"1, $4,{ }^{172}$ and west to Lake of the Woods.

A recent work on this species in Ontario ${ }^{169}$ by Margaret $\mathrm{H}$. Mitchell contains a full account of the history of this bird in the province.

\section{YELLOIV-BILLED CUCKOO COCCYZUS AMERICANUS}

The Yellow-billed Cuckoo is a moderately common nesting species in parts of extreme southern Ontario.

Its breeding range extends north at least to Rosseau (Parry Sound District $)^{39}$ and possibly to southern Algoma District ${ }^{95}$ and east to Renfrew County $y^{12}$ but it is a comparatively rare bird in all but the Lake Erie region of this province.

The Yellow-billed Cuckoo of eastern Canada is americanus americanus.

Kent County, Rondeau-Set of two eggs was found by us on June 12, 1933.

Lincoln County, near St. Catharines-A nest with two eggs was found on June 27, 1936 by G. J. Clout.

Middlesex County, seven miles west of London-Set of five eggs was taken on June 7, 1902 by W. E. Saunders.

Peel County, Erindale-A young bird, just out of the nest, found on June 24, 1934 , was shown to H. M. Halliday and J. L. Baillie on the 27 th by H. R. Ivor.

Victoria County, Bobcaygeon-Nest with three eggs was found by us on June 11, 1932 ; the nest is in R. O. M. Z.

Waterloo County, Haysville-Nest with two young was found on July 13, 1935, by R. D. Ussher.

Wentworth County, Hamilton-Nest with three half-feathered young was found on August 9,1934 by G. W. North.

York County - Nest with two eggs and one young was found at Toronto on August 3, 1914 by F. Starr; on June 17, 1929, R. D. Ussher found a nest with one egg near King.

\section{BLACK-BILLED CUCKOO COCCYZUS ERYThRopthalMUS}

This cuckoo is a fairly common and much more widely-distributed summer resident than the preceding species.

It breeds north at least to Parry Sound and southern Thunder Bay Districts (and probably southern Kenora ${ }^{29}$ District, as one was seen at Kenora on June 10, 1932 by L. S. Paterson). It is known to breed in Roseau and St. Louis Counties, Minnesota ${ }^{176}$ adjacent to Rainy River District, Ontario.

Elgin County, Union-Flightless young albino in R.O.M.Z. was picked up by

T. N. Jones on September 16, 1935 and received from R. W. Johnson of St. Thomas. 
Frontenac County, Kingston-Set of five eggs was taken on June 4, 1901 and set of three eggs (in R.O.M.Z.) on May 30,1900 by E. Beaupre.

Halton County, Twelve-mile creek-Nest with three young was found on June 26, 1926 by T. F. McIlwraith and J. L. Baillie.

Lincoln County, St. Catharines-A set of three eggs was found on May 27, 1936 by G. J. Clout.

Muskoka District, Port Sydney-Set of two eggs in R.O.M.Z. was taken on June 27,1919 by L. L. Snyder.

Parry Sound District-Nestlings taken at Lake Rosseau in August, 1888 are in the collection of J. H. Fleming. J. M. Speirs found one on nest at Spring lake, near Sundridge, on August 5, 1926.

Simcoe County-Set of three eggs was found by us on June 8, 1929 at Marl lake. At Wasaga Beach on August 13, 1933 a nest with two eggs was examined by O. E. Devitt.

Thunder Bay District, Port Arthur-Set of three eggs was taken on July 12, 1931 by L. S. Dear.

Victoria County, Bobcaygeon-Set of two eggs was taken on July 2, 1925 by F. Starr.

York County, Toronto-Set of two eggs in R.O.M.Z. was taken on August 16, 1889 at Rosedale by J. L. Jackson; flightless young were seen at Ashbridge's bay by A. E. Allin on August 19, 1933; set of three eggs was taken on May 30,1915 by $\mathrm{F}$. Starr.

\section{AMERICAN BARN OWL TYTO ALBA}

This southern owl is a rare resident of lower Ontario. It has occurred a number of times at various localities north to Algoma District ${ }^{5}$ and Lake of the Woods (Minnesota) ${ }^{176}$ and east to Frontenac County ${ }^{56}$ and Ottawa ${ }^{117}$ but there are records of its nesting at only four localities, two in $\mathrm{Kent}^{57}$, one in Essex, and one in Middlesex ${ }^{116}$.

North American Barn Owls are probably aiba pratincola.

Essex County, Kingsville-Nest with 2 young and 2 eggs was found in June, 1936, according to W. E. Saunders.

Kent County, five miles south of Chatham-Nest with five young was found in barn in the summer of 1932 by J. H. Smith; the nest, containing four large young, was shown to us on June 11,1933 , when one of the occupants was photographed and collected for R.O.M.Z.

\section{AMERICAN SCREECH OWL OTUS ASIO}

This is probably the most common of the nesting owls of extreme southern Ontario, breeding from the southern border north to Muskoka and Carleton Counties ${ }^{23},{ }^{188}$. Records of its residence in Parry Sound District ${ }^{12}$ would indicate that it nests farther north than is known at present. Thompson ${ }^{44}$ cites a record of its presence at Saboskong bay, Lake of the Woods, possibly in error.

Our Ontario form is said to be asio naevius. 
Brant County, Homedale - Set of four eggs taken on May 5, 1918 is in possession of F. Starr.

Essex County-Young in nest were seen by us at Pelee island on June 4, 1933.

W. E. Saunders has a set of four eggs taken at Point Pelee on April 27, 1918.

Frontenac County, Kingston-Set of five eggs, found on April 21, 1926 by E. Beaupre, is in R.O.M.Z. Beaupre also found a nest with five young on May 20, 1924.

Kent County, Rondeau-Four young were seen out of the nest on June 7, 1933, by us.

Muskoka District, Port Sydney-Breeds rarely, according to A. Kay.

Peel County, Dixie - Set of four eggs was found on April 27, 1929 by P. Harrington.

Simcoe County, Wasaga Beach-Five young, just out of nest, were seen on July 17,1920 by P. Harrington.

Victoria County, Woodville-Set of five eggs was found by P. Harrington on May 7, 1932 and a set of three eggs in R.O.M.Z. was taken there by Harrington on June 5, 1932.

Waterloo County, Kitchener-Adult and six young in nest were banded by G. W. Knechtel May 15-18, 1928.

York County-J. A. Edwards took a set of three eggs on March 23, 1927 at Kleinburg and W. P. Young collected a set of four eggs at Highland creek on May $25,1910$.

\section{GREAT HORNED OWL BUBo VIRGINIANUS}

- The Great Horned Owl occurs at least from the southern border of Ontario north to southern Cochrane District ${ }^{12},{ }^{58}$ and west to Thunder Bay District ${ }^{19}$ (and probably to Lake of the Woods ${ }^{29},{ }^{176}$ ) and it was noted commonly in the summer of 1930 by D. R. Derry on the Manitoba boundary between Lat. $53-54^{\circ} \mathrm{N}$. It is a fairly common breeding resident species.

The form of this species in northern and western Ontario is considered by Taverner to be virginianus subarcticus, while the race in southern Ontario is said to be virginianus virginianus. If there are two forms breeding in the province, their respective ranges have not been determined ${ }^{180}$.

Algoma District, Bachawana bay-Two well-grown young were seen on July 12, 1935 by C. H. D. Clarke.

Cochrane District, Smoky Falls, north of Kapuskasing-Nest was found (young close by) by R. V. Whelan on July 22, 1933 and juvenile taken on June 15, 1933 by Whelan is in R.O.M.Z.

Frontenac County, Murvale-Three young were found in nest on April 8, 1906 by E. Beaupre.

Leeds County, Gananoque-Nest with two young (one dead also under nest) was found on April 26, 1935 by G. C. Toner.

Ontario County-Set of three eggs was taken on February 27, 1931 by J. A. Edwards at Thorah island, Lake Simcoe. At Glen Major, T. M. Shortt saw a nest with two young on April 20, 1935. 
Parry Sound District, Doe lake-Set of three eggs was taken on March 28, 1909 by E. S. Norman, according to P. Harrington.

Peel County, Meadowvale-Set of two eggs was taken by us on March 22, 1930.

Simcoe County-Set of two eggs (in R.O.M.Z.) was found by H. B. Haugh on March 18, 1923 at Barrie and nest with two young was seen by us at Minesing on May 9, 1925.

Thunder Bay District, Port Arthur-Common resident; fully-fledged young birds were seen on June 28, 1927 and a nest with one frozen egg in March, 1924 by L. S. Dear.

York County, Pottageville-Nest with two large young was examined on May 1, 1927 and a nest with two eggs on March 7, 1925, both by us.

\section{HAWK OWL SURNIA ULULA}

The Hawk Owl is known as a breeder in Thunder Bay and Cochrane Districts $^{31}$ of northern Ontario, where it is a not uncommon summer resident. Its breeding range is unquestionably wider than the above statement indicates, as it has been known to breed as far west as Lake of the Woods (Minnesota) ${ }^{176}$ and to occur in summer as far north as Severn House in northern Kenora District ${ }^{21},{ }^{193}$ and as far south and east as beyond the south-eastern corner of the province, at Lochaber, Quebec ${ }^{23}$.

The American Hawk Owl is ulula caparoch.

Thunder Bay District, Port Arthur-Fledged young were seen with parents on June 28,1927 by L. S. Dear.

\section{BARRED OWL STRIX VARIA}

Strangely enough, the eggs of this owl have not been reported from Ontario. Early published records state that it was a more or less common breeding resident of southern Ontario ${ }^{12},{ }^{128}$ but it is rare at the present time, although it has a wide range and is known to occur irregularly throughout the province north to southern James bay ${ }^{21}$ and west to Lake of the Woods ${ }^{44}$. Macoun makes the following statement ${ }^{170}$ which cannot be accepted, emanating as it does from a collector of known unreliability, "One set of three eggs (in the N.M.C) taken near Chatham, Ontario April 4, 1897. Nest in a hole in a tree about 35 feet from the ground." The date on the eggs is April 30, 1897.

In the same publication ("Catalogue of Canadian Birds", 1903) Macoun quotes Rev. C. J. Young to the effect that a nest had been found in a hole in a tree near Kingston, Ontario but it seems to us that further particulars should be forthcoming before such a record is repeated. L. S. Dear watched two pairs at Port Arthur (Thunder Bay District) during the summer of 1927 but was unable to establish a 
breeding record, although one was watched endeavouring to entice its mate into a hole in a tree. Rev. C. J. Young states that a few years prior to 1903, he saw five young birds that were shot near Brockville, Ontario, in July, and young have recently been observed in Parry Sound District, but these are the only actual breeding records of this bird in the province, of which we are aware. Several nests are recorded from Michigan ${ }^{49}$ mostly in the southern half of the state, and it is said to breed in 75 of the 88 counties $^{207}$ in Ohio!

Our form is the Northern Barred Owl, varia varia.

Muskoka District, Port Sydney-Breeds regularly, according to A. Kay; although there are specimens in R.O.M.Z. taken there by Kay on May 22, 1891 and July 20,1908 , no nests have been located.

Parry Sound District, Katrine-Two adults with one young (down still in evidence) were seen in June, 1933, by R. J. Rutter.

\section{GREAT GRAY OWL SCOTIAPTEX NEBULOSA}

In the breeding season this owl has been observed only at Severn river (on Hudson bay) ${ }^{21},{ }^{25}$ which is its type locality, in the vicinity of Lake Nipissing ${ }^{59}$ and on the Michipicoten river, north Algoma District ${ }^{109}$ (noted on August 19 and 21, 1928).

The only definite breeding record comes from Chisholm township, Nipissing District, where two young were secured on July 31, 1911 (one of these is in N.M.C. and the other is in the collection of J. H. Fleming) but the breeding range of the species may include all of northern Ontario north of Lake Nipissing ${ }^{12}$ (specimens in R.O.M.Z. taken in 1927 at Moose Factory by S. Waller).

Our birds are referred to nebulosa nebulosa.

\section{AMERICAN LONG-EARED OWL ASIO WILSONIANUS}

This owl is a not uncommon summer resident of southern Ontario, breeding from our southern border north to Simcoe County ${ }^{60}$ and Muskoka District and east to Frontenac County. The only recorded nesting records north of Muskoka are those of Morris ${ }^{81}$ who observed a family on July 26, 1906 on the Mattagami river, Cochrane District and Hutchins ${ }^{44}$ (breeding at Severn settlement, Hudson bay, 1782), both of which require confirmation.

It has been collected in summer (June 24,1924 ) at Lake Nipigon ${ }^{19}$ and it is known to breed in Roseau County, Minnesota ${ }^{176}$ adjacent to Lake of the Woods, Ontario. 
Durham County, six miles north of Port Hope-A set of five eggs taken on May 15,1919 , is in possession of J. A. Edwards.

Frontenac County, Portsmouth-Set of four eggs taken on April 28, 1902 by E. Beaupre, is in R.O.M.Z.

Middlesex County - Set of four eggs taken at Poplar Hill by A. A. Wood on April 10, 1921, is in R.O.M.Z. A set of five eggs was found at Coldstream about April 19, 1903 by A. A. Wood, according to C. W. Nash.

Muskoka District, Port Sydney-Breeds, according to A. Kay.

Ontario County, Thorah island, Lake Simcoe- Set of six eggs was found on April 26, 1929 by J. A. Edwards.

Parry Sound District, Katrine-Breeds, according to R. J. Rutter.

Peel County, near Nortonville-Set of four eggs was taken on April 27, 1929 by P. Harrington.

York County, Toronto-Nest with five young was found at Hogg's Hollow on May 24, 1929 by C. N. Brebner. It was shown to J. L. Baillie on the 29th. One of the young is in R.O.M.Z.

\section{SHORT-EARED OWL ASIO FLAMMEUS}

This nearly cosmopolitan species is known to nest in Ontario at a few widely-separated localities, from Norfolk County, on Lake Erie ${ }^{27}$ and Frontenac County, at the east end of Lake Ontario ${ }^{61}$ north to Severn river, on the south shore of Hudson bay ${ }^{25}$ and there is a specimen in R.O.M.Z. taken at Moose Factory on April 29, 1930 by S. Waller.

It is a rare breeding species, excepting perhaps along the shores of Hudson bay ${ }^{9},{ }^{12},{ }^{193}$, where it appears to be common. There is no reason to doubt that it may nest anywhere in Ontario in suitable places.

Ontario birds are likely flammeus flammeus.

Frontenac County, Cataraqui-Set of seven eggs taken on May 24, 1902 by E. Beaupre is in R.O.M.Z. and a nest with well-developed young was examined by Beaupre on May 30, 1906.

Haldimand County, Dunnville-Nest with seven young and two eggs was found between 1885 and 1890 by G. A. MacCallum, according to W. E. Saunders.

\section{ACADIAN OWL CRYPTOGLAUX ACADICA}

This little owl is a not uncommon breeding bird of Ontario from the southern border ${ }^{23},{ }^{27}$ north and west at least to Lake Nipigon ${ }^{19},{ }^{109}$ and probably to James bay, as a specimen has been taken at Moose Factory ${ }^{12}$.

It is sporadically distributed and being of a retiring nature its nesting places are seldom located. Consequently, much has yet to be learned of its actual breeding distribution.

This is the Saw-whet owl of most authors, and our form is acadica acadica.

Muskoka District, Port Sydney-Breeds regularly, two young birds in the so- 
called "Kirtland's" plumage taken by A. Kay on September 12, 1891, are in R.O.M.Z.

Ontario County, Thorah island, Lake Simcoe-Five sets of five and six eggs were found between April 6 and 16,1929 and one set in April, 1930 by J. A. Edwards.

Thunder Bay District, Port Arthur-Set of four eggs was taken on June 23, 1926 by L. S. Dear.

York County, Fisherman's island, Toronto-Brood of five young was collected from nest on May 23, 1928 by J. L. Baillie. 
INDEX TO COUNTIES AND DISTRICTS

\section{Algoma}

Brant.

Bruce...

Curlecon

Cochrase

Dufierin

Durham

Elgin

Essex

Fromlenac

Glengarry

Grenville

Haldımand

Haliburton

Hatron

Iluron

Kenora

Kent

Lambton

Lanark

Lenex and Adelingen

Manntuli

Middllesex

Muskok:

Norfolk

Northumberland

Ontario

Parry Soun

Pert

Pet erborough

Prescutt

Prince Fonduare

Run! kwer

Russell!

Sumcoe

Stormon

Sulliury

Thumer

Victoriat

IIatertero.

Mellanel

IVellingtor

Uentworth

Sork

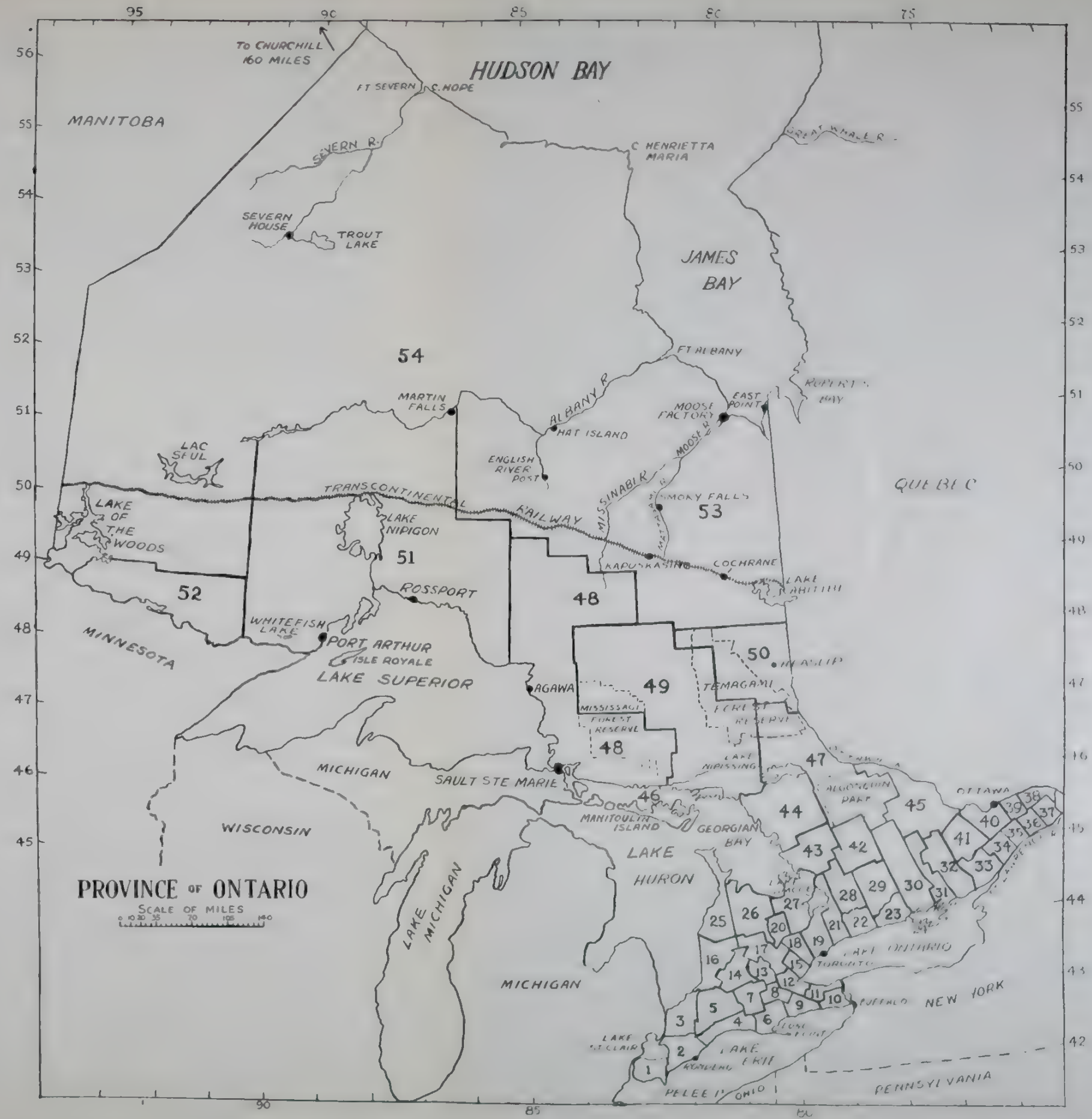





\section{THE DISTRIBUTION OF BREEDING BIRDS IN ONTARIO}

By James L. Baillie, Jr. and Paul Harrington, D.D.S.

(Continued from Vol. XXI, Part I, p. 5o)

\section{PART II}

\section{WHIP-POOR-WILL ANTROSTOMUS VOCIFERUS}

The Whip-poor-will is a fairly common summer resident throughout most of southern Ontario, ranging north to Port Arthur (pair spent summer of 1923 at Fort William according to L. S. Dear) and Temiskaming District ${ }^{62},{ }^{109}$. Its nesting has been recorded at Lake of the Woods County, Minnesota ${ }^{176}$, adjacent to Ontario, but its known breeding range in Ontario extends north only to northern Parry Sound District, near Lake Nipissing.

Our form is vociferus vociferus.

Carleton County, Eastman's Springs-Set of two eggs in N.M.C. was taken on June 15,1931 , by C. E. Johnson.

Haliburton District, Dysart township-Two young were found in nest on June 24,1936 , and two eggs on July 21,1936 , by E. W. Calvert.

Lambton County, Beach O' Pines-Two nests were found in 1936 by K. Reynolds.

Lennox and Addington County, Avenger township-Egg taken on June 6, 1934, by H. B. Jackson is in R.O.M.Z. Set of two eggs in R.O.M.Z. taken by C. K. Clarke on May 27, 1902, is labelled "Addington County".

Muskoka District-J. M. Speirs saw a nest with two young on July 7, 1936, at Torrance and at Honey Harbour, R. Standfield found a nest with two eggs once in late July.

Ontario County, Lot 21, Conc. 4, Pickering township-Nest was found on August 21, 1934, by Silas Tool.

Parry Sound District-Nest with eggs was found in 1904 by J. Edmonds at Ahmic Harbour; downy young were photographed by N. A. Powell on the Magnetawan river.

Simcoe County-At Wasaga beach a set of two eggs was taken on July 4, 1922, by P. Harrington.

Temiskaming District, Uno Park-Nests on the high rocky land, according to Mrs. J. T. Welbourn.

York County, Toronto--Set of two eggs taken on May 27, 1888, at Kew Gardens by J. L. Jackson is in R.O.M.Z.

\section{NIGHTHAWK CHORDEILES MINOR}

The Nighthawk is one of the few species which is common and generally distributed throughout the whole of the province ${ }^{9},{ }^{12}$. It nests in all suitable districts north at least to Lake of the Woods and Thunder Bay and Cochrane ${ }^{193}$ Districts, and probably to Hudson's bay. D. R. Derry considered it common during the summer of 1930 along the Manitoba-Ontario boundary between Lat. $53-54^{\circ} \mathrm{N}$. and it was common 
during the summer of 1927 at Lat. $52^{\circ} \mathrm{N}$. along the same boundary according to R. D. Ussher.

Our form is minor minor.

Algoma District, Kindiogami lake, township 3B or 3C, Mississagi Forest Reserve-Two young were found on a bare rock on July 13, 1923, by R. D. Ussher.

Cochrane District-At Smoky Falls, north of Kapuskasing, a set of two eggs was found on June 24,1933 , by R. V. Whelan. These hatched on July 6 . Nest was found at Moose Factory in 1928, according to S. Waller.

Kenora District, Ontario side of Indian bay, Lake of the Woods-Bred abundantly in 1920, according to letter from W. Rowan.

Kent County, Wheatley-A set of two eggs was taken by W. E. Saunders on June 8, 1909 .

Parry Sound District, Upper Fry lake, Monteith township-Two newly-hatched young in R.O.M.Z., were secured on June 29, 1937, according to H.W. Swaine.

Russell County, Clarence-Set of two eggs taken on June 16, 1896, by F. W. Warwick is in R.O.M.Z.

Simcoe County - Set of two eggs was found on June 8, 1921 by P. Harrington at Collingwood; a set of two eggs in R.O.M.Z. was taken at Barrie by H. B. Haugh on July 15, 1918.

Sudbury District, Bigwood-Set of two eggs was found on June 25, 1914, by F . Starr and set of two eggs, in R.O.M.Z., on July 22, 1937, by C. E. Hope.

Thunder Bay District, Port Arthur-Set of two eggs was taken on June 24, 1924, by L. S. Dear.

York County, Toronto-Two small young were seen on the roof of the Royal Ontario Museum on August 9, 1923, by J. L. Baillie. A set of two eggs taken on June 6,1912 , by T. Glasgow is in the collection of P. Harrington.

\section{CHIMNEY SWIFT CHAETURA PELAGICA}

The swift occurs in Ontario as far north as the Canadian National Railway (transcontinental line) $)^{12}$, sparingly in the north ${ }^{17}$ and quite commonly in the cultivated and settled districts of the southern parts of the province.

It probably breeds throughout its known range but it is known to nest north only to southern Thunder Bay ${ }^{14},{ }^{176}$, Algoma ${ }^{104}$, ${ }^{105}$, central Sudbury and Temiskaming Districts ${ }^{39},{ }^{160}$. Its nesting also in the Lake of the Woods vicinity of Manitoba indicates that its summer range extends westward to the Manitoba-Ontario boundary.

Durham County, Port Hope-Nest with four eggs in R.O.M.Z. was taken on June 2, 1908, by N. H. Meeking.

Elgin County, Aylmer-Set of four eggs in R.O.M.Z. was taken by R. T. Anderson.

Frontenac County-At Simcoe island a set of five eggs was taken on June 27, 1918, by E. Beaupre. It is in R.O.M.Z. It was found nesting at Wensley by W. H. Lunn on July 8, 1934. 
Manitoulin District, Killarney-Nest found in 1930 by H. Spreadborough is in R.O.M.Z.

Muskoka District-Set of five eggs taken at Port Sydney on June 24, 1919, by L. L. Snyder is in R.O.M.Z. At Rebecca lake, W. C. Mansell found a nest on wall of ice-house with four eggs in July, 1933.

Nipissing District-At Green lake, Algonquin Park, a nest with five eggs was found in a shack on July 14, 1910, by S. L. Thompson. W. E. Ricker found young in the ventilators at North Bay Collegiate Institute in June, 1926.

Ontario County-Nest and four small young were found at Pickering on July 15, 1928, by J. Edmonds and J. L. Baillie. P. Harrington found a set of four eggs on June 8, 1914, at Thorah island, Lake Simcoe.

Sudbury District, Biscotasing-New nest, in R.O.M.Z., was found on June 21, 1937, by C. E. Hope.

Thunder Bay District-Fairly common breeder, according to L. S. Dear, at Port Arthur. At Savanne, T. M. Shortt collected a female on July 7, 1937, in R.O.M.Z., which had an egg in oviduct.

Victoria County, Thurstonia Park-Nest with six eggs was found on July 6, 1927 by N. Martin.

\section{RUBY-THROATED HUMMINGBIRD ARCHILOCHUS COLUBRIS}

The Ruby-throated Hummingbird occurs in Ontario from the southern border of the province north to the Albany river ${ }^{191}$ (English river Post in north-western Cochrane District) ${ }^{29},{ }^{31}$ and west to Lake of the Woods. Also it has been seen in the Kapuskasing vicinity (summer, 1925) by R. D. Ussher and at Cochrane (one on August 25, 1931) by T. F. McIlwraith.

Although it probably nests fairly commonly throughout its range, it is known to breed north only to southern Nipissing District ${ }^{39}$; no breeding evidence having been discovered north or west of that district, excepting in the Lake of the Woods vicinity ${ }^{29},{ }^{190}$.

Elgin County, Aylmer-Nest with two eggs taken on May 28, 1898, by R. T. Anderson is in R.O.M.Z.

Frontenac County - Nest and two eggs taken on June 6, 1905, at Sharbot lake by E. Beaupre are in R.O.M.Z. At Kingston on July 9, 1898, E. Beaupre found a nest with two eggs and noted that the same pair had a nest with two young nearby.

Grey County, Mountain lake, near Cape Rich-Nest with two eggs was found on August 7, 1928, by L. H. Beamer.

Hastings County, Tweed-Nest collected about 1909 by E. H. Craigie is in R.O.M.Z. It contained one deserted egg.

Kenora District-A characteristic nesting species in 1920, according to letter from W. Rowan, at Ontario side of Indian bay, Lake of the Woods. A nest, in R.O.M.Z., (contained two eggs) was secured at Wabigoon by T. M. Shortt on June 19, 1937.

Nipissing District, North Bay-Deserted nest has been found by W. E. Ricker.

Norfolk County, Fisher's Glen-Nest with two eggs was seen by A. Buchanan on June 30,1935 , and a nest with young on July 7, 1936, by W. E. Saunders. 
Ontario County, Beaverton-Nest with two eggs was found on July 9, 1911, by J. A. Edwards.

Parry Sound District, Nogranosh lake-Nest found by E. M. S. Dale on August 22, 1929, is in R.O.M.Z.

Simcoe County, Wasaga beach-A set of two eggs (nest in R.O.M.Z.) was found on June 19,1921 , by P. Harrington.

\section{BELTED KINGFISHER MEGACERYLE ALCYON}

This conspicuous bird is common in most localities throughout Ontario $^{8}$, ${ }^{21}$, nesting from the southern border ${ }^{141}$ north at least to Kenora $^{29}$, Thunder Bay and Cochrane Districts, and more than likely throughout the province. It was found to be common during the summer of 1930 by D. R. Derry along the Manitoba-Ontario boundary between Lat. $53-54^{\circ} \mathrm{N}$.

The Kingfisher of eastern Canada is alcyon alcyon.

Algoma District, Amyot-Seven young taken from nest-tunnel on July 2, 1936, by J. L. Baillie, are in R.O.M.Z.

Cochrane District-At Moose Factory it nests at Moose island, according to S. Waller. E. Dixon has eggs collected by A. V. Dukes at Lake Abitibi.

Frontenac County, Simcoe island-Set of seven eggs in R.O.M.Z. was taken on June 8,1898 , by E. Beaupre.

Kenora District, Ontario side of Indian bay, Lake of the Woods-Bred commonly in 1920 , according to letter from W. Rowan.

Middlesex County, London-Set of seven eggs taken on May 12, 1906, is in collection of W. E. Saunders.

Nipissing District-Nest was found at Eau Claire on July 2, 1935, by L. L. Snyder, T. M. Shortt and C. E. Hope. At Green lake, Algonquin Park, S. L. Thompson found a nest with six young (ready to leave) on July 14, 1910.

Simcoe County, Wasaga beach-Set of six eggs was taken on May 28, 1913, by P. Harrington. We saw tunnel with seven eggs there on June 4, 1929.

Thunder Bay District, Rossport-Set of seven eggs in R.O.M.Z. was taken on May 31, 1936, by S. C. Downing.

Victoria County, Bobcaygeon-Nest with five young and two eggs was seen by us on June 10, 1932.

York County, Toronto-Set of six eggs taken on July 2, 1891, by J. L. Jackson is in R.O.M.Z. J. A. Edwards found a set of six eggs in the Don valley on May 20, 1911, and W. P. Young collected a single egg at Toronto island as early as May 10 in 1913.

\section{YELLOW-SHAFTED FLICKER COLAPTES AURATUS}

This is probably the most common of the woodpeckers in Ontario, breeding in suitable places throughout the province ${ }^{9}{ }^{25},{ }^{170},{ }^{193}$, from our southern border to the sea-coast of Hudson's bay. In 1930 it was found by D. R. Derry to be fairly common along the Manitoba-Ontario boundary between Lat. $53-54^{\circ} \mathrm{N}$. 
Our form is said to be auratus luteus.

Algoma District, Amyot-Set of seven eggs, in R.O.M.Z., was taken on June 27, 1936, by J. L. Baillie.

Cochrane District-At Moose Factory it breeds, according to S. Waller, and nests were found by P. A. Taverner and C. E. Johnson at Kapuskasing between June 19 and July 9, 1919.

Durham County, Orono-Nest with three eggs was found on May 5, 1935, by R. A. Smith.

Elgin County, Port Burwell-Set of five eggs was taken on June 18, 1924, by F. Starr.

Kenora District, Ontario side of Indian bay, Lake of the Woods-Bred fairly commonly in 1920 , according to letter from W. Rowan.

Nipissing District, North Bay-Nest with seven or eight naked young was found on June 6,1904 , by S. L. Thompson.

Renfrew County, Pembroke-Nest with young was found on July 11, 1935, by J. L. Baillie.

Temiskaming District, Uno Park-Nests in bird boxes, according to Mrs. J. T. Welbourn.

Thunder Bay District, Port Arthur-Set of six eggs was taken on June 17, 1923, by L. S. Dear.

York County, Toronto-P. Harrington found a set of thirteen eggs on May 18, 1915. At Humber river, C. G. Harbour found a nest with seven young (one week old) on June 3,1911. W. P. Young took a set of eight eggs at the Humber on June 26, 1925.

\section{PILEATED WOODPECKER CEOPHLOEUS PILEATUS}

This handsome resident woodpecker still occurs in some numbers in Ontario, especially in the more heavily-wooded areas, from the southern border ${ }^{22},{ }^{23}$ north to southern James bay ${ }^{12}$.

It breeds in the province north to Kenora ${ }^{29}$, Thunder Bay and Cochrane Districts and appears to be on the increase in many localities. D. R. Derry considered it quite common on July 19, 1930 at the Cobham river, Lat. $53^{\circ} \mathrm{N}$. on the Manitoba-Ontario boundary and George Barnston noted its presence on April 15, (1839?) at Martin's Falls, on the Albany river. ${ }^{178}$

Our form is the Northern Pileated Woodpecker, pileatus abieticola.

Cochrane District, Kapuskasing-Young was collected from nest on July 3, 1919, by P. A. Taverner and C. E. Johnson.

Frontenac County, Mackies lake, Plevna-Set of three eggs taken ${ }^{12}$ on May 15, 1903, by E. Beaupre is in R.O.M.Z.

Haldimand County, Hagersville-Young were seen following parents on Indian reserve in 1878 , by C. W. Nash.

Kenora District, Ontario side of Indian bay, Lake of the Woods-Bred in small numbers in 1920, according to letter from W. Rowan.

Muskoka District-At Port Sydney it breeds, according to A. Kay, and at Bala C. E. Molony saw parent feeding young during the summer of 1934 . 
Parry Sound District, Kearney-Set of seven eggs was found on June 17, 1920, by H. P. Bingham.

Simcoe County, Orillia-Nest with young was found in 1915 by S. Watson.

Sudbury District, 40 miles south of Chapleau-Nest with young was found on June 9, 1937, by C. E. Hope and J. L. Baillie.

Thunder Bay District, Port Arthur-Set of four eggs was found on May 13, 1930 , by L. S. Dear; nest with young was seen by us on June 7, 1935 .

Victoria County, Woodville-Set of four eggs was found on May 16, 1932, by P. Harrington.

\section{RED-BELLIED WOODPECKER CENTURUS CAROLINUS}

This woodpecker was formerly a not uncommon resident of southwestern Ontario, breeding north to Wellington County and east to Halton County ${ }^{63}$. An immature was shot also on July 27, 1894, as far north as Oak lake, near Havelock, Peterboro County, by J. H. Samuel ${ }^{12}$ and there is a record ${ }^{95}$ for Sault Ste. Narie, but these may be considered extralimital. At present, it is known to nest only in Middlesex County ${ }^{22}$ (and very rarely there) but J. H. Smith observed a male on June 25, 1933, in Rondeau Park, Kent County.

Elgin County, Aylmer-Set of two eggs taken by R. T. Anderson is in R.O.M.Z.

\section{RED-HEADED WOODPECKER MELANERPES ERYTHROCEPHALUS}

The Red-headed Woodpecker is a summer resident of Ontario, breeding not uncommonly in the south-western sections, sparingly in the central and eastern districts, and rarely north to Lake Nipissing ${ }^{6 t}$ and southern Thunder Bay District ${ }^{95}$. Thompson ${ }^{44}$ quotes an old record for Fort Albany, James bay, (probably erroneous) and L. Paterson saw one at Kenora (Lake of the Woods) on September 7, 1930. It probably nests throughout its range, and does so definitely north at least to Port Arthur and Lake Nipissing.

Durham County, Enniskillen-Set of six eggs taken ${ }^{170}$ in 1892 by O. Byers is in N.M.C.

Frontenac County-Set of seven eggs taken at Wolfe island on May 29, 1898, by M. Grimshaw, set of one egg taken on May 14, 1898, at Wolfe island by C. K. Clarke and set of three eggs taken at Kingston on July 10, 1897, by C. M. Clarke are in R.O.M.Z.

Huron County, near Goderich-Nest has been found by C. H. D. Clarke.

Kent County, Rondeau-Adult was seen by us at nest on June 7, 1933.

Muskoka District, Port Sydney-Breeds, according to A. Kay.

Northumberland County, Cobourg-Eggs were taken by N. A. Powell between 1861-69.

Simcoe County, Wasaga beach-Adult with young was seen on July 1, 1923, by P. Harrington. 
Thunder Bay District, Port Arthur-Set of four eggs was taken on June 26, 1927 , by L. S. Dear.

Welland County, Sherkston-Set of five eggs taken on May 31, 1895, by E. Reinecke is in N.M.C.

York County, Toronto-J. A. Edwards found a set of four eggs at Wychwood Park on June 3,1911 , and at High Park, R. A. Smith examined a nest with three young on June 14, 1936.

\section{YELLOW-BELLIED SAPSUCKER SPHYRAPICUS VARIUS}

The sapsucker is a common summer resident of most sections of Ontario north to Lat. $55^{\circ} \mathrm{N}$. on the Manitoba boundary ${ }^{29},{ }^{176}$ and James bay $^{12}$. D. R. Derry noted it during the summer of 1930 along the Manitoba-Ontario boundary between Lat. $53^{\circ}$ and $54^{\circ} \mathrm{N}$. and at Moor lake, Manitoba, Lat. $52^{\circ} \mathrm{N}$. (on Ontario boundary) R. D. Ussher found a nest on July $8,1927$.

It nests commonly ${ }^{31}$ in the central parts of the province north at least to the Transcontinental railway but in the extreme south-western peninsula and bordering Lake Ontario it breeds only rarely.

Our form is varius varius.

Algoma District, Bachawana bay-Young were seen in nest on July 12,1935 , by C. H. D. Clarke:

Cochrane District, Kapuskasing-Several nests were found by P. A. Taverner and C. E. Johnson between June 19 and July 9, 1919.

Kenora District-Bred abundantly in 1920 on Ontario side of Indian bay, Lake of the Woods, according to letter from W. Rowan. At Ponask lake (Lat. $54-55^{\circ} \mathrm{N}$. close to Manitoba boundary) J. Satterly found a nest with young on July $3,1936$.

Leeds County, Junetown-Set of four eggs taken by E. Beaupre on May 23, 1900 , is in R.O.M.Z.

Nipissing District, Wilson lake, Temagami Forest Reserve-Young were seen on August 5, 1934, by O. E. Devitt.

Parry Sound District, Pickerel lake, near Burk's Falls-Nest with young was seen on July 12, 1936, by J. L. Baillie.

Renfrew County, Lake Doré-Nest with young was found on June 25,1935 , by C. E. Hope.

Simcoe County-Set of four eggs was found at Minesing by us on June 7, 1928. H. P. Bingham took a set of six eggs at Barrie on June 2, 1918. Parent was seen with one young at DeGrassi point on July 10, 1933, by E. R. Hunter.

Sudbury District, Bigwood-Nest with young was found on June 27, 1914, by F. Starr.

Thunder Bay District, Port Arthur-Set of five eggs was taken on June 27, 1928, by L. S. Dear.

\section{HAIRY WOODPECKER DRYOBATES VILLOSUS}

The Hairy Woodpecker is a fairly common breeding resident of Ontario, north at least to the Transcontinental railway ${ }^{12},{ }^{29}$, west to 
Lake of the Woods and possibly northward along the Manitoba boundary, as it was noted there (between Lat. $53^{\circ}$ and $54^{\circ} \mathrm{N}$.) during the summer of 1930 by I. R. Derry. To the north of the Canadian National Railway (transcontinental line) it has been noted at Moose Factory ${ }^{12}$ and at Hat island, on the Albany river ${ }^{94}$.

The Hairy Woodpecker of most of Ontario is villosus villosus but in northern Ontario the breeding form of this species has been recorded ${ }^{19},{ }^{31}$ as villosus septentrionalis.

Algoma District, Township 4A, Mississagi Forest Reserve-Parents were seen feeding young in the nest on June 6,1923 , by R. D. Ussher.

Frontenac County, Loughboro township-Set of four eggs in R.O.M.Z. was taken on May 4, 1897, by E. Beaupre.

Haliburton District, Haliburton-A set of four eggs in R.O.M.Z. was taken on June 5, 1913.

Kenora District, Ontario side of Indian bay, Lake of the Woods-Nested fairly plentifully in 1920, according to letter from W. Rowan.

Middlesex County, Coldstream-A. A. Wood found a nest with three young on May 26, 1918.

Muskoka District, Port Sydney-Set of three eggs taken by A. Kay on May 12, 1893, is in R.O.M.Z.

Simcoe County-Set of five eggs was taken on May 3, 1922, by P. Harrington at Wasaga beach and a nest with young was seen by us at Minesing on May 9 , 1925.

Thunder Bay District, Port Arthur-Pair was seen with fledged young on June 5,1927 , by L. S. Dear.

Victoria County, Bobcaygeon-Nest with young was seen by us on June 10, 1932.

York County-P. Harrington saw a family of adults and young on May 27, 1922 , and a nest with young was seen by him on May 19, 1929, both at Toronto; egg in R.O.M.Z. was taken at Weston on May 24, 1905, by L. B. Brown.

\section{DOWNY WOODPECKER DRYOBATES PUBESCENS}

The Downy Woodpecker is a resident bird of Ontario north to southern James bay ${ }^{12}$ and west to Lake of the Woods ${ }^{29}$, breeding commonly throughout its range.

The eastern Canadian form is pubescens medianus.

Algoma District, Amyot-Set of three eggs in R.O.M.Z. was taken on June 25, 1936, by C. E. Hope.

Cochrane District-At Lake Abitibi A. V. Dukes has collected eggs, according to E. Dixon, and at Kapuskasing young were seen with parents on July 5, 1919, by P. A. Taverner and C. E. Johnson.

Frontenac County, Rockwood-Set of four eggs found on May 21, 1898, by H. Clarke is in R.O.M.Z.

Kenora District, Ontario side of Indian bay, Lake of the Woods-Nested abundantly in 1920, according to letter from W. Rowan.

Kent County, Rondeau-Nest with young was seen by us on June 12, 1933. 
Middlesex County, London-Set of four eggs taken on May 18, 1906, is in collection of W. E. Saunders.

Parry Sound District, Frank's bay, Lake Nipissing-Nest was found on June 25, 1929, by W. E. Ricker.

Simcoe County, Barrie-Set of six eggs was taken by H. P. Bingham on May $23,1915$.

Sudbury District, Bigwood-Nest with young was found on June 25, 1914, by F. Starr.

Thunder Bay District, Port Arthur-Set of five eggs was taken on June 12, 1927, by L. S. Dear.

\section{ARCTIC THREE-TOED WOODPECKER PICOIDES ARCTICUS}

This is a fairly common resident bird from Muskoka District ${ }^{41}$ and Algonquin Park ${ }^{171}$ north to James bay ${ }^{12}$ and west to the Manitoba boundary, where it was noted by D. R. Derry during the summer of 1930 (between Lat. $53^{\circ}$ and $54^{\circ} \mathrm{N}$.). It nests north at least to the Transcontinental railway ${ }^{29},{ }^{31}$, according to our records.

Algoma District, Township 4c (Round lake and Minnesenagua lake district), Mississagi Forest Reserve-Young were found in nest on June 25, 1923, by R. D. Ussher.

Cochrane District, Kapuskasing-Nest with young was found in late June, 1919, by P. A. Taverner and C. E. Johnson.

Kenora District, Ontario side of Indian bay, Lake of the Woods-Found breeding at High lake in 1920, according to W. Rowan.

Muskoka District, Port Sydney-Breeds, according to A. Kay.

Nipissing District-Young male in R.O.M.Z. was taken by D. A. MacLulich on July 25, 1933, at Biggar lake, Algonquin Park. A nest, in R.O.M.Z., collected by A. F. Coventry and W. Tovell, on July 21, 1937, at Outlet bay, Temagami, was occupied when found on July 5.

Parry Sound District, Sand lake-Set of three eggs taken on May 30, 1894, by J. H. Fleming, is in R.O.M.Z.

Thunder Bay District, Stanley-Set of four eggs taken on May 18, 1930, by L. S. Dear, is in R.O.M.Z.

\section{AMERICAN THREE-TOED WOODPECKER PICOIDES TRIDACTYLUS}

This rare woodpecker occurs in Ontario in suminer north from Lat. $48^{\circ} \mathrm{N}$. to Hudson's bay ${ }^{9}$.

The only places where it is known to have nested are Lake Abitibi ${ }^{31}$ and Severn river, on Hudson's bay ${ }^{25}$, but at Kapuskasing C. E. Johnson collected a female on July 1 and a male on July 3, 1919 (now in N.M.C.). R. T. Morris noted the species on June 30, 1906, at Winnebago ${ }^{81}$, Sudbury District, J. E. Cabot ${ }^{82}$ noted it between Pic and Fort William 'Thunder Bay District) in July, 1848, and Murray ${ }^{193}$ records it from Severn House, 
on Severn river. Also, R. D. Ussher saw one during the summer of 1927 at Lat. $52^{\circ} \mathrm{N}$. on the Manitoba-Ontario boundary.

The form occurring in Ontario is tridactylus bacatus.

\section{KINGBIRD TYRANNUS TYRANNUS}

The Kingbird is a summer resident of Ontario, common in the southern parts and occurring north to James bay, breeding from the southern border north to Lake of the Woods ${ }^{29}$, ${ }^{176}$, southern Thunder Bay and Temiskaming Districts.

Its occurrence on August 28, 1904, at Albany river, on James bay ${ }^{12}$ and at Moose Factory (one in R.O.M.Z. taken on June 2, 1928 by $\mathrm{S}$. Waller) suggests that its breeding range may extend north to James bay.

It was regarded as a new arrival at Kapuskasing, on the Canadian National Railway (transcontinental line) in 1919, according to P. A. Taverner.

Algoma District, Bachawana bay-C. H. D. Clarke saw nest with young on July 13, 1935.

Halton County, Glen Williams-Set of three eggs in R.O.M.Z. was taken on June 10, 1905, by L. B. Brown.

Huron County, West Wawanosh township-Set of three eggs, collected on June 20,1934 , is in the possession of S. C. Downing.

Kenora District, Ontario side of Indian bay, Lake of the Woods-Bred commonly in 1920, according to letter from W. Rowan.

Lincoln County, Rosedene-Nest with four eggs was found on June 6, 1933, by G. J. Clout.

Parry Sound District-At Pickerel lake, east of Burk's Falls, a nest with three eggs was found on July 16,1935 , by J. L. Baillie. At Frank's bay, Lake Nipissing, C. H. D. Clarke found a nest with two eggs on June 27, 1933.

Peterborough County, Jack's creek, Stony lake - Nest with two young and one egg was found on July 6, 1921, by J. L. Baillie.

Temiskaming District, Uno Park-Nests, according to Mrs. J. T. Welbourn.

Thunder Bay District, Port Arthur-Set of four eggs was found on June 22, 1926, by L. S. Dear.

Victoria County, Kirkfield-J. A. Edwards has a set of three eggs taken on June $7,1913$.

\section{CRESTED FLYCATCHER MYIARCHUS CRINITUS}

The Crested Flycatcher is a fairly common summer inhabitant of Ontario north to southern Algoma District ${ }^{17}$ and Lake Nipissing ${ }^{64}$.

Although we are aware of no breeding records north of Muskoka District and Renfrew County ${ }^{165}$, it most likely nests throughout its stated range.

Our birds are considered to be crinitus boreus. 
Carleton County, Mer Bleue-Nest and six eggs in N.M.C were taken on June 11,1908 , by C. H. Young.

Durham County, Bowmanville-Nest with four young and two eggs was found on June 22,1927 , by A. E. Allin.

Essex County, Point Pelee-Set of five eggs in N.M.C. was taken on June 16, 1913 , by P. A. Taverner and C. H. Young.

Frontenac County-Set of four eggs was found on May 30, 1898, by E. Beaupre at Portsmouth. At Simcoe island on June 18, 1898, a nest with five small young was found by C. J. Young and E. Beaupre.

Grey County, Meaford-A nest with five eggs was seen on June 28, 1936, by L. H. Beamer.

Muskoka District, Lake Joseph-Nest with young was found on July 3, 1922, by R. D. Ussher.

Simcoe County-At Wasaga beach, set of four eggs was taken on June 18, 1922, and set of four eggs on July 8,1922 , by P. Harrington. At DeGrassi point, E. R. Hunter saw parents feeding two or three young on July 28, 1933.

Victoria County, Bobcaygeon-Set of two eggs in R.O.M.Z. was found on June 6,1931 , by P. Harrington.

Wentworth County, Hamilton-Nest with four young was found in 1931 by P. Henderson.

York County-Set of six eggs was found on June 10, 1911 by J. A. Edwards at Wychwood park, Toronto. At Strange, a nest with four young, found on July 7,1935 by R. D. Ussher, was vacated on July 9 .

\section{EASTERN PHOEBE SAYORNIS PHOEBE}

The Phoebe is a common summer resident of most of Ontario, breeding north to the transcontinental line of the Canadian National Railway and west to the southern Manitoba-Ontario boundary ${ }^{29},{ }^{176}$.

Elgin County, Port Burwell-Set of five eggs was found on June 11, 1924, by F. Starr.

Hastings County, near Bannockburn-Set of four eggs (originally five) in R.O.M.Z. was taken on May 30, 1921, by W. H. Lunn.

Kenora District-Bred abundantly in 1920 at Ontario side of Indian bay, Lake of the Woods, according to letter from W. Rowan. B. W. Cartwright found a nest with five eggs on May 24, 1932, at Clearwater bay, eight miles southwest of Keewatin.

Lincoln County-Nest with four eggs was found at Rockway on April 30, 1933, by G. J. Clout, who also found a nest with four young on May 26, 1935, at Niagara-on-the-lake, and a nest with four young at St. Catharines on July 4, 1936.

Ontario County, Beaverton-J. A. Edwards saw nest with four eggs on July 15, 1909.

Peterborough County, Lakefield-Nest with five eggs was found on July 6, 1923, by J. L. Baillie.

Renfrew County, Petawawa-Set of three eggs was found on June 1, 1916, by P. Harrington.

Sudbury District, Bigwood-Set of four eggs was taken on June 27, 1914, by F. Starr, and brood of four nestlings, in R.O.M.Z., was obtained on July 17, 1937, by J. L. Baillie. 
Thunder Bay District-Set of five eggs was found on May 21, 1911, at Port Arthur by L. S. Dear and five eggs were seen by us in nest at Whitefish lake on June 3, 1935. R. D. Ussher saw bird feeding young on July 31, 1924, at a lake north of Mack.

York County, Toronto-P. Harrington took a set of four eggs plus egg of Cowbird on May 7, 1915, and at Don river J. M. Speirs found a nest with young on June $15,1935$.

\section{YELLOW-BELLIED FLYCATCHER EMPIDONAX FLAVIVENTRIS}

This small flycatcher is a not uncommon summer resident of Ontario from the northern part of Wellington County ${ }^{65}$ to the transcontinental line of the Canadian National Railway ${ }^{19},{ }^{31}$ and west to Lake of the Woods (noted in the summer of 1920 on the Ontario side of Indian bay, according to letter from W. Rowan).

It has been recorded as breeding in Wellington County, in Bruce County $^{12}$ and in Parry Sound and Muskoka Districts ${ }^{39}$ but the only recent nesting occurrences of which we are aware are from Port Arthur. Barrows ${ }^{49}$ states that it breeds in Marquette County, Michigan (on the south shore of Lake Superior).

Its south-eastern breeding limit in the province is probably Carleton County ${ }^{23}$ as a female (marked incubating) was taken at Mer Bleue on June 13, 1891, by F. A. Saunders, according to the journals of W. E. Saunders. That it may nest as far south as Lake Ontario is suggested by the record from Amherst island (given below) and by the fact that it is known to breed ${ }^{211}$ in St. Lawrence County, New York, adjacent to Ontario.

Lennox and Addington County, Amherst island-"On July 1, 1921, near the marsh I found a nest of the Yellow-bellied Flycatcher. The nest was made of dry grass and rootlets and was placed on the side of a hummock of grass. The four young ones were covered with jet black down". (Diary of E. Beaupre in R.O.M.Z.)

Thunder Bay District, Port Arthur-Nest (in R.O.M.Z.) with four eggs was taken on June 24,1934 , by L. S. Dear, who also collected a set of four eggs in late June, 1936.

\section{ACADIAN FLYCATCHER EMPIDONAX VIRESCENS}

This flycatcher has been found on a few occasions in Essex, Kent, Middlesex and Haldimand Counties, all in the neighbourhood of Lake Erie.

A nest with three eggs was reported ${ }^{66}$ at Dunnville (Haldimand County) on June 24, 1884 by Dr. G. A. MacCallum but at the present time it is known to nest only at Rondeau Park, where it breeds not uncommonly. On the south shore of Lake Erie it has been found 
breeding at least at Presque isle, Erie County, Pennsylvania ${ }^{208}$ and also in Niagara County ${ }^{211}$, New York.

Kent County-At Rondeau Park a nest with three eggs (nest in R.O.M.Z.) was found on June 14, 1931, by T. D. Patterson and another nest with eggs by F. H. Emery; on June 12, 1933, we found four nests containing two, two, three and three eggs respectively. At Renwick W. E. Saunders collected a female on June 8,1909 , which contained an egg ${ }^{192}$ almost ready for extrusion.

\section{TRAILL'S FLYCATCHER EMPIDONAX TRAILLI}

The Traill's Flycatcher is a fairly common and generally distributed summer resident ${ }^{41}$ of Ontario north to southern James bay ${ }^{12}$, breeding at least from the southern limit of the province north to Thunder Bay District and Lake Abitibi ${ }^{31}$.

This is the Alder Flycatcher of most authors, and the form occurring in Ontario is trailli trailli.

Algoma District, Bachawana bay-Adult was seen feeding young on July 18, 1935, by C. H. D. Clarke.

Hastings County, Bird Creek-Nest with two eggs was collected on June 22, 1935, by T. M. Shortt. They are in R.O.M.Z.

Nipissing District-At Biggar lake, Algonquin Park, young were seen on July 18, 1933, by C. H. D. Clarke. At North Bay W. E. Ricker found a nest with four eggs on June 21, 1925.

Peel County, Clarkson-Set of two eggs, plus egg of Cowbird, was taken on June 30,1920 , by F. Starr.

Perth County, Listowel-A set of three eggs, taken on July 21, 1902, by A. A. Perrin is in the collection of P. Harrington.

Simcoe County, Barrie-Nest and set of four eggs (one later destroyed) taken on July 1, 1918, by H. B. Haugh are in R.O.M.Z.

Sudbury District, Biscotasing-Nest with four eggs, in R.O.M.Z., was secured by C. E. Hope on June 25, 1937.

Thunder Bay District, Port Arthur-Set of four eggs was taken on July 1, 1924, and set of three eggs on July 1, 1923, by L. S. Dear.

Victoria County, Bobcaygeon-Nest and three eggs were taken on June 14, 1931, by P. Harrington.

York County-Set of four eggs in R.O.M.Z. was taken at Toronto on June 13, 1890 , by J. L. Jackson. On July 13, 1934, C. E. Hope found a nest with four young at Mount Dennis, and a nest with three young at the same place on July 26, 1936 .

\section{LEAST FLYCATCHER EMPIDONAX MINIMUS}

The Least Flycatcher is a fairly common breeding summer resident of the province north to southern Kenora District ${ }^{29}$ and southern James bay $^{12}$.

Cochrane District-Nest with four eggs (in R.O.M.Z.) was found on June 18, 1930, by S. Waller at Moose Factory. A. V. Dukes collected eggs at Lake Abitibi, according to E. Dixon. 
Frontenac County, Sharbot lake-Set of four eggs in R.O.M.Z. was found on June 9,1902 , by $\mathrm{E}$. Beaupre.

Kenora District, Kenora-On June 12, 1930, L. Paterson found a nest with four eggs.

Lennox and Addington County, Avenger township-Nest with four eggs in R.O.M.Z. was taken on June 5, 1934, by H. B. Jackson.

Muskoka District-At Robinsdale a nest with four eggs was photographed on June 9, 1923, by A. W. Needler. At Rebecca lake W. C. Mansell found an occupied nest in July, 1934.

Parry Sound District-At Pickerel lake, near Burk's Falls, young just out of the nest was collected on July 16, 1936, by J. L. Baillie; it is in R.O.M.Z. At Frank's bay, Lake Nipissing, one was seen building nest on June 14, 1933, by C. H. D. Clarke.

Simcoe County, Barrie-Set of four eggs was taken on June 3, 1915, by H. P. Bingham, and J. M. Speirs saw young being fed by parents on June 30, 1937.

Thunder Bay District, Port Arthur-Set of four eggs was found on June 25, 1924, by L. S. Dear.

Victoria County, Bobcaygeon-Set of two eggs was taken on July 1, 1933, by F. Starr.

York County, Toronto-Set of three eggs taken at Kew gardens on June 23, 1889 , by J. L. Jackson is in R.O.M.Z.

\section{EASTERN WOOD PEWEE MYIOCHANES VIRENS}

The Wood Pewee is a fairly common breeding summer resident of Ontario north to southern Thunder Bay ${ }^{14}$ and southern Sudbury Districts $^{39},{ }^{64}$.

Its breeding range undoubtedly extends somewhat farther north, as it has been recorded as a common summer resident at Spanish river, southern Algoma District ${ }^{104}$ and as a summer resident at Lake of the Woods (Manitoba) ${ }^{29}$, at Gargantua ${ }^{17}$ (near Agawa) and in Temagami ${ }^{62}$.

Essex County, Point Pelee-Nest in R.O.M.Z. was found on June 20, 1920, by L. L. Snyder.

Frontenac County-Set of two eggs in R.O.M.Z. was taken at Newcourt on June 8,1898 , by C. K. Clarke and set of four eggs in R.O.M.Z. was taken at Portsmouth on July 6,1898 , by E. Beaupre.

Halton County, Oakville-Set of three eggs taken by J. L. Jackson on August 8,1890 , is in R.O.M.Z.

Huron County, West Wawanosh township-Set of two eggs was taken on July 31, 1935, according to R. Smyth.

Middlesex County, 7 miles north-east of London-Set of three eggs was taken on June 6,1908 , by W. E. Saunders.

Nipissing District, North Bay-S. L. Thompson saw an adult at nest on June 10,1904 .

Simcoe County-Set of two eggs was taken on July 27, 1914, by P. Harrington at Wasaga beach. At Penetang a nest was taken on June 14, 1935, by C. E. Hope. It is in R.O.M.Z.

Sudbury District, Bigwood-Female in R.O.M.Z., taken on July 14, 1937, by J. L. Baillie, contained an egg (with shell). 
Thunder Bay District, Port Arthur-Nest with four small young was located on

July 15,1928 , by L. S. Dear.

York County-A nest with one egg was found on August 2, 1927, by R. V. Lindsay, at Toronto. A nest with two eggs in R.O.M.Z. was taken at Thornhill on July 14, 1902, by J. Parke.

\section{OLIVE-SIDED FLYCATCHER NUTTALLORNIS MESOLEUCUS}

This flycatcher is a not uncommon summer resident of Ontario in suitable places north from about Lat. $44^{\circ} \mathrm{N}$. to James bay ${ }^{12}$ and west tug $^{10}$ to Thunder Bay District ${ }^{176}$. Its occurrence in the Lake of the Woods section of Manitoba $^{29}$ indicates that its range probably extends westward to the western extremity of Ontario.

It probably breeds throughout its summer range ${ }^{31},{ }^{67}$.

Muskoka District, Port Sydney-Breeds, according to A. Kay.

Parry Sound District, Restoule and Memesogamesing lakes, Patterson and Hardy townships-Three families were seen in August, 1903, by E. H. Eaton, according to his letter to J. H. Fleming dated February 13, 1905.

Sudbury District, Bigwood-Young, in R.O.M.Z., was secured by C. E. Hope, on July 27, 1937.

Thunder Bay District-At Port Arthur, a set of three eggs was taken by L. S. Dear with nest on June 24, 1934. The nest is in R.O.M.Z. Another nest with one egg was found by Colonel Dear on July 2, 1928, but it was destroyed on the 6 th. At Peninsula a set of three eggs was collected by C. E. Hope on June 21, 1936; this set is in the collection of P. Harrington.

\section{HORNED LARK OTOCORIS ALPESTRIS}

The Horned Lark breeds fairly commonly in the cultivated sections of Ontario north to southern Kenora ${ }^{12}$ District, southern Sudbury District $^{39}$ and Ottawa ${ }^{23}$ (and possibly considerably farther ${ }^{132}$ ) and again commonly along the western coast of James bay, north to Cape Henrietta Maria, and probably north-westward to the Manitoba boundary 9 .

The race of this species breeding in extreme northern Ontario is probably alpestris alpestris ${ }^{9}$ but the form inhabiting the greater part of the province is the Prairie Horned Lark, alpestris praticola.

Carleton County, Ottawa-Young taken by F. A. Saunders on June 8, 1891, is in the collection of W. E. Saunders.

Frontenac County-Set of four eggs in R.O.M.Z. was taken on April 3, 1898, by C. K. Clarke at New Court. At Kingston, E. Beaupre found a nest with three young on April 9, 1898.

Hastings County, Stirling-Nest with three eggs was found by E. W. Calvert on April 4, 1927.

Lambton County, Sarnia-W. A. Dent found nest with three eggs on March 13, 1911, according to W. E. Saunders. 
Lincoln County-At St. Catharines, G. J. Clout found a nest with three eggs on May 25, 1936. At Beamsville young were seen out of the nest on June 18, 1918, by H. M. Laing, according to the "Globe", June 19, 1920.

Muskoka District, Port Sydney - Nest with two eggs taken on May 4, 1899, by A. Kay is in R.O.M.Z.

Norfolk County, Simcoe-A nest with three eggs was found on March 25 by M. Landon, who has a photograph of it.

Parry Sound District, Katrine - Nest was found in 1927 by R. J. Rutter.

Sudbury District, Bigwood-Young, still with parents, was collected on July 20, 1937, by J. L. Baillie; it is in R.O.M.Z.

York County, Toronto-At Toronto island, J. H. Samuel saw a nest with three eggs on March 22, 1898, and saw young awing on April 19,1897. A nest with four eggs was found at Ashbridge's bay on June 24, 1935, by H. H. Southam and a set of three eggs in R.O.M.Z. was found at Centre island on July 3,1904 , by L. B. Brown.

\section{TREE SWALLOW IRIDOPROCNE BICOLOR}

This species is probably the commonest and most widely-distributed of the swallows in Ontario, occurring in summer from the southern border north at least to James bay ${ }^{12}$ and probably north throughout the province ${ }^{9}$.

It is known to nest commonly north to southern James bay ${ }^{19},{ }^{31}$ and west to the southern Manitoba-Ontario boundary ${ }^{29}$ and probably farther northward, as it was found fairly commonly during the summer of 1930 by $\mathrm{D}$. R. Derry along the boundary between Lat. $53-54^{\circ} \mathrm{N}$.

Algoma District, Amyot-Nest with six young, in R.O.M.Z., was collected by J. L. Baillie on June 25, 1936.

Cochrane District-Nests, according to S. Waller, on Moose island at Moose Factory, and at Kapuskasing a pair nested (June 19 to July 9) in 1919, according to P. A. Taverner. Young, scarcely able to fly, taken on July 19, 1936, by R. V. Whelan at Smoky Falls, is in R.O.M.Z.

Frontenac County, Collins' lake-Nest with six eggs was found on June 2, 1922, by C. J. Young.

Huron County, West Wawanosh township-Set of five eggs was secured on June 6,1935 , according to R. Smyth.

Kenora District, Kenora-L. Paterson found a set of five eggs on June 7, 1931, in a bird box, according to B. W. Cartwright.

Kent County, Rondeau-Nest in hanging cocoanut-shell "bird box" was seen by us on June 6, 1933, in the garden of Dr. C. C. Bell.

Ontario County, Frenchman's bay-Nest with five eggs was found by C. E. Hope on May 26, 1929.

Simcoe County-At Collingwood a nest with seven eggs was found on June 11, 1920 , by P. Harrington and at Little lake, H. P. Bingham found a set of four eggs (in R.O.M.Z.) on May 21, 1922. At DeGrassi point young were being fed in nest on June 27, 1936, according to E. R. Hunter.

Temiskaming District, Uno Park-Nests in bird boxes, according to Mrs. J. T. Welbourn. 
Thunder Bay District, Port Arthur--Set of three eggs was collected on July 3, 1927 , by L. S. Dear.

\section{BANK SWALLOW RIPARIA RIPARIA}

This is a common and widely, though sporadically, distributed breeding bird of Ontario, nesting in colonies from the southern border ${ }^{27}$ north to Hudson bay ${ }^{8},{ }^{12},{ }^{44},{ }^{68}$ in suitable places and west to Lake of the Woods.

The Ontario form of the species is riparia riparia.

Cochrane District, Moose Factory-Nest with four eggs in R.O.M.Z. was taken on June 20,1930 , by S. Waller.

Frontenac County, Kingston-Set of five eggs was taken by E. Beaupre on June $4,1897$.

Kenora District, Kenora-L. Paterson found a nest on June 15, 1930.

Lincoln County, Port Dalhousie-Nest with four young was found on July 1, 1935, by R. A. Smith.

Northumberland County-Colony of five hundred pairs was found at Brighton on July 2, 1935, by J. L. Baillie. W. H. Lunn took a set of two eggs (in R.O.M.Z.) near Trenton on May 21, 1921.

Ontario County, Thorah island, Lake Simcoe-Set of six eggs was found on June 10, 1914, by P. Harrington.

Renfrew County, Arnprior-Colony of two hundred pairs was found on July 11, 1935 , by J. L. Baillie.

Sudbury District, Larchwood-Colony of 25 or more pairs was seen on July 7 , 1936, by S. C. Downing, C. E. Hope and J. L. Baillie.

Thunder Bay District-Set of four eggs was collected at Port Arthur on June 27, 1927, by L. S. Dear. At Kakabeka Falls, J. L. Baillie saw one enter tunnel in sandbank on June 29, 1929.

York County, Toronto-Set of five eggs was found on May 30, 1914, by P. Harrington and set of three eggs (in R.O.M.Z.) was taken by J. L. Jackson on July $17,1892$.

\section{AMERICAN ROUGH-WINGED SWALLOW STELGIDOPTERYX RUFICOLLIS}

The breeding range of the Rough-winged Swallow in Ontario extends from the southern border ${ }^{128}$ north to Ottawa ${ }^{23}$ and south Georgian bay (and probably to Manitoulin District, as four were seen at South Bay mouth on August 5, 1934 by J. M. Speirs). It breeds also at Lake of the Woods ${ }^{29}$ (Manitoba) and probably on the Ontario side, in which region there appears to be a marked southern tendency in the avifauna.

It is not a particularly numerous species but in certain places it is found in some numbers.

The Ontario form is ruficollis serripennis.

Frontenac County, Kingston-Three pairs were found nesting on June 11, 1924, by E. Beaupre. 
Grey County, Meaford-One was seen at nest on May 26, 1935, by F. H. Emery.

Huron County, Goderich-Nest (in R.O.M.Z.) contained three eggs on June 12, 1936, according to C. H. D. Clarke.

Lincoln County - Nest with eggs was found in 1932 in crevice of old stone wall by G. J. Clout at St. Catharines. At Niagara-on-the-lake, W. P. Young took a set of five eggs on June 23, 1926.

Middlesex County, London-W. E. Saunders has a set of seven eggs taken by him on June $15,1900$.

Perth County, St. Mary's-Nest with one egg in R.O.M.Z. was taken on June 1, 1935, by C. E. Hope.

Simcoe County - Set of four eggs was taken at Wasaga beach on July 1, 1928 by P. Harrington, and H. P. Bingham took a set of four eggs at Barrie on June $13,1918$.

Victoria County, Kirkfield-A set of five eggs is in collection of E. Dixon.

Wellington County, Rockwood-Several pairs were found nesting on July 2, 1927, by R. V. Lindsay.

York County-A nest with four young was taken by C. E. Hope at Pottageville on July 12, 1931, and at Grenadier pond, Toronto, S. C. Downing and R. Smyth found a nest with five eggs on June 9, 1935. At Don river, R. J. Rutter found a nest with two eggs on May 26, 1934.

\section{BARN SWALLOW HIRUNDO ERYTHROGASTER}

In Ontario this is a common breeding swallow, nesting in colonies near habitations from Lake Erie ${ }^{109}$ north at least to northern Lake of the Woods $^{176}$ (and Isle Royale, Michigan ${ }^{49}$ ), Chapleau (Sudbury District) and Temiskaming District (approx. Lat. $48^{\circ} \mathrm{N}$.). It may range north to the transcontinental line of the Canadian National Railway, as five were seen at Mattice (southern Cochrane District) on August 26, 1931, by T. F. McIlwraith and one was killed at Moose Factory in 1924 by Clarence Hester (according to S. Waller).

Essex County, Pelee island-Nest with three eggs was found by us on June 4, 1933.

Huron County, West Wawanosh township-Set of four eggs was taken on July 26, 1934, according to R. Smyth.

Kenora District, Ingolf-New nest was found by L. L. Snyder on June 2, 1937.

Lennox and Addington County, Buckshot lake-Nest and three eggs in R.O.M.Z. were taken on July 20, 1932 , by C. H. D. Clarke.

Ontario County, Thorah island, Lake Simcoe - Set of seven eggs was found on June 10, 1914, by P. Harrington.

Simcoe County-Eight nests were found (one with three eggs) at Marl lake on June 3 and three nests (one with four eggs) at Orr lake on June 7, 1929 by us. A set of five eggs in R.O.M.Z. was taken at Barrie by H. B. Haugh on June 21, 1916.

Sudbury District-One was seen on nest by us on June 15, 1935 at Chapleau. At Washagami, Davis township, J. B. Walty found a nest with four eggs in early June, 1936. A nest with three eggs and two young, in R.O.M.Z., was taken at Biscotasing by C. E. Hope on June 28, 1937. 
Temiskaming District, Uno Park-Nests, according to Mrs. J. T. Welbourn.

Thunder Bay District-At Port Arthur a set of four eggs was taken on June 23, 1926 , by L. S. Dear. At Rossport a nest with five eggs was secured for R.O.M.Z. on June 4, 1936, by S. C. Downing.

York County, Toronto-A set of five eggs in R.O.M.Z. was taken on May 27, 1905 , by L. B. Brown.

\section{CLIFF SWALLOW PETROCHELIDON ALBIFRONS}

The Cliff or Eave Swallow is an irregularly distributed breeding species in the province, north to southern Sudbury District ${ }^{69}, 110$ and Algonquin Park and Ottawa ${ }^{23}$.

Forster ${ }^{25}$ has recorded it nesting also at Severn river, on Hudson's bay, and consequently it may range throughout the province ${ }^{9},{ }^{44}$. W. Rowan noted also a single individual in July, 1920, at the Manitoba side of Lake of the Woods ${ }^{29}$ and they are known to nest in Lake County, Minnesota ${ }^{176}$ adjacent to Ontario on Lake Superior and at Isle Royale, Michigan ${ }^{49}$.

It is not a common species and its numbers appear to be on the decline in many sections.

Our form is albifrons albifrons.

Elgin County, Port Burwell-Breeds commonly, but was scarce in 1924, according to F. Starr.

Frontenac County-Set of five eggs in R.O.M.Z. was taken at Portsmouth on June 8, 1897, from colony of eight nests by E. Beaupre. At Mountain Grove, R. V. Lindsay took a nest with four eggs (in R.O.M.Z.) on June 26,1932 .

Leeds County, Crosby lake-Nine occupied nests were found on July 7, 1936, by $\mathrm{G}$. C. Toner.

Muskoka District-Two nests were seen on July 8, 1936, by J. M. Speirs at Torrance. At Wasdell Falls, Severn river, D. Hassell and B. Ronald found a colony of thirteen nests on July $13,1936$.

Nipissing District, Brule lake, Algonquin Park-Juvenile male, taken on July 25, 1934, by C. H. D. Clarke, is in R.O.M.Z.

Parry Sound District, Callander-Nests were seen on July 2, 1935 by R.O.M.Z. field party, L. L. Snyder, C. E. Hope and T. M. Shortt.

Simcoe County, Marl lake-Five nests with four and five eggs were found by us on June 3, 1929.

Sudbury District, Bigwood-Nestlings, in R.O.M.Z., were secured from a colony of fourteen nests on July 18, 1937, by C. E. Hope and J. L. Baillie.

Wentworth County, Beverly swamp-33 nests were found on barn on May 30, 1936, by D. Hassell and B. Ronald.

York County, Toronto-Small colony was found breeding on May 11, 1924, by L. L. Snyder. Set of four eggs in R.O.M.Z. was taken on July 21, 1906, by L. B. Brown. 


\section{PURPLE MARTIN PROGNE SUBIS}

The Purple Martin breeds commonly, especially in and about the towns and villages, in southern Ontario, north to Manitoulin District, north Frontenac County and Renfrew County ${ }^{70}$. In extreme western Ontario they breed also at Kenora and possibly elsewhere in Lake of the Woods and Lake Superior districts, wherever habitations offer them suitable breeding places, and they are known to nest at Lake of the Woods (Minnesota ${ }^{176}$ ).

Our form is subis subis.

Elgin County, St. Thomas-Bred commonly in July, 1928, according to F. H. Emery.

Frontenac County-Set of five eggs in R.O.M.Z. was taken at Portsmouth by E. Beaupre on June 18, 1896, and a set of four eggs was also found by Beaupre on June 8,1898 . R. V. Lindsay saw young being fed by parents at Arden in August, 1930.

Kenora District, Kenora-Four families bred in bird box of Mrs. C. Ratchford in 1933, according to B. W. Cartwright, who has a photograph of the colony.

Lincoln County, Niagara-on-the-lake-Set of four eggs was taken on June 22, 1924 , by W. P. Young.

Manitoulin District-About twenty pairs nested at Gore Bay in 1925, according to A. M. Patterson; young were seen in nests about eaves of store on main street. At Treasure island, near Mindemoya, Martins bred in 1936 at Joseph Hodgson's place, according to A. H. Eadie.

Muskoka District, Huntsville-Two or three pairs were found nesting on July 11, 1936, by J. L. Baillie.

Perth County, Listowel-Have nested for forty years on the grounds of H. D. Livingstone, according to W. E. Saunders.

Peterborough County-At Young's Point several pairs bred in boxes at hotel grounds in 1895, according to J. H. Samuel. Egg in R.O.M.Z. was taken at Peterborough between 1896-1899 by G. S. Bell.

Simcoe County-At Barrie a set of five eggs was taken on June 8, 1916, by H. P. Bingham. A. M. Patterson states that four pairs bred in 1936 at Hawkestone, and a nest with four young was found at Midland by R. Standfield on July $17,1935$.

York County, Unionville-E. Dixon has set of three eggs taken there.

\section{CANADA JAY PERISOREUS CANADENSIS}

In the wooded regions of Ontario, the Canada Jay is a familiar and fairly common breeding resident, from Algonquin Park north to Severn river $^{9},{ }^{25},{ }^{133},{ }^{93}$ and Cape Henrietta Maria ${ }^{12}$ (Hudson bay) and west to Kenora ${ }^{44}$ District (D. R. Derry found it to be very common during the summer of 1930 along the Manitoba-Ontario boundary between Lat. $53^{\circ}-54^{\circ}$ N.).

Our form is canadensis canadensis. 
Algoma District, Amyot-Young bird was seen on June 23, 1936 by S. C. Downing, C. E. Hope and J. L. Baillie.

Cochrane District-At Old Woman river, near Kapuskasing, fully grown young were seen on June 6,1925 , by R. D. Ussher, and at Moose Factory it breeds, according to S. Waller, who sent a nest to R.O.M.Z. taken on May 26, 1930 . Another nest in R.O.M.Z. with three eggs, was collected in April, 1936, by F. L. Wilson at Halfway point, between the Moose and Albany rivers.

Kenora District-At Wabigoon a nest with four young was found in April, 1928, by E. R. Norman, according to B. W. Cartwright. At Stull lake, Lat. $54-55^{\circ} \mathrm{N}$. on the Manitoba-Ontario boundary a juvenile was seen by $\mathrm{J}$. Satterly on June 20, 1936.

Muskoka District, Port Sydney-Breeds, according to A. Kay.

Nipissing District, Algonquin Park-Bird was found on nest near Joe lake in May, 1923, by Mrs. A. E. MacLoghlin, according to the Toronto "Globe" of May 31, 1924. At Cache lake, E. L. Brereton found two adults with four young in May, 1936.

Parry Sound District, Frank's bay, Lake Nipissing-Young birds have been found by C. H. D. Clarke.

Sudbury District, Devon, near Chapleau-On June 16, 1937, P. Harrington and J. L. Baillie saw an empty nest, as well as a full-grown juvenile awing.

Temiskaming District, Pork rapids, Montreal river, near Latchford-Juvenile taken on June 10, 1906, by W. B. Rubridge is in collection of J. H. Fleming.

Thunder Bay District-Nest with three eggs (in R.O.M.Z.) was taken on March 13, 1933 and nest with four eggs on April 3, 1933, by L. S. Dear, both in Sibley township. Nest with two young in R.O.M.Z. was taken at Jellicoe on April 22, 1935, by H. M. Parrington.

\section{BLUE JAY CYANOCITTA CRISTATA}

This species is a conspicuous and fairly common summer resident north at least to southern Kenora District ${ }^{29}$ and the Missinabi river ${ }^{12}$ (common in June, 1904). It is much more common in southern Ontario than it is in the north, breeding fairly commonly north to central Sudbury District and Port Arthur and probably throughout its defined range.

Our form is cristata cristata.

Frontenac County-At Sharbot lake, E. Beaupre found a nest with five young on June 18, 1921, and at Kingston on May 12, 1905, he secured a set of four eggs (in R.O.M.Z.).

Huron County, Benmiller-Young bird was taken June 6-7, 1935, by T. M. Shortt.

Kenora District, Kenora-L. Paterson found three young birds on June 15, 1930.

Leeds County, Junetown-Set of four eggs in R.O.M.Z. was taken on May 14, 1902, by W. E. Shelburne.

Lincoln County, St. Catharines-Nest with five eggs was found on June 1, 1935, by G. J. Clout.

Muskoka District, Lake Joseph-Set of five eggs in R.O.M.Z. was secured on June 1, 1892, by J. D. McMurrich. 
Nipissing District-At Eau Claire, young bird was collected on July 1, 1935, by T. M. Shortt and at Lake Wilson, Temagami, O. E. Devitt saw flying young in the summer of 1934 .

Sudbury District, Bigwood-Small young, in R.O.M.Z., were secured by C. E. Hope on July 20, 1937.

Thunder Bay District, Port Arthur-Set of four eggs was taken on May 31, 1929 , by L. S. Dear.

York County-Set of six eggs was taken at Mount Dennis on May 4, 1930, by C. E. Hope. H. H. Brown found a nest with five young at Toronto on May 18, 1888.

\section{RAVEN CORVUS CORAX}

The Raven is a rather rare inhabitant of northern Ontario between Ottawa $^{23}$ and Hudson bay ${ }^{9},{ }^{12}$, west to the Manitoba boundary ${ }^{111}$. It probably nests throughout its range, but the only known nesting records are from Temagami ${ }^{71}$ (nest and three young on cliff at Lake Obakika on June 9, 1909), Moose Factory, Sudbury ${ }^{16},{ }^{81}$, Port Arthur ${ }^{14}$ and southern Kenora District. Roberts ${ }^{176}$ records likely nesting records from Minnesota counties adjacent to western Ontario and it is known to breed on Isle Royale, Michigan ${ }^{49}$. At Lat. $52^{\circ} \mathrm{N}$. on Manitoba side of ManitobaOntario boundary, R. D. Ussher saw six on June 11, 1927.

Our form is corax principalis.

Cochrane District, Moose Factory-Nested regularly in the tall trees of the deep bush, according to S. Waller, who once kept a young one in captivity, secured from brood of three in nest on June 4, 1925, at Hudson Bay Company's logging camp twenty miles south of Moose Factory.

Kenora District, Big Pine lake-Adults were seen feeding young on nest on 150' cliff on May 9 by J. McPhail, according to A. G. Lawrence.

Nipissing District, Hogan lake, Algonquin Park-Formerly nested, according to M. Robinson.

\section{AMERICAN CROW CORVUS BRACHYRHYNCHOS}

The Crow is one of the commonest and most conspicuous summer resident birds of Ontario, ranging north (rarely) to Hudson bay ${ }^{12},{ }^{193}$.

It is known to breed north to southern Kenora District ${ }^{29}$ and Lake Nipigon $^{19}$ and as it also breeds at Churchill, Manitoba ${ }^{9}$, there is every likelihood that it nests throughout the province. D. R. Derry found it to be common during the summer of 1930 along the Manitoba boundary between Lat. $53^{\circ}-54^{\circ} \mathrm{N}$. and at Lat. $52^{\circ} \mathrm{N}$. R. D. Ussher saw a nest with four eggs at Family lakes, Man. on June 9, 1927.

Our crows are brachyrhynchos brachyrhynchos.

Algoma District, Bachawana bay-Adults were seen feeding young on July 11, 1935 , by C. H. D. Clarke. 
Frontenac County-Set of six eggs taken at Kingston on May 6, 1897, by E. Beaupre is in R.O.M.Z. as well as a set of four eggs taken at Wolfe island on June 6,1897 , by C. M. Clarke.

Huron County, West Wawanosh township-Set of five eggs, taken on April 21, 1935 , is in the collection of S. C. Downing.

Kenora District, Ontario side of Indian bay, Lake of the Woods-Bred abundantly in 1920 , according to letter from W. Rowan.

Lincoln County-Nest with four young was found at St. Catharines on May 19, 1935, by G. J. Clout, who also found a nest with four eggs on April 18, 1936, at Decew falls, and a nest with four eggs at St. Catharines on June 20, 1936.

Northumberland County, near Trenton-Set of four eggs taken on April 10, 1921, by W. H. Lunn is in R.O.M.Z.

Prescott County, Hawkesbury-Egg in collection of R. Kirby, was examined by S. C. Downing.

Sudbury District, Chapleau-Two young, in R.O.M.Z., just out of nest, were taken by C. E. Hope on June 16, 1937.

Thunder Bay District, Rossport-Young bird, taken from nest on May 26, 1936, by S. C. Downing, is in R.O.M.Z.

York County-Nest with five eggs was seen at Islington by J. L. Baillie on May 12, 1933. At Toronto, P. Harrington found a nest with four eggs on April 7, 1915, and W. P. Young took a set of four eggs on April 3, 1926.

\section{BLACK-CAPPED CHICKADEE PENTHESTES ATRICAPILlus}

The Chickadee is a fairly common breeding species ${ }^{31}$ of Ontario, from the southern border ${ }^{27}$ north to Fort Albany ${ }^{9},{ }^{12}$ on James bay and west to Lake of the Woods and probably somewhat northward on the Manitoba boundary, as D. R. Derry found it to be common during the summer of 1930 between Lat. $53^{\circ}$ and $54^{\circ} \mathrm{N}$.

In western Ontario, it is said to be represented by the long-tailed race, atricapillus septentrionalis ${ }^{19}$, but the form inhabiting most of the province is atricapillus atricapillus.

Frontenac County, Kingston-Nest with young was found on June 6, 1902, by E. Beaupre.

Kent County, Rondeau-P. Harrington found nest with four eggs on June 12, 1933.

Halton County, Twelve-mile creek-Nest with young was found on June 26, 1926, by T. F. McIlwraith and J. L. Baillie.

Kenora District, Kenora-A nest with five young was found on June 25, 1931, by L. Paterson, according to the Winnipeg "Tribune" of September 12, 1931.

Norfolk County, Turkey Point-Nest with six eggs was seen by J. L. Baillie on May 24, 1937.

Parry Sound District, Emsdale-Set of four eggs taken on May 28, 1893, by J. H. Fleming, is in N.M.C.

Simcoe County - Set of eight eggs was taken on May 10, 1925 and a set of seven eggs on May 9, 1915, by H. P. Bingham at Barrie. At Wasaga beach P. Harrington found a nest with six eggs on June 18, 1920.

Sudbury District, Chapleau-Nest with six young (in R.O.M.Z.) and one egg was found on June 14, 1937, by J. L. Baillie. 
Thunder Bay District-Pair was seen excavating on May 28, 1924 by R. D. Ussher, in the Lake Nipigon region. At Port Arthur L. S. Dear saw a nest with young on June 8, 1924. A brood of six young, in R.O.M.Z. was taken from nest at Peninsula on June 20,1936, by S. C. Downing.

York County, Toronto--Set of seven eggs was taken on May 17, 1929, by F. H. Emery at High Park. Set of seven eggs in R.O.M.Z. was taken at Black creek on May 24, 1905, by L. B. Brown.

\section{BROWN-HEADED CHICKADEE PENTHESTES hUdSONiCUS}

The Brown-headed Chickadee is a not uncommon breeding resident of northern Ontario ${ }^{109}$ from about Lat. $46^{\circ} \mathrm{N}$. north ${ }^{41}$ to Hudson bay ${ }^{9}$; Severn river (on Hudson bay) ${ }^{25}$ being its type locality. It occurs west probably to Lake of the Woods (breeding ${ }^{176}$ in St. Louis County, Minnesota, adjacent to Ontario).

This is the Hudsonian Chickadee of most authors, and the Ontario form is considered to be hudsonicus hudsonicus.

Algoma District-At Saymo lake, Mississagi Forest reserve, nest with eggs was found on July 3, 1928, by D. A. MacLulich. At Amyot, C. E. Hope took four young (in R.O.M.Z.) from nest on July 1, 1936.

Cochrane District, Kapuskasing-Juvenile was collected between June 30 and July 7, 1919, by P. A. Taverner and C. E. Johnson.

Kenora District, Wabigoon-Family was observed on July 1, 1937, by L. L. Snyder.

Nipissing District, Algonquin Park-Juvenile collected on July 22, 1933, by C. H. D. Clarke at Biggar lake is in R.O.M.Z. At Brule lake, Clarke found a nest with young on August 3, 1934 .

Sudbury District, Biscotasing-Young, just out of nest, in R.O.M.Z., was collected by J. L. Baillie on June 28, 1937.

Thunder Bay District, Peninsula-Two sets of six eggs were taken on June 12, 1936, (by P. Harrington) and June 13, 1936, (by C. E. Hope). The latter set is in R.O.M.Z.

\section{WHITE-BREASTED NUTHATCH SITTA CAROLINENSIS}

The White-breasted Nuthatch is a fairly common summer resident of Ontario, occurring north at least to Temagami ${ }^{62}$ and Sudbury ${ }^{16}$. Thompson ${ }^{44}$ gives a record for Kenora, in the Lake of the Woods region. It is much more common in the southern parts of its range, reaching its northern breeding limit, so far as we are aware, in Parry Sound District ${ }^{39}$ and at Ottawa ${ }^{23}$.

Our form is carolinensis carolinensis.

Brant County, Brantford-Set of six eggs is in collection of E. Dixon.

Frontenac County, Kingston-Nest with young (few days old) was found on May 12, 1905, by E. Beaupre.

Lincoln County, St. Catharines-Nest has been found by G. J. Clout. 
Middlesex County, London-Set of eight eggs was taken by W. E. Saunders on April 30, 1902.

Muskoka District, Port Sydney-Breeds, according to A. Kay.

Parry Sound District, Emsdale-Set of six eggs in R.O.M.Z. was taken on May 24,1894 , by J. H. Fleming.

Simcoe County, Barrie-Set of eight eggs was taken on May 9, 1915, by H. P. Bingham.

Welland County, Sherkston-Set of seven eggs taken ${ }^{173}$ on May 10,1896 , by $E$. Reinecke is in N.M.C.

York County-Set of seven eggs was taken on May 25, 1933, by J. L. Baillie at Humber river, Toronto. At King, R. D. Ussher found a nest with young on May 30,1935 , which was vacated on June 9 .

\section{RED-BREASTED NUTHATCH SITTA CANADENSIS}

This small nuthatch may be considered a fairly common summer resident of nearly the whole of Ontario, and certainly from Wellington ${ }^{194}$, Peel and Renfrew Counties to southern Kenora District and Moose Factory ${ }^{12}$. There are instances ${ }^{211}$ of its breeding in St. Lawrence County, New York, adjacent to Ontario. It breeds throughout its range.

Algoma District, Amyot-J. L. Baillie saw parent feeding young on June 27, 1936.

Grey County, Blantyr-Nest was found once in a swamp by C. W. Nash.

Hastings County, Bird creek-Family was seen June 21-24, 1935, by R.O.M.Z. field party, L. L. Snyder and T. M. Shortt.

Kenora District, Rat portage (now Kenora)-Set of six eggs was taken ${ }^{12}$ on May 25, 1903, by W. E. Saunders.

Muskoka District, Port Sydney-Breeds, according to A. Kay, who has found its nest.

Nipissing District, Brule lake, Algonquin Park-Adults were seen feeding young on July 17, 1934, by C. H. D. Clarke.

Peel County, Erindale-Brood of four young, just out of the nest ${ }^{222}$ was found by H. R. Ivor in July, 1933.

Simcoe County, Wasaga beach-Brood of four young (just hatched) was found in nest on June 15,1928 , by P. Harrington.

Thunder Bay District-Set of six eggs was taken from a bird-box at Sibley on June 1,1933 , by L. S. Dear; we saw young birds being fed in the nest at Whitefish lake on June 7, 1935.

\section{BROWN CREEPER CERTHIA FAMILIARIS}

This inconspicuous bird breeds sparingly from Middlesex ${ }^{22}$ and Welland ${ }^{12}$ Counties north ${ }^{15}$ to the transcontinental line of the (C.N.R.) and westward to Lake of the Woods ${ }^{176}$.

Our form is familiaris americana.

Cochrane District, near Kapuskasing-Adult with one young was seen on July 10, 1925, by R. D. Ussher, at Banks lake, Fenton township.

Kenora District, Pistol lake, Minaki-Five young, just out of the nest, were seen with parents in July, 1931, by L. T. S. Norris-Elye and B. W. Cartwright. 
Muskoka District-Young bird taken at Port Sydney on June 21, 1897, by A. Kay is in R.O.M.Z. A set of four eggs in N.M.C. was taken at Gravenhurst on June 24, 1889.

Ontario County, Thorah island, Lake Simcoe - Sets of eggs have been found by J. A. Edwards.

Simcoe County, Barrie - Set of six eggs was taken by H. P. Bingham on May 23, 1915.

Thunder Bay District-Nest with young was found on July 15, 1929, by L. S. Dear at Port Arthur. R. D. Ussher found a nest with five eggs on June 4, 1924, on Sturgeon river, south of Turkey lake, near Lake Nipigon. At Peninsula, P. Harrington collected a nest with five eggs on June 13, 1936.

\section{HOUSE WREN TROGLODYTES AEDON}

The House Wren is a common breeding summer resident of Ontario (rather sparingly in the north) from the southern border at least to Lake Abitibi ${ }^{31}$ and west to Lake of the Woods ${ }^{176}$.

In north-western Ontario the breeding race is probably aedon parkmani $i^{19}$, but the form inhabiting most of Ontario is considered to be aedon aedon.

Algoma District, Bachawana bay-Nest with young was seen on July 12, 1935, by C. H. D. Clarke.

Frontenac County-Set of five eggs in R.O.M.Z. was taken at Portsmouth on June 12,1898 , by E. Beaupre and a nest with seven eggs in R.O.M.Z. was taken at Arden by R. V. Lindsay on July 7, 1926.

Huron County, West Wawanosh township-Set of five eggs, in collection of S. C. Downing, was taken on July 21, 1935.

Kenora District, Ontario side of Indian bay ${ }^{29,}{ }^{190}$, Lake of the Woods-Not plentiful breeder in 1920, according to letter from W. Rowan.

Kent County, Rondeau-Nest with seven eggs was found by us on June 7, 1933.

Parry Sound District-Was seen feeding young in nest on July 18, 1933, by H. K. Gordon, at Point au Baril. At Pickerel lake, near Burk's Falls, J. L. Baillie found a nest with five eggs on July 18, 1936.

Sudbury District, Bigwood-Seven young, in R.O.M.Z., were taken from nest by J. L. Baillie on July $26,1937$.

Temiskaming District, Uno Park-Raised two broods in bird-boxes, according to Mrs. J. T. Welbourn.

Thunder Bay District-Old nest was seen by us on June 3, 1935, at Silver mountain; L. S. Dear took a nest with six eggs at Port Arthur on July 22, 1922.

York County-At Pottageville a nest was found by R. D. Ussher on May 24, 1935, with one egg. It contained four eggs on June 2. A set of three eggs in R.O.M.Z. was taken at Centre island on July 8, 1906, by L. B. Brown.

\section{WINTER WREN NANNUS HIEMALIS}

This dweller of the deep woods and swamps is found in small numbers from Middlesex ${ }^{22}$ and Leeds Counties north to Moose Factory ${ }^{12}$ and west to Manitoba. 
It probably nests throughout its range $\mathrm{e}^{18}$ as it is known to nest north and west to Lac Seul and the Minnesota boundary ${ }^{176}$ and it was noted (not very commonly) by D. R. Derry during the summer of 1930 on the Manitoba Ontario boundary between Lat. $53^{\circ}$ and $54^{\circ} \mathrm{N}$.

Our form is hiemalis hiemalis.

Algoma District, Kindiogami lake, Township 3B or 3C, Mississagi Forest reserve - Nest with five eggs was found on July 12,1923 , by R. D. Ussher.

Frontenac County, Mountain Grove-Young were seen being fed by parents on July 8,1926 , by R. V. Lindsay.

Kenora District, Lac Seul-Young bird taken on July 30, 1919, by D. Blakely is in N.M.C.

Middlesex County, Komoka-Young bird was taken by W. E. Saunders on August 23, 1888.

Nipissing District, Algonquin Park, Biggar lake-Young were seen on August 8, 1932, by C. H. D. Clarke.

Parry Sound District, Frank's bay, Lake Nipissing-Young were seen being fed by parents on June 19, 1933, according to C. H. D. Clarke.

Simcoe County, Cranberry lake-Young bird was taken from brood by us on June 5, 1929.

Thunder Bay District, Port Arthur-Set of six eggs was taken on June 1, 1933, by L. S. Dear.

Waterloo County, near Waterloo-On June 28, 1936, R. C. Brooman found a group of young, scarcely able to fly.

Victoria County, Bobcaygeon-Young just out of the nest were found on June 11, 1933 , by F. Starr.

\section{CAROLINA WREN THRYOTHORUS LUDOVICIANUS}

The Carolina Wren is an irregular and uncommon resident of the more southern parts of the province, north to Lambton County ${ }^{12}$ and east to Victoria County (one in R.O.M.Z. taken at Woodville on October 29, 1930 , by F. Starr), and Northumberland County (one seen at Brighton by C. J. Young on October 2, 1918). Actual breeding records are known only from Essex (two juveniles collected ${ }^{195}$ on September 6, 1905) and York Counties $^{72}$ (nest with two eggs and two young found on May 18, 1930) but the species may breed anywhere within its range.

Ontario Carolina Wrens are referred to ludovicianus ludovicianus.

Essex County, Pelee island-New nest was found by us on June 4, 1933, and we were informed that a pair raised a brood in a barn there in 1932.

\section{LONG-BILLED MARSH WREN TELmatodytes PALUstris}

This is a common breeder in the cat-tail marshes of southern Ontario ${ }^{141}$ north to Simcoe, Peterboro and Renfrew Counties ${ }^{12},{ }^{23}$ and also at Lake of the Woods ${ }^{29},{ }^{190}$. In eastern Ontario the most northern 
summer occurrence of which we are aware is near Callander, where it was seen on June 8, 1924 by W. E. Ricker.

The form occurring in this province is recognized as the Prairie Marsh Wren, palustris dissaeptus.

Frontenac County, Kingston-Set of seven eggs in R.O.M.Z. was taken on June 6,1900 , and second set of four eggs on June 20, 1898, by E. Beaupre.

Huron County, Brussels-Nest has been found by C. H. D. Clarke.

Kenora District, Ontario side of Indian bay, Lake of the Woods-Nested abundantly in 1920, according to letter from W. Rowan.

Kent County, Rondeau-Set of six eggs taken on June 9, 1914, by A. A. Wood is in R.O.M.Z.

Lincoln County - Set of six eggs in R.O.M.Z. was taken at Grimsby on June 10, 1889 , by J. L. Jackson. G. J. Clout discovered a nest with three eggs at Niagara-on-the-lake on July 11, 1936.

Ontario County, Simcoe Point, Pickering-Nest with six eggs was found on June 3, 1935, by R. A. Smith.

Peterborough County, Lakefield-Nest was found on July 7, 1923, by J. L. Baillie.

Simcoe County-At Otter lake, O. E. Devitt and R. A. Smith found a set of six eggs on June 19, 1935. H. P. Bingham took a set of five eggs at Little lake on August 15, 1915.

Victoria County-Nest (in R.O.M.Z.) with two deserted eggs was found at Downeyville on October 12, 1931, by H. H. Southam. At Bobcaygeon a nest with one egg was found on June 4, 1932, by F. Starr and P. Harrington.

York County, Toronto-Set of five eggs was taken by P. Harrington on May 27, 1922 , and set of six eggs in R.O.M.Z. was taken on July 1, 1892, by J. L. Jackson. Set of eight eggs in R.O.M.Z. was taken at Ashbridge's bay on June 11, 1904, by L. B. Brown.

\section{SHORT-BILLED MARSH WREN CISTOTHORUS STELLARIS}

This wren is locally distributed in Ontario from the southern border ${ }^{141},{ }^{143}$ north to Kenora ${ }^{29},{ }^{176},{ }^{190}$, and southern Sudbury Districts and Carleton County ${ }^{23}$. It is fairly common but irregular, breeding throughout its range.

Kenora District, Ontario side of Indian bay, Lake of the Woods-Bred plentifully in 1920, according to letter from W. Rowan.

Norfolk County, Turkey Point-Nest with six young was found on August 23, 1936, by S. L. Thompson.

Northumberland County, Colborne-Nest was found in July, 1935, by W. H. Lunn.

Ontario County-At Simcoe Point, Pickering, a nest with seven young was found on June 30,1935 , by O. E. Devitt, the nest and two of the young are in R.O.M.Z., taken on July 5. W. H. Lunn saw a pair with six nearly grown young on July 23,1936 , at Blackwater Junction.

Simcoe County-Set of eight eggs was taken at Cranberry lake on June 12, 1929, by P. Harrington; at Marl lake O. E. Devitt took a set of seven eggs on July 15,1934 , which is in R.O.M.Z. 
Sudbury District, Bigwood-Dummy nest was found on July 19, 1937, by C. E. Hope.

Thunder Bay District, Whitefish lake-Set of seven eggs was taken on June 16, 1929 , by L. S. Dear.

Victoria County - Set of eight eggs was taken at Woodville on June 11, 1930, by F. Starr. P. Harrington took a set of five eggs at Fenelon Falls on June 5, 1931.

Wentworth County, Hamilton-Several young were seen on July 5, 1934, by G. North.

York County, Holland river marsh-Nests with four young and five eggs were found on July 18, 1937, by D. Ross and F. Barratt, respectively. The latter nest, with three eggs, is in R.O.M.Z.

\section{MOCKINGBIRD mimus POLYGLOTTOS}

This bird is very rare and except for an accidental record at Moose Factory $^{73}$ (June 4, 1928) is found only in extreme southern Ontario ${ }^{74}$ north and east to Middlesex ${ }^{22}$ and Durham Counties ${ }^{75}, 225$.

It has been found breeding on but four occasions, three in Essex ${ }^{49}$ and the other in Haldimand County.

Our race is the eastern Mockingbird, polyglottos polyglottos.

Essex County, Point Pelee-A. Gardner reported a pair nesting in 1909, according to the journals of W. E. Saunders.

Haldimand County, Nanticoke-Pair nested 8 feet up in a large thorn tree in 1924 , according to C. D. Wedrick. The nest contained five eggs when found but only three young were reared.

\section{CATBIRD DUMETELLA CAROLINENSIS}

The Catbird is a common summer resident of Ontario north to southern Kenora ${ }^{29}$ and Sudbury District, breeding throughout its range. There is a specimen from Temagami (Nipissing District) in R.O.M.Z. taken on September 8, 1934, by A. F. Coventry.

Essex County, Point Pelee-Nest and set of three eggs in R.O.M.Z. were taken on July 6, 1920, by L. L. Snyder.

Frontenac County-Set of four eggs in R.O.M.Z. was taken at Portsmouth on May 17, 1895, by E. Beaupre, and set of four eggs in R.O.M.Z. was taken by E. Beaupre at Wolfe island on June 8,1900 .

Kenora District, Kenora-Nest with four eggs was found on July 20, 1932, by L. Paterson.

Lincoln County, St. Catharines-G. J. Clout found a nest with four eggs on June $2,1934$.

Northumberland County, near Trenton-Set of four eggs in R.O.M.Z. was taken on June 15, 1921, by W. H. Lunn.

Peel County, Erindale-Nest with four eggs was found on June 3, 1935, by O. E. Devitt and nest with young was seen by J. L. Baillie on June 27, 1934. 
Simcoe County - Nest with four eggs (in R.O.M.Z.) was taken at Little lake on May 28, 1919, by H. P. Bingham, and P. Harrington secured a set of four eggs on July 27, 1915, at Wasaga beach.

Sudbury District, Bigwood-Nest with four young was found by F. Starr on June 24, 1914, and C. E. Hope collected young, out of the nest, on July 16 , 1937, for R.O.M.Z.

Wellington County, Guelph Junction-W. E. Saunders has a set of five eggs taken on June 5, 1912.

York County, Toronto-Nest and four eggs in R.O.M.Z. was taken on May 21, 1905 , by L. B. Brown and nest with four eggs was found on June 25, 1934, at Mount Dennis by C. E. Hope, who also found a nest with young just hatching there on August 12, 1934.

\section{BROWN THRASHER TOXOSTOMA RUFUM}

The summer distribution of the Brown Thrasher in Ontario lies almost entirely south of the latitude of Lake Nipissing ${ }^{104},{ }^{127}$ and Ottawa. It is a fairly common species and breeds. Langille ${ }^{127}$ has recorded that it was very common on Manitoulin island (northern Lake Huron) in June, 1881, but we are aware of no definite nesting record for that district, and the same may be said for Cabot's observation ${ }^{82}$ of the species at Pic, Thunder Bay District, in the summer of 1848, although it is numerous in sections of the south shore of Lake Superior ${ }^{49}$, in Michigan, according to Barrows. The species was noted several times in early June, 1936, at Washagami, Sudbury District, by J. B. Walty.

Carleton County, Mer Bleue-Set of four eggs in N.M.C. was taken on June 5, 1932 , by C. E. Johnson.

Essex County-Set of three eggs was taken on July 19, 1920, by L. L. Snyder at Point Pelee; we saw a nest with young at Scudder, Pelee island, on June 5, 1933. On May 18, 1918, W. E. Saunders found a nest with four eggs, plus Cowbird's egg, at Point Pelee.

Frontenac County-Set of five eggs (three in R.O.M.Z.) was taken at Kingston on May 15, 1900, by E. Beaupre. At Arden, R. V. Lindsay found a nest with four eggs on July 8, 1926.

Lambton County, Port Franks-Nest with four eggs was found on May 27, 1928 , by G. W. Knechtel.

Lincoln County, St. Catharines-Nest with three eggs was found by G. J. Clout on June $10,1934$.

Muskoka District-Nest with two eggs in R.O.M.Z. was taken by A. Kay at Port Sydney. At Robinsdale, A. W. Needler photographed a nest with four eggs on June 12, 1923.

Parry Sound District-At Katrine, nest with three eggs was found in 1929, by R. J. Rutter. Two adults with young were seen at Frank's bay, Lake Nipissing, on July 23, 1934, by D. A. MacLulich.

Sudbury District, Bigwood-Young, just out of nest, in R.O.M.Z., were secured by C. E. Hope on July 17, 1937.

Wentworth County, Hamilton-A nest with four eggs was found in May, 1936, by $\mathrm{P}$. Henderson. 
York County-Set of five eggs was secured at Toronto on May 15, 1914, by P. Harrington, and a set of two eggs in R.O.M.Z. was taken at Scarboro junction on June 21,1887 , by J. L. Jackson.

\section{AMERICAN ROBIN TURDUS MIGRATORIUS}

The Robin is one of the commonest and most widely-distributed of Ontario birds, nesting everywhere throughout the province ${ }^{9},{ }^{25}$ north at least to Moose Factory at the south end of James bay and Severn river ${ }^{193}$, on the south shore of Hudson's bay. It was found uncommonly during the summer of 1930 along the Manitoba boundary (between Lat. $53^{\circ}-54^{\circ}$ N. by D. R. Derry) which probably marks its western breeding limit in the province.

It is most common near habitations and is therefore comparatively scarce in large areas of northern Ontario.

Our form is the eastern Robin, migratorius migratorius.

Algoma District, Amyot-Nest with four eggs, taken on June 23, 1936, by S. C. Downing, is in R.O.M.Z.

Cochrane District-At Moose Factory a nest with four eggs was found by S. Waller on June 25, 1930. R. V. Whelan found a nest with three eggs on June 13, 1936, at Smoky Falls, north of Kapuskasing.

Durham County, Hampton-Set of five eggs was found on August 7, 1930, by A. E. Allin.

Essex County - Nest with three eggs was found by us at Pelee island on June 5, 1933. A set of four eggs in R.O.M.Z. was taken at Point Pelee by L. L. Snyder on July $3,1920$.

Frontenac County, Kingston-Set of four eggs taken on April 28, 1897, by C. K. Clarke is in R.O.M.Z.

Grey County, Meaford-Nest with eggs was found on April 19, 1936, by L. H. Beamer.

Kenora District, Kenora-A nest with four eggs was found on June 18, 1930, by L. Paterson, according to B. W. Cartwright.

Simcoe County-At Barrie H. P. Bingham took a set of four eggs (in R.O.M.Z.) on May 5, 1920, and at Wasaga beach P. Harrington found a nest with three eggs on July 27, 1914. At Minesing, J. L. Baillie found a Cowbird's egg in the nest of this species on May 21, 1932.

Thunder Bay District-Nest with five eggs was found by us on May 31, 1935, at Whitefish lake; L. S. Dear took a set of four eggs at Port Arthur on May $23,1924$.

York County-At Toronto, nest with four eggs was found in Don valley on April 21, 1929, by N. Smith, nest with five eggs at Laing street on April 24, 1933 , by H. H. Southam, nest with three eggs on June 18, 1891, by J. L. Jackson, and nest with young on August 12, 1937, by J. L. Baillie. At King, R. D. Ussher found a nest with one egg on July $25,1935$.

\section{WOOD THRUSH HYLOCICHLA MUSTELINA}

This thrush cannot be considered a common summer resident of Ontario, excepting in the extreme south-western peninsula. 
Elsewhere in this province it is found in small numbers, breeding from Iakes Erie and (Ontario north to Parry Sound District ${ }^{160}$ and Ottawa ${ }^{113}$. There is a record of its occurrence at Sault Ste. Marie ${ }^{95}$ and Rev. J. H. Iangille considered them to be common ${ }^{127}$ in June, 1881 , at the LaCloche mountains, Manitoulin District, but breeding evidence is not at hand for either of these localities. It occurs occasionally in summer at Frank's Bay, Lake Nipissing, Parry Sound District, according to C. H. D. Clarke, and there is a specimen in R.O.M.Z. taken on June 30, 1935, at Eau Claire, Nipissing District.

Frontenac County, Kingston-E. Beaupre found sets of four eggs on May 25, 1904, and June 11, 1905.

Grey County, Craigleith-Set of five eggs was taken by us on June 9, 1928.

Kent County, Rondeau-Set of three eggs was taken by us on June 13, 1933.

Middlesex County, Coldstream-There is a set of four eggs in R.O.M.Z. taken by A. A. Wood on June 10, 1917.

Muskoka District, near Fox Point, Lake of Bays-A family group was seen by T. F. McIlwraith in early August, 1932.

Nipissing District, Brule lake, Algonquin Park-Adults were seen feeding young on July 4, 1934, by C. H. D. Clarke.

Perth County, Listowel-A set of four eggs in R.O.M.Z. was taken on May 20, 1902, by A. A. Perrin.

Simcoe County-H. B. Haugh took a nest and four eggs (in R.O.M.Z.) at Barrie on June 14, 1918, and P. Harrington took a set of two eggs (in R.O.M.Z.) at Wasaga beach on July $23,1914$.

Wentworth County, Hamilton-Parent was seen on four eggs on May 28, 1933, by D. Hassell and B. Ronald.

York County, Wychwood Park, Toronto-Small young were seen by Margaret $\mathrm{H}$. Mitchell in the summer of 1933, and J. A. Edwards examined a nest with three eggs at the same place on June $18,1909$.

\section{HERMIT THRUSH HyLOCICHLA GUTTATA}

The Hermit Thrush is a fairly common summer resident of the central and more unsettled parts of the province, from Halton ${ }^{76}$ and Leeds ${ }^{12}$ Counties to the transcontinental line of the Canadian National Railway $^{8},{ }^{29},{ }^{31}$ and probably north to James bay (two specimens in R.O.M.Z. taken at Moose Factory on May 17, 1930, by S. Waller).

It is known to breed from Halton and Leeds Counties, north and west to Lake of the Woods ${ }^{176}$, Thunder Bay and Algoma Districts, and it probably nests throughout its summer range.

Our form is the Eastern Hermit Thrush, guttata faxoni.

Algoma District, Township 4A, Mississagi Forest reserve-Nest with four eggs was found on June 11, 1923, by R. D. Ussher.

Hastings County-Set of three eggs taken on May 26, 1926, by E. Beaupre at Madoc is in R.O.M.Z., as are also nest and three eggs taken at Bird creek on June 23, 1935, by L. L. Snyder. 
Kenora District, Pistol-Worth lakes portage, near Minaki-Nest with four eggs was found on July 1, 1931, by R. Norris-Elye, according to B. W. Cartwright.

Leeds County, Junetown-Nest with three eggs was found by E. Beaupre on June 11, 1901. The eggs are in R.O.M.Z.

Muskoka District, Torrance-J. M. Speirs saw a nest on July 15, 1937, containing two eggs.

Parry Sound District-Nest with three eggs in R.O.M.Z. was found on May 31, 1933, by C. H. D. Clarke at Frank's bay, Lake Nipissing. A set of four eggs in R.O.M.Z. was collected by J. H. Fleming at Emsdale on May 17, 1897.

Renfrew County, Petawawa-Nest with two young and one imbedded Cowbird's egg was found on June 1, 1916, by P. Harrington.

Sudbury District, Cartier-F. Starr found a nest with eggs on May 24, 1936.

Temiskaming District, North Cobalt-Set of four eggs was taken on May 21, 1919, by J. A. Edwards.

Thunder Bay District-At Port Arthur, a set of four eggs was taken on June 3, 1923 , by L. S. Dear. J. L. Baillie collected a nest with three young at Peninsula on June 18, 1936, now in R.O.M.Z.

\section{OLIVE-BACKED THRUSH HYLOCiCHLA USTULATA}

The Olive-backed Thrush is of more northern distribution than the Hermit Thrush, occurring commonly in summer from southern Georgian bay and northern Hastings County to the southern edge of James bay. It breeds throughout its range, west to southern Kenora District and undoubtedly to Lake of the Woods ${ }^{29},{ }^{176}$ where it was found during the summer of 1920 on the Ontario side of Indian Bay, according to letter from W. Rowan. Also, it was a fairly common resident during the summer of 1930 , according to D. R. Derry, along the Manitoba-Ontario boundary between Lat. $53^{\circ}-54^{\circ} \mathrm{N}$., and R. D. Ussher found a nest with three young on July 2,1927 , at Fishing lake, Manitoba, at Lat. $52^{\circ} \mathrm{N}$. on the same boundary.

The race of eastern North America is ustulata swainsoni.

Algoma District-Nest with two eggs was found at Franz on June 24, 1924, by M. M. Green. R. D. Ussher found a nest with three eggs on June 21, 1923, at Mississagi Forest reserve, between Green lake and Abinette river, townships $4 \mathrm{~B}$ and $4 \mathrm{~A}$. At Amyot, C. E. Hope took a nest with one egg and three young on July 2, 1936, now in R.O.M.Z.

Cochrane District-A nest with three eggs was taken on June 27, 1930, at Moose Factory by S. Waller (in R.O.M.Z.), E. Dixon has eggs secured at Lake Abitibi by A. V. Dukes and P. A. Taverner and C. E. Johnson secured a juvenile in the summer of 1919 at Kapuskasing.

Haliburton District, Haliburton-P. Harrington has a set of three eggs taken on June 15, 1918.

Hastings County, Bird creek-Nest with three eggs in R.O.M.Z. was found on June 22,1935 , by C. E. Hope.

Kenora District, Wabigoon-Nest with four eggs was found by T. M. Shortt on June 21, 1937. 
Manitoulin District, McGregor bay-Set of three eggs in R.O.M.Z. was taken on June 11, 1921, by B. A. Bensley.

Muskoka District-At Robinsdale, a nest with two eggs was found on June 10, 1923 , by A. W. Needler, and at Lake Joseph, R. D. Ussher saw young leaving nest on July 21, 1922.

Nipissing District-Nest with eggs was found on June 19, 1928, by A. F. Coventry at Temagami. At Eau Claire, C. E. Hope took a nest with three young (in R.O.M.Z.) on July 1, 1935.

Sudbury District, Chapleau-Nest and four eggs, in R.O.M.Z., were taken by C. E. Hope on June 8, 1937.

Thunder Bay District, Port Arthur-Set of four eggs was taken on June 13, 1931, by L. S. Dear.

\section{WILSON'S THRUSH HYLOCICHLA FUSCESCENS}

In summer, the Wilson's Thrush inhabits Ontario from the southern border north at least to southern Sudbury District ${ }^{64},{ }^{104}$ and Ottawa ${ }^{23}$, breeding throughout its range. It breeds in fair numbers also in southern Thunder Bay and southern Kenora Districts ${ }^{29}$. It is a common species, especially in the southern parts of its range, and probably extends somewhat farther north than the actual nesting records indicate. In this connection, it is of interest to note that C. H. D. Clarke observed the species during the summer of 1935 at Goulais bay, on the east shore of Lake Superior, and J. B. Walty noted its presence in June, 1936 at Washagami, Sudbury District.

The form occupying extreme western Ontario (southern Kenora and Rainy River Districts) may be fuscescens salicicola, although Taverner states that fuscescens fuscescens "extends west probably to near the Manitoba border and perhaps across it." This is the Veery of most authors, the race occupying most if not all of Ontario being fuscescens fuscescens.

Carleton County, Billings' bridge-Set of five eggs, plus egg of Cowbird, in N.M.C. were taken by C. E. Johnson on June 5, 1916.

Frontenac County - Set of three eggs in R.O.M.Z. was taken at Kingston on May 8, 1897, by C. K. Clarke; set of four eggs in R.O.M.Z. was found at Sharbot lake on June 6, 1905, by E. Beaupre.

Grey County, Craigleith-Nest with two eggs was found by us on June 9, 1928.

Haliburton District, Dysart township-A nest with three eggs was found on July 2, 1935, and a nest with four eggs on June 6, 1936, by E. W. Calvert.

Kenora District, Kenora ${ }^{180}$ - Nest with four eggs was found on July 1, 1931, by L. Paterson, according to the "Winnipeg Tribune" of September 12, 1931.

Nipissing District, Eau Claire-Nest and three eggs in R.O.M.Z. were taken on July 1, 1935, by T. M. Shortt.

Simcoe County-Set of four eggs was taken at Minesing by us on June 4, 1929, and a nest with three eggs in R.O.M.Z. was taken at Little lake on July 3, 1918 , by H. B. Haugh. 
Sudbury District, Bigwood-Young, in R.O.M.Z., was taken on July 15, 1937, by J. L. Baillie.

Thunder Bay District, Port Arthur-Set of four eggs was found on July 1, 1924, by L. S. Dear.

York County, Toronto- $\mathrm{P}$. Harrington found nest with two eggs plus cowbird egg (in R.O.M.Z.) at Toronto on May 17, 1922, and a set of three eggs in R.O.M.Z. was secured on June 25, 1892, by J. L. Jackson. At Armour heights, C. E. Hope took a nest with three eggs plus four Cowbird's eggs (in R.O.M.Z.) on June 1, 1932.

\section{RED-BREASTED BLUEBIRD SIALIA SIALIS}

The Bluebird is a fairly common summer resident of southern settled Ontario, breeding north at least from the southern border to the transcontinental line of the Canadian National Railway ${ }^{31}$ west to southern Kenora District.

There are summer occurrences north to Moose Factory ${ }^{12}$, but it is comparatively rare everywhere north of Lake Nipissing.

Our form is sialis sialis.

Frontenac County, Portsmouth-Set of five eggs in R.O.M.Z. was found on May 14, 1902, by E. Beaupre.

Huron County, West Wawanosh township-Set of five eggs was taken on July 10,1935 , according to R. Smyth.

Kenora District, Wabigoon-Nest was found by T. M. Shortt on June 18, 1937.

Lincoln County-At Rosedene a nest with five eggs was found on May 7, 1933, by G. J. Clout and at Beamsville a nest with five eggs was found on May 5, 1918, by H. M. Laing, according to the "Globe" May 18, 1920.

Muskoka District-Set of five eggs was photographed at Robinsdale on June 7, 1923 , by A. W. Needler. Set of four eggs in R.O.M.Z. was taken on July 15, 1919, by L. L. Snyder at Port Sydney.

Northumberland County, Wooler-Nest with four eggs was found by R. V. Lindsay on July $26,1925$.

Simcoe County-Nest with four eggs was found on May 5, 1915, at Barrie by H. P. Bingham. At Wasaga beach, a set of three eggs was taken on June 21, 1924, by P. Harrington.

Sudbury District, Chapleau-Nest with five eggs was found by P. Harrington on June 16, 1937.

Thunder Bay District, Port Arthur-Nest with five eggs was found on June 24, 1928 , by L. S. Dear and nest with young on June 1, 1928, by the same observer.

York County-Nest with five eggs was found at Toronto on April 17, 1915, by P. Harrington and nest with young at Pottageville on August 11, 1928, by J. L. Baillie.

\section{BLUE-GRAY GNATCATCHER POLIOPTIlA CAERUlEA}

This is a very rare breeding summer resident of extreme southern Ontario, south of Middlesex and Durham Counties. The most northern 
records of its occurrence are Sault Ste. Marie ${ }^{95}$, Algoma District, Goderich, Huron County (one seen on May 18, 1929, by C. H. D. Clarke), Sarnia, Lambton ('ounty (one in R.O.M.Z. taken on June 25, 1900), by John Boyd) and it has been known to occur ${ }^{49}$ at Mackinac island, between northern Lake Huron and Lake Michigan, Michigan.

Formerly it was not uncommon ${ }^{22}$ in certain of the extreme southwestern counties, and at a wood near London W. E. Saunders once found three nests in a single morning.

Our form is caerulea caerulea.

Durham County, Bowmanville-Nest was found in crotch of an apple tree on May 24, 1932, by J. H. Jennings. A brood was subsequently raised.

Elgin County, Aylmer-Nest with three eggs in R.O.M.Z. was taken on May 14, 1897, by R. T. Anderson.

Middlesex County, London-W. E. Saunders found his first nest about 1874 .

Waterloo County, Galt-A nest with young (parents feeding) was found on June 27,1934 , by G. W. Knechtel.

\section{GOLDEN-CROWNED KINGLET REGULUS SATRAPA}

This kinglet is apparently an uncommon summer resident of Ontario, from the southern border ${ }^{22}$ north at least to the transcontinental line of the C.N.R. ${ }^{31}$ and west to Thunder Bay District (and probably Lake of the Woods ${ }^{176}$ ) breeding throughout its range.

It is probably much more common in summer than the few breeding records would indicate and its nesting range more than likely includes the whole of the province ${ }^{9}$.

The Ontario race is satrapa satrapa.

Algoma District, Bachawana bay-C. H. D. Clarke saw adults feeding young on July 18, 1935 .

Frontenac County, northern part-Nest and seven eggs in N.M.C. were taken on May 27, 1904, by C. J. Young.

Muskoka District, Port Sydney-Breeds, according to A. Kay, who collected a male on July 5, 1898.

Nipissing District, Brule lake, Algonquin Park-C. H. D. Clarke saw adults feeding young on July 16, 1934 .

Peel County, Credit Forks-Brood of young was found on July 2, 1933 by C. E. Hope. One was secured.

Simcoe County, Wasaga beach-Nest in R.O.M.Z. was found by us on June 8, 1929.

Sudbury District, Biscotasing-Young, in R.O.M.Z., was collected by C. E. Hope on June 30, 1937.

Thunder Bay District-Nest with young was found on July 2, 1926, by L. S. Dear at Port Arthur. R. D. Ussher saw adults with young out of the nest in July, 1924, in the vicinity of Lake Nipigon.

York County, King township-Nestling, in R.O.M.Z., was taken from brood of five in nest on June 16, 1937, by R. D. Ussher. 


\section{RUBY-CROWNED KINGLET CORTHYLIO CALENDULA}

The Ruby-crowned Kinglet is apparently an uncommon summer resident of the whole of Ontario ${ }^{9},{ }^{78}$.

It probably breeds throughout Ontario, much more regularly and commonly, however, north of Muskoka District ${ }^{17}$. It was considered common $^{12}$ at Moose Factory on James bay, on June 9, 1896, and R. D. Ussher saw a pair feeding young on July 15,1927 , at Lat. $52^{\circ} \mathrm{N}$. on the Manitoba side of the Manitoba-Ontario boundary.

Our race is calendula calendula.

Cochrane District, Banks lake, Fenton township, near Kapuskasing-Pair was seen feeding young out of the nest on July 13, 1925, by R. D. Ussher.

Kenora District, Kenora-Female was seen feeding five young just out of the nest on July 18,1932 , by L. Paterson, according to B. W. Cartwright.

Muskoka District, Port Sydney-Breeds rarely, according to A. Kay.

Parry Sound District, Sundridge-Young were seen in July, 1931, by J. M. Speirs.

Sudbury District-Nest with eight eggs was taken by P. Harrington on June 10, 1937, at Chapleau. At Biscotasing, C. E. Hope took four young, just out of nest, for R.O.M.Z., on July 9, 1937.

Thunder Bay District-At Port Arthur, a nest (in R.O.M.Z.) with eight eggs was found on June 3, 1934, by L. S. Dear. At Peninsula, a nest with nine eggs was secured on June 18, 1936, by P. Harrington.

\section{CEDAR WAXWING BOMBYCILLA CEDRORUM}

This is a common summer resident of Ontario, breeding north at least to the south end of James bay ${ }^{12},{ }^{19}$ and west to Lake of the Woods ${ }^{29}$ 176. D. R. Derry saw them frequently during the summer of 1930 along the Manitoba-Ontario boundary, between Lat. $53^{\circ}-54^{\circ} \mathrm{N}$.

Algoma District, Bachawana bay-Young were seen being fed by parents on July 28,1935 , by C. H. D. Clarke.

Cochrane District-Juveniles were seen at Kapuskasing in August, 1928, by W. J. Garnett and at Moose Factory a nest with seven eggs was found in 1929 by S. Waller.

Durham County, Hampton-Young were seen to leave nest on September 5, 1931, by A. E. Allin.

Elgin County, Port Burwell-Set of three eggs was taken on June 23, 1924, by F. Starr.

Huron County, West Wawanosh township-Set of five eggs, plus Cowbird's egg, were taken on July 14,1935 , according to R. Smith.

Kenora District, Kenora-Breeds, according to Mrs. C. Ratchford, and L. Paterson found a nest with two young there.

Renfrew County, Petawawa-Nest with four eggs in R.O.M.Z. was taken on June 26, 1935, by C. E. Hope.

Sudbury District, Bigwood-Set of five eggs was taken on June 29, 1914, by F. Starr, and C. E. Hope secured a brood of five nestlings (in R.O.M.Z.) on July $22,1937$. 
Thunder Bay District, Port Arthur-Set of four eggs was taken on August 2, 1922, by L. S. Dear, who also found a nest with four eggs on June 19, 1914.

York Count y-At Don river, a nest with young (one taken) was seen on September 13,1936 , by R. J. Rutter, and a nest with two eggs in R.O.M.Z. was taken at Lambton on June 14, 1905, by L. B. Brown.

\section{COMMON SHRIKE LANIUS LUDOVICIANUS}

In the cultivated areas of southern Ontario, north to Lake Nipissing and Ottawa ${ }^{23}$, this shrike is a rather uncommon summer resident, breeding wherever it occurs. One was seen at Mindemoya, Manitoulin District, on August 6, 1934, by J. M. Speirs. Since it is known to occur also in Manitoba ${ }^{77}$, it may breed in the Lake of the Woods district of extreme western Ontario.

This is the Migrant Shrike of most authors, and our form is ludovicianus migrans.

Frontenac County, Kingston-This is the type locality of this sub-species. Set of seven eggs was found by E. Beaupre on April 23, 1898.

Grenville County, Algonquin-Set of six eggs, in R.O.M.Z., was taken on May 11, 1937, by S. C. Downing.

Grey County, Redwing-Nest with five small young was found on June 1, 1930, by R. V. Lindsay.

Huron County, Brussels-Set of four eggs was found on April 26, 1924, by C. H. D. Clarke.

Lambton County, Sarnia-Young bird in R.O.M.Z. was taken on June 25, 1900, by J. Boyd.

Nipissing District, Rutherglen-Young was taken on July 2, 1935, by C. E. Hope.

Simcoe County-Nest with one egg was seen on April 28, 1935, at Bradford by R. A. Smith. It contained five eggs on May 13. A set of four eggs in R.O.M.Z. was taken at Barrie by H. P. Bingham on July 9, 1917. Brood of four young, attended by parents, was seen by Rodger Standfield on August 15, 1936, at Martyr's Shrine, near Midland.

Welland County, near Port Colborne-Set of six eggs was taken on May 15, 1925 , by W. P. Young.

Wentworth County, Hamilton-On May 30, 1923, R. O. Merriman saw a nest containing two large young and one egg.

York County, Toronto-Set of three eggs was taken on April 14, 1922, by P. Harrington. Downy young was seen on Eglinton avenue on July 9, 1898, by J. H. Samuel.

\section{COMMON STARLING STURNUS VULGARIS}

Since the advent of the Starling in Ontario in 1919, it has become one of our most common birds, nesting in suitable places everywhere throughout southern Ontario north at least to southern Thunder Bay District and Sudbury District.

North of that, it has been found at various localities as far as 
Kapuskasing ${ }^{196}$, Moose Factory ${ }^{119}$ and York Factory ${ }^{164}$ (on Hudson bay) and it will no doubt eventually be found breeding everywhere throughout Ontario. The earliest known nesting record for this province was at Burlington, in Halton County, in $1922^{162}$, according to Isaac Balmer.

Our form is vulgaris vulgaris.

Algoma District, Amyot-Four young, in R.O.M.Z., were taken from nest by C. E. Hope on June 23, 1936.

Carleton County, Ellwood-Set of five eggs on exhibition in N.M.C. was taken on June 6,1931 , by C. E. Johnson.

Essex County, Pelee island-Flying young were seen by us on June 5, 1933.

Frontenac County, Kingston-Set of seven eggs in R.O.M.Z. was taken on May 9,1926 , by E. Beaupre.

Northumberland County, Brighton-Nest with four eggs was found on July 2, 1935, by J. L. Baillie.

Ontario County, Glen Major-Set of six eggs was found on May 19, 1935, by R. V. Lindsay and J. L. Baillie and on the same day a nest with four young was found.

Sudbury District, Chapleau-Set of two eggs was found on June 16, 1937, by J. L. Baillie.

Thunder Bay District, Rossport-Set of four eggs in R.O.M.Z. was taken on June 4, 1936, by C. E. Hope.

Victoria County, Woodville-Nest was found in 1928 by F. Starr, and a nest with seven eggs by P. Harrington on May 8, 1932.

York County, Toronto-Nest with three eggs was found at Grenadier pond on April 21, 1929, by S. L. Thompson, N. Smith and J. L. Baillie. At Humber river, R. A. Smith found a nest with five young on May 26, 1935.

\section{YELLOW-THROATED VIREO VIREO FLAVIFRONS}

The Yellow-throated Vireo is an uncommon summer resident of the extreme southern parts of Ontario, breeding north and east to Peterboro and Carleton Counties ${ }^{12},{ }^{23}$. It has been observed north to Grey County (one seen at Redwing on May 31, 1931 by R. V. Lindsay and F. H. Emery), Muskoka District (one taken at Beaumaris ${ }^{39}$ ), Parry Sound District (one seen in August, 1903 in Hardy or Patterson townships by E. H. Eaton) and Lake Nipissing (one seen at North Bay on June 3, 1924 by W. E. Ricker). Its summer occurrence in the Lake of the Woods region is attested by L. Paterson, who has observed it at Kenora on July 20, 1932. Also, there appears to be a record ${ }^{92}$ for Sault Ste. Marie, in southern Algoma District.

Brant County, near Glen Morris-Nest, in R.O.M.Z. was occupied in June, 1936 , according to W. R. Watson.

Frontenac County, Kingston-Adult was seen carrying food on June 25, 1925, by E. Beaupre. 
Halton County, Palermo-Nest with young was found about July 1, 1914, by T. F. Mcllwraith.

Kent County, Fargo-Set of four eggs, taken on June 5, 1900, is in collection of W. E. Saunders.

Norfolk County, Simcoe-Nests in the town park, according to J. W. Crow.

Peterborough County, five miles south of Peterborough-Pair was collected from nest on May 24, 1934, by G. H. Richardson.

Waterloo County, Galt-Nest was found in 1934, by G. W. Knechtel.

Wellington County, Elora-Two eggs, in R.O.M.Z., were taken on June 28, 1898 , by J. D. Jacob.

Wentworth County, Hamilton-Set of four eggs and nest were taken on May 24, 1930, by R. V. Lindsay. The nest is in R.O.M.Z.

\section{SOLITARY VIREO VIREO SOLITARIUS}

This Vireo is a rather uncommon summer inhabitant of central Ontario, from Muskoka District and Algonquin Park ${ }^{12}$, to the transcontinental line of the Canadian National Railway. It probably breeds wherever it occurs in summer, although the only definite nesting records are from Port Arthur, Amyot, Chapleau and Algonquin Park. There is at least one summer occurrence for the Lake Erie shore (one seen at Fisher's Glen, Norfolk County, on July 12, 1927, by R. V. Lindsay) and a nest with four eggs ${ }^{207}$ was found in 1931 in Ashtabula County, Ohio, on the south shore of Lake Erie, in addition to which there are nesting records for St. Lawrence County, N.Y. ${ }^{211}$, adjacent to Ontario.

This is the Blue-headed Vireo of most authors, our form being solitarius solitarius.

Algoma District, Amyot-Young bird, just out of the nest, was secured on July 4, 1936, by C. E. Hope. It is now in R.O.M.Z.

Muskoka District, Port Sydney-Breeds rarely, according to A. Kay.

Nipissing District, Biggar lake, Algonquin Park-Adult was seen with young on July 25, 1933, by D. A. MacLulich.

Sudbury District, Chapleau-Nest with four eggs was taken on June 7, 1937, by P. Harrington.

Thunder Bay District, Port Arthur-Nest with eggs was found in June, 1934, and a nest with incubated eggs on June 18, 1936, by L. S. Dear.

\section{RED-EYED VIREO VIREO OLIVACEUS}

This is the most common of the vireos occurring in Ontario, breeding everywhere from the southern border north to Lake of the Woods ${ }^{29}$, Kapuskasing and Lake Abitibi ${ }^{8},{ }^{31}$.

North of this it is very common on the Mattagami ${ }^{8}$ and Moose rivers and probably breeds north at least to the southern end of James bay. 
Cochrane District, Idington township, near Kapuskasing-Nest taken in August, 1927 , by C. L. W. Bailey is in R.O.M.Z. The two nestlings vacated the nest about August 1.

Frontenac County, Kingston-Set of four eggs in R.O.M.Z. was taken on June 10,1903 , by E. Beaupre.

Kenora District-Nested abundantly at Ontario side of Indian bay, Lake of the Woods, in 1920, according to letter from W. Rowan, and T. F. Mcllwraith saw adult feeding large young bird at Hudson on September 4, 1931.

Lambton County, Forest-New nest was found on June 4, 1935, by C. E. Hope.

Muskoka District-Nest with four eggs was found on June 13, 1923, by A. W. Needler at Robinsdale; at Torrance J. M. Speirs saw a nest with three young on July $27,1937$.

Nipissing District, North Bay-On June 18, 1904, a nest with four eggs was found by S. L. Thompson.

Parry Sound District, Frank's bay, Lake Nipissing-A nest with four eggs was found on June 14, 1933, by C. H. D. Clarke.

Simcoe County-Set of three eggs was found on June 10, 1919, by P. Harrington at Wasaga beach, and nest with three eggs in R.O.M.Z. was taken by H. B. Haugh on Little lake on July 17, 1918. At DeGrassi Point one was seen feeding a young Cowbird on July 17, 1936, by E. M. Walker and E.R. Hunter.

Thunder Bay District, Port Arthur-Set of three eggs was taken on July 1, 1924, by L. S. Dear.

York County, Toronto-A set of four eggs was taken at Humber river on May 31,1920 , by W. P. Young; a nest (vireo sitting) with six Cowbird's eggs, was found on June 24, 1921, by F. Starr. A nest with one egg in R.O.M.Z. was taken at Islington on July 15, 1895, by Joseph Parke.

\section{PHILADELPHIA VIREO VIREO PHILADELPHICUS}

The nest of this vireo has not been found in Ontario. At various localities and probably generally from the northern part of Lennox and Addington County to Moose Factory ${ }^{21}$ and west to Lac Seul, Kenora District (specimens in N.M.C. taken in the summer of 1919) it occurs more or less commonly in summer, breeding without doubt wherever it takes up its summer residence.

There is a paucity of actual breeding data but summer occurrences are rather numerous and among these are records from Muskoka District ${ }^{41}$ and Kapuskasing (July, 1919, specimens in N.M.C.). Other than those given below, the only nesting record for the province, of which we are aware, is from Lake Nipigon ${ }^{19}$, where it was observed carrying nesting material in the summer of 1924 .

Lennox and Addington County, Buckshot lake-Brood of young was seen with parents in late July, 1932, by C. H. D. Clarke.

Sudbury District, Bigwood-One was seen feeding a young Cowbird on July 18, 1937 , by C. E. Hope, who also secured a young vireo of this species, accompanied by its parent, on July 27, 1937. All are in R.O.M.Z. 


\section{WARBLING VIREO VIREO GILVUS}

The Warbling Vireo is a well-distributed and not uncommon breeding summer resident of southern Ontario, especially in urban centres, from the southern border north ${ }^{39},{ }^{41}$ at least to Parry Sound District, north Frontenac (ounty and Ottawa ${ }^{113}$ and at Port Arthur. It breeds also in the Lake of the Woods District ${ }^{29}$ of Manitoba, but not, so far as we are aware, on the Ontario side, and its occasional occurrence on Lake Nipissing at North Bay is attested by W. E. Ricker.

Our form is the Eastern Warbling Vireo, gilvus gilvus.

Durham County, Nestleton-Occupied nest was found by L. T. Owens in July, 1936.

Elgin County, Aylmer-Set of three eggs in R.O.M.Z. was taken by R. T. Anderson.

Frontenac County, Arden-Nest with two young was found on June 19, 1933, by R. V. Lindsay.

Huron County, Brussels-Nest with eggs was found in June, 1923, by C. H. D. Clarke.

Kent County, Fargo-A set of four eggs in collection of W. E. Saunders was taken on June 14, 1901.

Leeds County, Athens-A nest with young was found in 1927, according to M. W. Curtis.

Northumberland County, Warkworth-Nest was found on June 1, 1932, by O. E. Kelly.

Simcoe County, Cookstown-Nest has been observed by M. W. Curtis.

Thunder Bay District, Port Arthur-Breeds commonly, according to L. S. Dear.

York County, Toronto-Nest with two eggs was found on June 9, 1936, by H. H. Southam (nest in R.O.M.Z.); adults were seen feeding young on July 22, 1927 , by R. J. Rutter.

\section{BLACK AND WHITE WARBLER MNIOTILTA VARIA}

This warbler, one of twenty-nine species known to nest within the borders of Ontario, is a common summer resident of the province north to Lake of the Woods ${ }^{29},{ }^{176}$ and the southern end of James bay ${ }^{12}$. It was noted also at Oasis lake on the Manitoba-Ontario boundary between Lat. $53^{\circ}-54^{\circ} \mathrm{N}$. during the summer of 1930 by D. R. Derry.

It nests north from the southern border ${ }^{22}$ to the transcontinental line of the Canadian National Railway ${ }^{31}$ and probably throughout its range.

Carleton County, Ottawa-W. E. Saunders took a set of five eggs in June, in the eighteen-eighties.

Frontenac County, Bedford township-Adults were seen with young on July 27,1923 , by E. Beaupre.

Kenora District-L. Paterson saw young being fed by parents at Kenora on July 18,1932 , according to B. W. Cartwright, and W. Rowan informs us ${ }^{29}, 190$ that it was a common nesting species in 1920 on the Ontario side of Indian bay, Lake of the Woods. 
Muskoka District, Lake Joseph-Nest with five eggs was found by R. D. Ussher on June $15,1929$.

Nipissing District-At Eau Claire, young were seen June 29-July 2, 1935, by T. M. Shortt and one was seen feeding young at Frank's bay, Lake Nipissing, on June 24,1933 , by C. H. D. Clarke.

Norfolk County, Fisher's Glen-Found breeding in 1931 by H. Fulcher.

Simcoe County-H. P. Bingham took a set of four eggs on June 10, 1923, at Barrie, and at Wasaga beach O. E. Devitt found a nest on June 24, 1934, containing three eggs plus egg of Cowbird.

Sudbury District, Biscotasing-Juvenile, just out of nest, was observed by C. E. Hope on June 30, 1937.

Victoria County-Nest with three eggs was found on May 25, 1930, by F. Starr, who also saw a nest with young on July 21,1925 , and a nest with four eggs on June 29, 1930, all at Bobcaygeon. At Woodville, F. Starr discovered a nest with four eggs on July 12, 1930.

York County-One was seen feeding a young Cowbird at Mount Dennis on July 1, 1928, by C. E. Hope and R. V. Lindsay, and at King R. D. Ussher saw young attended by parents on July 15, 1934.

\section{PROTHONOTARY WARBLER PROTONOTARIA CITREA}

The only known nesting place of this southern warbler in Ontario is Rondeau park ${ }^{201}$ on Lake Erie. Three adults, however, were seen on June 28, 1936, at Big creek, near Port Rowan, by G. W. North and G. W. Knechtel. Aside from Rondeau park, it occurs only as a very rare visitor south and west of York County ${ }^{107}$. It is known to nest also near Medina, N.Y. ${ }^{210}$, not far east of the Niagara river and consequently just beyond our limits.

Kent County, Rondeau Park-Mrs. J. H. Smith found a brood of four young with their parents in 1929 and on June 14, 1931, four nests were found by $E$. Davis, F. H. Emery and E. M. S. Dale. (Dale's and Davis' contained four young and those found by Emery held three eggs and a young Cowbird and one egg and three young plus a young Cowbird). In June, 1933, upwards of one hundred pairs were present in the park and we located at least six nests, one of which was empty. The contents of the others were as follows: one on the 2nd with seven Cowbird's eggs, one on the 7th with six eggs, one on the 9th with five eggs, one on the 10th with three eggs in addition to seven Cowbird's eggs, and one on the 12th with four eggs. F. H. Emery and O. E. Devitt found a nest with six eggs and a nest with well-developed young in 1934 .

\section{GOLDEN-WINGED WARBLER VERMIVORA CHRYSOPTERA}

This southern warbler occurs in summer not uncommonly in certain places in the south-western peninsula of Ontario, south of Middlesex and Simcoe Counties (one seen at Collingwood on June 11, 1929, by P. Harrington and F. Starr) and west of Durham County, where J. H. Jennings saw one (at Bowmanville) on May 10, 1934. 
It is known to breed only in Middlesex ${ }^{22}$ and Norfolk Counties.

Norfolk County, Turkey Point-Nest (nearly completed) taken on May 21, 1933 by R. J. Rutter, is in R.O.M.Z.

\section{TENNESSEE WARBLER VERMIVORA PEREGRINA}

In summer this warbler occupies that section of the province north of Lat. $47^{\circ} \mathrm{N} .{ }^{82}$.

It is fairly common, breeding throughout its range ${ }^{9}$, but the only actual nesting records, other than those given below, are from Pic (seen with young between July 11 and August 6, 1848, by J. E. Cabot ${ }^{82}$ and Fairloch (nest ${ }^{19}$ with four eggrs in R.O.M.Z. taken on July 21, 1924, by J. L. Baillie) both in Thunder Bay District, and Michipicoten, Algoma District ${ }^{220}$ (nest with two eggs found by George Barnston prior to 1874). One was noted ${ }^{12}$ on July 5, 1904, at East point, James bay, Ontario, by Spreadborough, and P. A. Taverner and C. E. Johnson found it not uncommonly at Kapuskasing, June 27 - July 7, 1919.

Kenora District, Lac Seul-Young (just out of the nest) taken on July 10, 1919 by D. Blakely, is in N.M.C.

Sudbury District, Biscotasing-Young, in R.O.M.Z., was secured by C. E. Hope on July $6,1937$.

Thunder Bay District, Whitefish lake-Nest with four eggs was taken on June 8,1935 by L. S. Dear; the nest is in R.O.M.Z.

\section{NASHVILLE WARBLER VERMIVORA RUFICAPILLA}

The Nashville Warbler is a common summer resident of Ontario, north to the transcontinental line of the Canadian National Railway ${ }^{31}$, breeding throughout its range ${ }^{16},{ }^{19},{ }^{22}$ west to southern Kenora District.

Our form is ruficapilla ruficapilla.

Durham County, Hampton-Set of three eggs, plus egg of Cowbird, was taken on May 24, 1930, by A. E. Allin.

Haliburton District, Hawk lake-Set of four eggs was taken by E. Dixon.

Hastings County, northern part-Set of five eggs was taken on May 30, 1928, by E. Beaupre.

Kenora District, Wabigoon-Adult was seen feeding young, out of nest, on July 1 , 1937, by T. M. Shortt.

Muskoka District-Near Fox point, Lake of Bays, families of adults with flying young were seen by T. F. Mcllwraith in early August, 1932. Sets of three and four eggs in R.O.M.Z. were taken by A. Kay at Port Sydney on June 11,1900 , and June 15,1891 , respectively.

Parry Sound District-At Katrine it breeds, according to R. J. Rutter, and it was seen feeding young at Frank's bay, Lake Nipissing, on June 25, 1933, by C. H. D. Clarke.

Renfrew County, Petawawa-Nest (collected) on June 26, 1935, by C. E. Hope, contained three young birds. All are in R.O.M.Z. 
Simcoe County, Orr lake-Set of three eggs plus two Cowbird's eggs were found by us on June 7,1929 .

Sudbury District, Chapleau-Nest with five eggs was found on June 14, 1937, by $\mathrm{P}$. Harrington.

Thunder Bay District, Whitefish lake-A nest (in R.O.M.Z.) with five eggs was collected on June 10,1935, by P. Harrington.

\section{PARULA WARBLER COMPSOTHLYPIS AMERICANA}

The nest of this species has not been reported from this province. Summer records, however, indicate that it is found locally throughout most of the eastern half of the province from Lake $\mathrm{Erie}^{27}$ and north Hastings County (male in R.O.M.Z. taken by C. E. Hope on June 22, 1935) north at least to Lake Abitibi ${ }^{31}$ and west probably to the west end of Lake Superior (one noted by us in June, 1935, at Whitefish lake).

The only actual breeding record, of which we are aware, is recorded below from Algonquin park, but a set of four eggs in the British Museum ${ }^{202}$, supposed to be of this species, was taken at Buffalo, N.Y., on May 27.

Our form is the northern race, americana pusilla.

Muskoka District, Port Sydney-Breeds, according to A. Kay.

Nipissing District, Brule lake, Algonquin Park-Adults were seen feeding young on July 9,1934 , by C. H. D. Clarke.

\section{YELLOW WARBLER DENDROICA AESTIVA}

This is a common and familiar warbler of Ontario, nesting north from the southern border to Hudson's bay ${ }^{9},{ }^{99}$ and west to Lake of the Woods, much more commonly in the southern half of the province. ${ }^{23}$

Ontario Yellow Warblers are considered to be aestiva aestiva.

Cochrane District, Banks lake, Fenton township, near Kapuskasing-Pair was seen feeding young on July 12,1925 , by R. D. Ussher.

Essex County-Set of five eggs was found by us at Pelee island on June 5, 1933. At Point Pelee, W. E. Saunders collected a set of five eggs on June 2, 1913.

Kenora District, Kenora-L. Paterson found a nest with three eggs on June 7, 1931, according to B. W. Cartwright.

Lincoln County, St. Catharines-Nest with three eggs plus Cowbird's egg was found on May 27, 1936, by G. J. Clout.

Muskoka District, Robinsdale-A nest photographed by A. W. Needler with four eggs on June 9, 1923, contained four young on the $22 \mathrm{nd}$.

Nipissing District-Nest was seen nearing completion on May 31, 1925, by J. L. Baillie at North Bay, and a nest with four eggs was seen on June 2, 1933, by C. H. D. Clarke. A nest was taken at island 758 , Temagami, by A. F. Coventry on July 9,1935 , the date on which the young left it.

Ontario County, Beaverton-A set of four eggs was taken on July 5, 1909, by J. A. Edwards. 
Simcoe County-Nest in R.O.M.Z. with three imbedded Cowbird's eggs in addition to four warbler's eggs was found on June 11, 1927, by P. Harrington at Marl lake. At Barrie, H. P. Bingham took a set of five eggs on June 1, 191 ij.

Thunder Bay District-P. Harrington saw a nest with four eggs on June 8, 1935, at Whitefish lake; at Port Arthur L. S. Dear took a set of five eggs on June 21,1924 .

York County, Toronto- Nest with five eggs was found at the Humber river by C. G. Harbour on May 27, 1911; and a set of four eggs in R.O.M.Z. was taken on June 27,1891 , by J. L. Jackson. R. A. Smith found a nest with two young at Ashbridge's bay on June 23, 1935. Set of two eggs in R.O.M.Z. was found at Centre island on June 30,1906 , by L. B. Brown.

\section{MAGNOLIA WARBLER DENDROICA MAGNOLIA}

In the coniferous forests of Ontario, north from about Lat. $44^{\circ}$ to the Albany river ${ }^{12},{ }^{21}$, this warbler is a fairly common summer resident, in many places ${ }^{19}$ being the most abundant of the family.

It breeds from southern Georgian bay and Frontenac County ${ }^{12}$ to the transcontinental line of the Canadian National Railway ${ }^{31}$, westward to Thunder Bay District and probably to Lake of the Woods ${ }^{176}$. Instances of its breeding along our southern border may be expected, since it is known to nest ${ }^{211}$ in St. Lawrence County, New York, adjacent to the St. Lawrence river.

Algoma District, Mississagi Forest reserve-Nest with five eggs was found by R. D. Ussher on June 12, 1923.

Cochrane District, Kapuskasing-Flightless young was collected in the summer of 1919 , according to P. A. Taverner.

Frontenac County, Sharbot lake - Nest containing two eggs as well as three Cowbird's eggs was found on May 31, 1922, by E. Beaupre.

Manitoulin District, McGregor bay-Set of four eggs (two in R.O.M.Z.) was taken on June 10,1925 , by B. A. Bensley.

Muskoka District-Set of four eggs (one in R.O.M.Z.) was taken in Stephenson township on June 5, 1902, by A. Kay. T. F. Mcllwraith saw adults feeding flying young in early August, 1932, near Fox point, Lake of Bays.

Nipissing District-Nest with four young (in R.O.M.Z.) was taken on June 30, 1935, by C. E. Hope at Eau Claire. At Wilson lake, Temagami, O. E. Devitt found young being fed by parents on August 6, 1934 .

Parry Sound District, Frank's bay, Lake Nipissing-Nest in R.O.M.Z. was taken on June 25, 1933, by D. A. MacLulich. It contained five eggs on the 9 th.

Simcoe County, Wasaga beach--Set of four eggs was taken on June 12, 1923, by F. Starr.

Sudbury District-Nest with three eggs found at Chapleau on June 7, 1937, by C. E. Hope is in R.O.M.Z.; at Biscotasing he also found a nest with four eggs on June 23, 1937.

Thunder Bay District, Port Arthur-Set of four eggs was taken on June 29, 1922, by L. S. Dear. 


\section{CAPE MAY WARBLER DENDROICA TIGRINA}

The Cape May Warbler has been found to be a very rare summer resident of Ontario between Bruce County and James bay ${ }^{21}$ and west to Lac Seul. In the Bruce peninsula it is fairly common in certain places, e.g. at Dorcas bay, and it breeds fairly commonly also in Sudbury District.

The only breeding records of which we are aware are recorded below.

Bruce County, Dorcas bay-Nest with six eggs was taken on June 12, 1934, by P. Harrington and an agitated female was taken on July 15, 1933, (in R.O.M.Z.) by J. L. Baillie.

Kenora District, Lac Seul-Juveniles taken on June 28, and August 9, 1919, by D. Blakely are in N.M.C.

Sudbury District, Biscotasing-Small young, in R.O.M.Z., was collected on July 1, 1937, by C. E. Hope.

\section{BLACK-THROATED BLUE WARBLER DENDROICA CAERULESCENS}

The Black-throated Blue Warbler occurs sparingly in the deciduous woods of Ontario north to Lake of the Woods ${ }^{29}$ (one was seen at Minaki on July 22, 1930, by A. G. Lawrence and male in N.M.C. was taken by D. Blakely on June 27, 1919, at Lac Seul), southern Thunder Bay District (rare summer resident, according to L. S. Dear) and Kapuskasing.

It undoubtedly nests throughout its range ${ }^{12}$ as it has been found breeding north and west from Leeds and Wellington Counties at least to northern Algoma District ${ }^{109}$ and southern Cochrane District, and west to Cook County ${ }^{176}$, Minnesota, adjacent to Lake Superior, Ontario.

Cochrane District, near Kapuskasing-Nest with three eggs was found on July 8,1925 , by R. D. Ussher at Bank's lake, Fenton township.

Frontenac County, Sharbot lake-Nest and four eggs in R.O.M.Z. were taken by C. K. Clarke on May 28, 1903.

Grey County, Durham-Set of four eggs, plus Cowbird's egg, was taken on June 22, 1909, by W. E. Saunders.

Haliburton District, Maple lake-Nest and four eggs in R.O.M.Z. were collected on July 3,1935 , by C. E. Hope.

Muskoka District, Lake Joseph-Adult was seen feeding young on July 20, 1929, by R. D. Ussher.

Nipissing District, Little Nipissing river, Algonquin Park-Nest in R.O.M.Z. contained four eggs when found on June 25, 1930, by D. A. MacLulich.

Parry Sound District, Emsdale-Nest with two eggs in R.O.M.Z. was taken in June, 1894, by J. H. Fleming.

Simcoe County, Barrie-Set of four eggs was taken on July 4, 1918, by H. P. Bingham.

Sudbury District, Chapleau-On June 17, 1937, P. Harrington found a nest containing four eggs. 


\section{MYRTIE WARBLER DENDROICA CORONATA}

The Myrtle Warbler is a common summer resident of Ontario, breeding from Wellington County ${ }^{40}$, northern York County and Frontenac county to the transcontinental line of the C.N.R. ${ }^{19}$, ${ }^{\text {s1 }}$ (and probably to James lay $\left.y^{9},{ }^{12}\right)$, west to Lake of the lloods. Several were identified in July, 1930, hy L). R. Derry along the Manitoba-Ontario boundary between Lat. $53^{\circ}-54^{\circ} \mathrm{N}$.

It reaches its centre of abundance between Georgian bay and ()ttawa, in many places being the most common breeding warbler.

Algoma District, Bachawana bay-Young were seen being fed by parents on July 12,1935 , by C. H. D. Clarke.

Cochrane District-At Bank's lake, Fenton township, near Kapuskasing, an adult was watched feeding young on July 14,1925 , by R. D. Ussher, and E. Dixon has eggs taken by A. V. Dukes at Lake Abitibi.

Frontenac County, Gull lake, near Sharbot lake - On June 10, 1902, E. Beaupre found a nest with young birds a few days old.

Kenora District, Kenora-Pair was seen building nest on May 23, 1931, by L. Paterson, according to B. W. Cartwright.

Manitoulin District, McGregor bay-Set of five eggs taken on June 14, 1925, by B. A. Bensley is in R.O.M.Z.

Parry Sound District-Young bird was seen awing on July 13, 1936, by J. L. Baillie, at Pickerel lake, east of Burk's Falls. At Sans Souci, P. Harrington found a nest with one Cowbird's egg on May 23, 1921. J. M. Speirs found a nest with young at Sundridge in July, 1931.

Renfrew County, Petawawa-Set of four eggs was found on June 19, 1916 by P. Harrington, who also found a nest with three eggs on May 26, 1916.

Simcoe County-Almost fifty occupied nests have been found at Wasaga beach by $\mathrm{P}$. Harrington between 1913 and 1937 , one of which was a nest containing four eggs found on May 28,1913. On July 17, 1914, he found a nest with two eggs plus a Cowbird's egg. At DeGrassi Point, E. R. Hunter saw one feeding a young Cowbird on July 17, 1936.

Thunder Bay District-At Port Arthur, L. S. Dear found a nest with three eggs plus egg of Cowbird on June 11, 1929. At Rossport P. Harrington secured a nest with four eggs on June 7, 1936.

York County, Island grove - One was seen feeding young Cowbird in 1935, by W. W. H. Gunn.

\section{BLACK-THROATED GREEN WARBLER DENDROICA IIRENS}

This warbler is a common summer resident of Ontario from the southern border ${ }^{27}$ north ${ }^{\mathbf{1 2 7}}$ to Lac Seul and Noose Factory ${ }^{12}$. It breeds north to the Transcontinental railway ${ }^{19}$ and likely throughout its range.

The Ontario form is virens virens.

Durham County, Bowmanville-Found breeding in 1928 by S. L. Thompson.

Frontenac County, Murvale- Set of four eggs in R.O.M.Z. was taken on June 12, 1905, by E. Beaupre. 
Haliburton District, Maple lake-Young birds were seen on July 5, 1935, by T. M. Shortt.

Muskoka District, Lake Joseph-R. D. Ussher saw parent feeding young on July 3, 1922.

Parry Sound District-Family of adults with young was seen at Gordon bay on August 11, 1932, by J. L. Baillie and J. M. Speirs saw young at Sundridge in July, 1931.

Simcoe County - Set of three eggs, plus Cowbird's egg, was taken by us at Orr lake on June 5,1928 . On July 5,1915 , P. Harrington found young just out of the nest at Wasaga beach.

Sudbury District, Bigwood-Young collected by C. E. Hope on July 14, 1937, are in R.O.M.Z.

Victoria County, Woodville-Young (just out) were seen at nest on June 22, 1930, by F. Starr. The nest is in R.O.M.Z.

York County-Has been found breeding by C. W. Nash at Toronto, and at Nancy lake members of the T.O.F.G. found three young with parents on July 18 , 1937.

\section{CERULEAN WARBLER DENDROICA CERULEA}

The Cerulean Warbler breeds in but six of the extreme southern counties of Ontario (Kent ${ }^{201}$, Middlesex ${ }^{22}$, Wentworth ${ }^{5}$, Lambton, Lincoln and Welland ${ }^{83}$ ), rather commonly in certain localities.

That its breeding range is more extended than the actual nesting data indicate is suggested by its occurrence rarely north ${ }^{60}$ and east to Ottawa $^{23}$, and there is an indefinite nesting record for Leeds County ${ }^{197}$.

Kent County-Common at Rondeau in early June, 1933, and a female was seen by us on its inaccessible nest on the 13th. Two sets of four eggs were taken at Fargo on June 5, 1900, by W. E. Saunders, who also has a set of three eggs taken at Coatsworth on June 8, 1909.

Lambton County, Thedford-Female parent and empty new nest in R.O.M.Z. were collected by C. E. Hope on June 4, 1935.

Lincoln County, Warner-Female was seen with four young on July 15, 1936, by W. E. Hurlburt and R. E. Wright.

Middlesex County, Byron-Nest with four newly-hatched young was found on June 14, 1928, by G. W. Knechtel.

\section{BLACKBURNIAN WARBLER DENDROICA FUSCA}

This warbler is a fairly common summer resident of the whole of the province north from Lake Erie ${ }^{27}{ }^{221}$, and Ottawa ${ }^{23}$ to Hudson bay ${ }^{21}$.

Breeding records are at hand for many localities between our southern border and Lac Seul and Temagami and it probably breeds in suitable places throughout Ontario.

Algoma District, Bachawana bay-Adults were seen feeding young on July 16,1935 , by C. H. D. Clarke.

Kenora District, Lac Seul-Young collected in the summer of 1919 by P. A. Taverner are in N.M.C. 
Muskoka District - Three young birds, being fed by parents, were seen on July 2 , 1922, by R. D. Ussher at Lake Joseph. At Torrance, J. M. Speirs saw a nest with two young on July 26, 1937.

Nipissing District, Bear island, Lake Temagami-Brood of young was seen on July 24, 1928, by A. F. Coventry.

Parry Sound District-Family of adults and young was seen at Gordon bay on August 11, 1932, by J. L. Baillie, and young were seen at Sundridge in July, 1931, by J. M. Speirs.

Renfrew County, Petawawa-Breeds, according to P. Harrington.

Simcoe County, Barrie-A nest with two eggs was found on June 9, 1923, by H. P. Bingham.

Sudbury District, Biscotasing-Young, in R.O.M.Z., was collected by C. E. Hope on July $3,1937$.

Thunder Bay District, Port Arthur-Set of four eggs was taken with nest (which is in R.O.M.Z.) on June 17, 1934, by L. S. Dear.

Victoria County, Bobcaygeon-Found nesting in June, 1933, by F. Starr.

\section{CHESTNUT-SIDED WARBLER DENDROICA PENSYlvanica}

The Chestnut-sided Warbler is a fairly common summer resident of Ontario north to Lat. $55^{\circ} \mathrm{N}$. on the Manitoba-Ontario boundary ${ }^{19},{ }^{190}$, northern Algoma District ${ }^{12}$ and Lake $\mathrm{Abitibi}^{31}$, nesting throughout its range ${ }^{12} \cdot{ }^{22}$.

Frontenac County, Sharbot lake-Set of four eggs was taken on June 6, 1914, by C. J. Young.

Haliburton District, Dysart township-E. W. Calvert found nests with three eggs on June 18 and July 19, 1936.

Hastings County, Madoc--Set of three eggs in R.O.M.Z. was taken by C. J. Young on June 15, 1905.

Kenora District-At Kenora, adults were seen feeding young on July 27, 1931, by L. Paterson and an adult was seen feeding young on August 7, 1936, at Ney lake (Lat. $54-55^{\circ} \mathrm{N}$. on Manitoba-Ontario boundary) by J. Satterly.

Parry Sound District, Frank's bay, Lake Nipissing-Nest with four eggs in R.O.M.Z. was taken by C. H. D. Clarke on June 7, 1933.

Renfrew County, Combermere-Nest with one egg, in R.O.M.Z. was collected on June 25, 1935, by T. M. Shortt.

Simcoe County-Set of two eggs and Cowbird egg were taken on June 23, 1921, by P. Harrington at Wasaga beach. At Barrie, H. P. Bingham found a nest with three eggs on June 18, 1916.

Thunder Bay District, Port Arthur-Set of four eggs was taken on June 29, 1924 , by L. S. Dear.

Wellington County, EImira-Nest with two eggs was found on June 10, 1928 by G. W. Knechtel.

York County, Toronto-Nest with one egg as well as an egg of Cowbird was shown to J. L. Baillie on June 11, 1931, by C. E. Hope at Hogg's hollow. At Moore park, S. L. Thompson found young with parents on July 18, 1902. 


\section{BAY-BREASTED WARBLER DENDROICA CASTANEA}

The nest of this warbler has not been reported from Ontario. It is, however, not uncommon as a breeding summer inhabitant of certain localities between the northern part of the Bruce peninsula and the transcontinental line of the Canadian National Railway ${ }^{31}$ (small young seen at Lake Abitibi in 1925).

The numerous records of its summer occurrence in Cochrane District (one in R.O.M.Z. taken at Moose Factory by S. Waller on June 6, 1928), in Kenora District (male seen on July 11, 1930, by D. R. Derry at Gorman creek between Lat. $53^{\circ}$ and $54^{\circ} \mathrm{N}$. on the Manitoba boundary), in Temiskaming District (breeding pair secured ${ }^{198}$ at Annina on July 11, 1906), Nipissing District (male seen on July 1, 1935 at Eau Claire by T. M. Shortt and noted on July 12, 1931, by G. H. Richardson in Algonquin park), in Parry Sound District (seen in July, 1931, at Sundridge by J. M. Speirs), in Victoria County (seen in July, 1932, by J. M. Speirs at Norland), in Thunder Bay District (fairly common in summer of 1924 at Lake Nipigon, according to R.O.M.Z. field party) and in Algoma District (fairly common in July, 1936 according to R.O.M.Z. field party) indicate that it is much more common and widespread as a summer resident than is supposed.

Bruce County, Dorcas bay-Fairly common in early June, 1934, and adults were observed carrying nesting materials on the 5 th by $P$. Harrington and F. Starr.

Cochrane District, Bank's lake, Fenton township, near Kapuskasing-Several were seen feeding young on small islands in lake on July 12,1925 , by R. D. Ussher.

Sudbury District, Biscotasing-Young, in R.O.M.Z., were collected by C. E. Hope on July 6, 1937.

\section{PINE WARBLER DENDROICA PINUS}

The Pine Warbler is a summer resident of southern Ontario, breeding in small numbers and locally from the southern border ${ }^{27},{ }^{212},{ }^{221}$ north to northern Algoma District ${ }^{109}$ and Renfrew County.

Its presence in summer in the vicinity of Lake of the Woods ${ }^{29}$ (Manitoba) would indicate the possibility of its breeding on the Ontario side of the lake.

Our form is considered to be the typical one, pinus pinus.

Halton County, 4 miles west of Boyne-On May 17, 1936, a female was seen carrying nesting materials by P. Harrington, A. E. Allin and J. L. Baillie.

Norfolk County, Simcoe-Nests in the town park, according to J. W. Crow.

Parry Sound District, Frank's bay, Lake Nipissing-Adult was seen carrying food on June 26, 1933, by C. H. D. Clarke. 
Renfrew County, Petawawa-Nest with one egg was found on June 7, 1916, by P. Harrington.

Simcoe County, Wasaga beach-Fairly common in the breeding season; a set of three eggs plus a Cowbird's egg was taken by P. Harrington on June 16, 1922.

\section{PRAIRIE WARBLER DENDROICA DISCOLOR}

This southern warbler occurs as a well-distributed but scarce and local summer resident of southern Ontario from places on Iake Erie (female seen at St. Williams, Norfolk County on July 23, 1934, by G. II. North), north to Parry Sound District and Renfrew County ${ }^{86}$. A single occurrence at Frank's bay, Lake Nipissing, on June 24, 1933, is reported by $\mathrm{C}$. $\mathrm{H}$. D. Clarke.

It is known to breed fairly commonly about the shores of southern Georgian bay ${ }^{87},{ }^{102}$ and southern Lake Huron but not elsewhere in the province.

The form breeding in Ontario is said to be discolor discolor.

Lambton County-Nest in R.O.M.Z. was taken near Grand Bend by L. L. Snyder on June 6, 1935. Young were seen out of the nest about July 3, 1934, at Beach o'Pines (nine miles south of Grand Bend) by K. Reynolds.

Muskoka District-Young bird (one of three seen) being fed by parents was collected at Honey Harbour by R. J. Rutter on July 12, 1934. At Go Home bay, J. B. Armstrong saw parents feeding young on July 16,1934 , and there is an immature from the same place (in R.O.M.Z.) taken on August 1, 1904, by D. Black.

Simcoe County, Wasaga beach-Nest with four young was found on June 24, 1934, by O. E. Devitt.

\section{PALM WARBLER DENDROICA PALMARUM}

The only known nesting stations of the Palm Warbler in Ontario are, strangely enough, from opposite ends of the province, on an island in Lake of the Woods ${ }^{29}$ (probably in Ontario, according to letter from W. Rowan) and at Mer Bleue, (Carleton County ${ }^{12},{ }^{23}$ near the Ottawa river).

That it may breed rarely in various parts of northern Ontario, however, is indicated by its occurrence in summer (July, 1860) at the south end of James bay ${ }^{12}$, at Churchill (Manitoba) ${ }^{21}$, in Algoma District ${ }^{17}$, breeding in St. Louis and Cook Counties, Minnesota ${ }^{176}$ (adjacent to Ontario) and at Sault Ste. Marie ${ }^{82}$ (seen during the summer of 1848 by J. E. Cabot).

Our form is probably palmarum palmarum.

Carleton County, Mer Bleue-Pair was seen feeding young by W. E. Saunders on May 30,1901, and on the same day Dr. Saunders took a set of four heavily incubated eggs. This is set number 3814 in his collection. 


\section{OVEN-BIRD SEIURUS AUROCAPILLUS}

The Oven-bird is a common summer resident throughout most of Ontario north to southern Kenora District and James bay ${ }^{12}$.

It likely breeds throughout this range but it is known to do so only north to the transcontinental line of the Canadian National Railway ${ }^{19}$, north of which there has been little ornithological work done. Its presence in the summer of 1920 at Indian bay, Lake of the Woods (Manitoba) ${ }^{29}$ would suggest its summer occurrence in the Lake of the Woods district of Ontario and north of this at Family lake, Lat. $52^{\circ} \mathrm{N}$. on the Manitoba side of the Manitoba-Ontario boundary a nest with five eggs was found on June 19, 1927 by R. D. Ussher.

Algoma District, Mississagi Forest reserve-Nest with five eggs was found on June 11, and nest with three or four newly hatched young on July 11, 1923, by R. D. Ussher at Kindiogami lake.

Cochrane District, near Kapuskasing - Nest with four young was found on June 27, 1925, by R. D. Ussher at Bank's lake, Fenton township.

Elgin County, Port Burwell-Set of five eggs plus egg of Cowbird was taken on June 11, 1924, by F. Starr.

Frontenac County, Kingston-Set of five eggs was taken on June 3, 1896, by E. Beaupre.

Haliburton District, Dysart township-On June 24, 1936, a nest with four eggs was found and a flying brood was seen on the same date by E. W. Calvert.

Huron County, West Wawanosh township-A set of three eggs was taken on July 21,1935 , according to R. Smyth.

Kenora District, Wabigoon-Nest with four young was found on June 21, 1937, by T. M. Shortt.

Sudbury District, Parkin township-Nest with four young was found on July 8, 1929, by D. A. MacLulich.

Thunder Bay District-Set of four eggs was collected by L. S. Dear at Port Arthur on July 6, 1926; at Whitefish lake Colonel Dear showed us a nest with three eggs on June 8, 1935.

York County-At King, R. D. Ussher found a nest with five eggs on June 16, 1935, and on August 19, 1928 at Pottageville J. L. Baillie saw an adult feeding a young bird.

\section{NORTHERN WATER-THRUSH SEIURUS NOVEBORACENSIS}

The Northern Water-Thrush is a common inhabitant of the wet woods of Ontario, breeding north to Lake of the Woods ${ }^{29}$ and James bay ${ }^{12}$ and without much doubt throughout the province ${ }^{9},{ }^{21}$.

Kenora and Thunder Bay Districts records may ${ }^{9}$ refer to noveboracensis notabilis ${ }^{19}$ but the race occupying most, if not all of the province, is noveboracensis noveboracensis.

Cochrane District, Kapuskasing-Juvenile obtained on June 23, 1919, by P. A. Taverner is in N.M.C. On June 30,1925, R. D. Ussher discovered a nest with four eggs near Kapuskasing, at Bank's lake, Fenton township. 
Durham County, Hampton-Set of five eggs was found on May 26, 1926, by A. E. Allin; and a nest with two eggs (originally three) in R.O.M.Z. was secured on June 6, 1934, by the same collector.

Kenora District-Young bird taken at Lac Seul on August 16, 1919, by D. Blakely is in N.M.C. A pair bred in 1920 on an island in the Ontario part of Indian bay, Lake of the Woods, according to letter from W. Rowan.

Muskoka District, Port Sydney-Breeds, according to A. Kay.

Parry Sound District, Pickerel lake, near Burk's Falls-Young, just out of the nest, was secured on July 16, 1936, by J. L. Baillie.

Peel County, Belfountain-Young bird was seen by J. L. Baillie on June 14, 1931.

Simcoe County-Nest with two young and two eggs as well as three young Cowbirds was found at Cranberry lake on June 5, 1929, by us. At Barrie, H. P. Bingham took a set of five eggs on May 25, 1924.

Thunder Bay District-L. S. Dear took a set of four eggs at Port Arthur on June 19, 1914, and F. Starr took a nest with five eggs at Whitefish lake on June 4, 1935 .

Victoria County, Bobcaygeon-Nest and five eggs in R.O.M.Z. were taken on May 23, 1930, by F. Starr.

York County, Pottageville-Nest with four eggs was found on May 24, 1935, by H. H. Southam.

\section{LOUISIANA WATER-THRUSH SEIURUS MOTACILLA}

This bird of the Carolinian zone reaches the lower edge of Ontario in small numbers, occurring north to Middlesex ${ }^{22}$ and east to Frontenac Counties $^{43},{ }^{152}$.

The only known nesting places in the province at present are at Rondeau Park ${ }^{201}$ and in Middlesex and Wentworth Counties, but it is known to nest also near Buffalo, N.Y., ${ }^{209}$ close to our southern border.

Elgin County, Aylmer-Set of three eggs in R.O.M.Z. was taken in 1895, by R. T. Anderson.

Kent County, Rondeau-Numerous in early June, 1933, and a nest with four eggs plus three Cowbird's eggs was secured on the 2 nd by us.

Middlesex County-According to K. Reynolds, young were seen with parents in July, 1935 and a nest with two well-grown young was found near Komoka on May 30, 1936, by W. J. Preston (notice appeared in the "Prothonotary" July, 1936.) The nest also contained a young Cowbird, according to P. Henderson. Photographs of this nest have been received from Mr. Reynolds.

Wentworth County, Webster's Falls-Nest with five young was found on June 23, 1937, by A. H. Lawrie.

\section{CONNECTICUT WARBLER OPORORNIS AGILIS}

The nest of this species has not been reported from Ontario but it has been recorded as a rare summer resident of Cochrane ${ }^{31}$, Algoma and Thunder Bay Districts ${ }^{19}$ in northern Ontario.

The only nesting evidence is from Gargantua, near Agawa, Algoma District ${ }^{17}$, where a pair was seen feeding a young bird on August 17, 1918, by M. J. Magee. 


\section{MOURNING WARBLER OPORORNIS PHILADELPHIA}

The Mourning Warbler is a fairly common summer resident of Ontario, breeding north to the Transcontinental railway (C.N.R.) ${ }^{12},{ }^{29},{ }^{31}$ and west to Lake of the Woods ${ }^{176}$.

Algoma District, Bachawana bay-Adults were seen feeding young on July 12, 1935 , by C. H. D. Clarke.

Cochrane District, Kapuskasing-A female collected during the summer of 1919 had an egg in oviduct almost ready to be laid, according to P. A. Taverner.

Frontenac County, Mountain Grove-On July 6, 1926, R. V. Lindsay saw a female carrying food.

Kenora District, Kenora-Pair was seen feeding young by L. Paterson on July 18,1932 , according to B. W. Cartwright.

Parry Sound District, Pickerel lake, near Burk's Falls-J. L. Baillie saw young attended by parents on July 28, 1936.

Simcoe County-Set of two eggs plus one egg of Cowbird was taken at Minesing on June 9, 1929, by P. Harrington, who also found four young in nest at Wasaga beach on June 12, 1922.

Sudbury District, Bigwood-Young, in R.O.M.Z., was secured on July 24, 1937, by J. L. Baillie.

Thunder Bay District, Port Arthur-Set of four eggs was secured on June 19, 1927 , set of four eggs on July 1, 1923, and set of three eggs on June 22, 1924, by L. S. Dear.

Victoria County, Bobcaygeon-Set of five eggs was taken on June 8,1931 , by F. Starr.

York County-Set of three eggs plus egg of Cowbird was taken on June 15, 1930, by C. E. Hope at Mount Dennis. On July 30, 1895, J. H. Samuel found adults attending young at Lambton.

\section{MARYLAND YELLOW-THROAT GEOTHLYPIS TRICHAS}

The Yellow-Throat is a common breeding summer resident of Ontario north to southern Kenora and northern Sudbury Districts ${ }^{16}$. That it nests sparingly in northern Ontario beyond these points is indicated by its occurrence in summer at Churchill (Manitoba) ${ }^{9}$ and near Moose Factory ${ }^{8},{ }^{12}$ at the south end of James bay.

The Ontario form is considered to be trichas brachidactyla.

Carleton County, Mer Bleue--Set of three eggs in N.M.C. was taken on July 9 , 1908 , by C. H. Young.

Essex County, Point Pelee-Nest with three eggs plus egg of Cowbird in R.O.M.Z. was taken by L. L. Snyder on June 26, 1920.

Frontenac County-Set of four eggs was found on July 10, 1920, by F. Starr at Hartington. At Kingston, E. Beaupre found a nest with four eggs on June 4,1922 .

Kenora District-Young birds collected in August, 1919, by D. Blakely at Lac Seul are in N.M.C. E. Keighley found a nest with three eggs in July, 1930, on Echlin's island, seven miles from Kenora. It nested commonly ${ }^{29},{ }^{190}$ in 1920 on the Ontario side of Indian bay, Lake of the Woods, according to letter from W. Rowan. 
Muskoka District, Port Sydney-Nest in R.O.M.Z. was taken by L. L. Snyder on June 28, 1919.

Norfolk County, Turkey point-Nest with four eggs in R.O.M.Z. was taken on June 1, 1933, by J. Edmonds.

Renfrew County, Petawawa-Nest and five young in R.O.M.Z. were taken on June 28,1935 , by C. E. Hope.

Simcoe County, Wasaga beach-Nest with five eggs was found on June 9, 1921, by $\mathrm{P}$. Harrington.

Sudbury District, Chapleau-Nest with four eggs was found on June 15, 1937, by C. E. Hope. These are in R.O.M.Z.

York County-At Toronto, P. Harrington found young leaving nest on June 2, 1915. E. Dixon has nests with three eggs from Reesor lake and Unionville.

\section{AMERICAN CHAT ICTERIA VIRENS}

The Chat occurs rarely in Ontario north to Middlesex ${ }^{22}$ and east to Peel County (pair seen at Erindale on several occasions from June 17 to 27,1934 by H. R. Ivor, J. L. Baillie and others).

It is known to breed only in Essex ${ }^{88}$ and Elgin Counties.

Our form is the typical one, virens virens.

Elgin County, Port Burwell-Set of three eggs plus egg of Cowbird was taken on June 14, 1924, by F. Starr.

\section{BLACK-CAPPED WARBLER WILSONIA PUSILlA}

The Black-capped Warbler is an uncommon summer resident in parts of Thunder Bay ${ }^{19}$, Sudbury and Cochrane Districts ${ }^{12},{ }^{21}$ and probably throughout the more northern parts of the province ${ }^{9}$.

It is known to breed only at Lake Abitibi and at Sudbury. At Sault Ste. Marie ${ }^{82}$ J. E. Cabot noted its presence during the summer of 1848.

Our form is pusilla pusilla, the Wilson's Warbler of most authors.

Sudbury District, Sudbury-Nest with five incubated eggs was collected on June 14, 1936, by F. Starr.

\section{CANADA WARBLER WILSONIA CANADENSIS}

This warbler is a well-distributed but not especially common summer resident of Ontario north to southern Kenora District and James bay ${ }^{12},{ }^{21}$.

It breeds north at least to the transcontinental line of the Canadian National Railway ${ }^{19},{ }^{22}$. D. R. Derry saw one on July 11, 1930, at Gorman creek, between Lat $53^{\circ}$ and $54^{\circ} \mathrm{N}$. on the Manitoba-Ontario boundary.

Haliburton District, Dysart township-Young bird being fed by parent was seen on August 7, 1935, by E. W. Calvert.

Kenora District, Kenora-Young were seen being fed by parents on July 27, 1931 by L. Paterson, according to the Winnipeg "Tribune" of September 12, 1931. 
Muskoka District, near Fox Point, Lake of Bays-Adults were seen feeding fledged young in early August, 1932, by T. F. McIlwraith.

Nipissing District, Eau Claire-Young were seen June 29-July 2, 1935, by T. M. Shortt.

Parry Sound District, Frank's bay, Lake Nipissing-D. A. MacLulich saw adult carrying food on July 2,1934 .

Sudbury District, Biscotasing-Young, in R.O.M.Z., was taken on July 8, 1937, by C. E. Hope.

Thunder Bay District, Port Arthur-Nest with two young a few days old was found on June 26, 1927, by L. S. Dear.

Victoria County, Bobcaygeon-Nest and five eggs were collected on June 10, 1932 , by F. Starr, who also saw a female attending young birds on July 20 , 1930 .

\section{AMERICAN REDSTART SETOPHAGA RUTICILLA}

The Redstart is probably the most common warbler of the province, breeding from the southern border north to James bay ${ }^{12},{ }^{21},{ }^{44},{ }^{81}$ and west to the southern Manitoba boundary ${ }^{29}$.

Cochrane District, Moose Factory—Nest with four eggs was found on June 25, 1930 , by S. Waller.

Frontenac County, near Collins' lake-Set of four eggs in R.O.M.Z. was taken on June 7, 1904, by E. Beaupre.

Haldimand County, near West Seneca marsh-Set of four eggs in R.O.M.Z. was collected by E. Reinecke on June 6, 1891 .

Kenora District, Kenora-Young being fed by parents were seen on July 27, 1931 , by L. Paterson, according to the Winnipeg "Tribune" of September $12,1931$.

Kent County-Very common at Rondeau in early June, 1933 and a set of four eggs was taken by us on the 2 nd. On the 12 th we saw a nest with young. W. E. Saunders has a set of four eggs taken at Fargo on June 3, 1902.

Muskoka District-Set of four eggs in R.O.M.Z. was taken on June 24, 1920, by B. A. Bensley at Go Home bay. At Robinsdale, A. W. Needler examined a nest with three eggs plus a Cowbird's egg on June 16, 1923.

Nipissing District-Breeds at Temagami, according to A. F. Coventry. At North Bay S. L. Thompson found a nest with four eggs on June 14, 1904.

Simcoe County, Wasaga beach-Set of five eggs was taken on June 9, 1927, and a nest with three young was seen on July 25,1914 , by P. Harrington.

Thunder Bay District, Port Arthur-Set of four eggs was taken on June 17, 1923 , by L. S. Dear.

York County, Toronto-Nest with one egg plus Cowbird egg was shown to J. L. Baillie by R. J. Rutter at Humber river on May 30, 1934, and a set of four eggs in R.O.M.Z. was collected by G. F. Dippie on June 15, 1894. At High Park, S. C. Downing found a nest with young on June 23, 1934. A nest with two eggs plus two eggs of Cowbird in R.O.M.Z. was taken at Scarboro Bluffs on June 20,1909 , by L. B. Brown.

\section{ENGLISH SPARROW PASSER DOMESTICUS}

This resident species, introduced into Ontario about 1870, is now found very commonly in suitable places throughout the whole of the 
province", 12, probably breeding wherever it occurs, although we are aware of no nesting records north of I ake of the Woods and Kapuskasing.

The North American race is domesticus domesticus.

Cochrane District, Kapuskasing-Bred in some numbers during the summer of 1928, according to W. J. Garnett.

Essex County, Point Pelee-Nest and four eggs taken on July 2, 1920, by L. L. Snyder are in R.O.M.Z.

Frontenac County, Portsmouth-Set of four eggs in R.O.M.Z. was taken on April 28, 1896, by E. Beaupre.

Huron County, West Wawanosh township-Set of four eggs was taken on July 20 and set of five eggs on July 6, 1935, according to R. Smyth.

Kenora District, Snowshoe bay, Lake of the Woods-Pair nested in 1920, according to letter from W. Rowan.

Ontario County-Three young were found in nest at Thorah island, Lake Simcoe, on June 8,1914 , by P. Harrington, and at Beaverton J. A. Edwards found a set of five eggs on June 28, 1910.

Renfrew County, Rankin to Shady Nook-Young were seen on June 25, 1935, by R.O.M.Z. field-party, L. L. Snyder, C. E. Hope and T. M. Shortt.

Simcoe County-Set of five eggs in R.O.M.Z. was taken on May 30, 1921, at Barrie and nest with four young was found at Wasaga beach on July 1 , 1913 , by P. Harrington. Nest with four eggs was found at Midland on June 30,1935 , by R. Standfield.

Thunder Bay District, Port Arthur-Breeds very commonly, according to L. S. Dear.

York County, Toronto-Nest with six eggs was seen on April 24, 1914, by P. Harrington and a nest with young on August 12, 1937, by J. L. Baillie.

\section{BOBOLINK DOLICHONYX ORYZIVORUS}

The Bobolink is a common summer resident of the more southern parts ${ }^{141}$ of the province, breeding north at least to southern Sudbury District ${ }^{39},{ }^{104},{ }^{110}$ and Ottawa ${ }^{23}$ and occurring in summer (and probably breeding) north to Nipissing District (one in R.O.M.Z. shot at Nosbonsing on July 2, 1935, by T. M. Shortt) and to Port Arthur (first seen during summer of 1932 , according to L. S. Dear).

Its occurrence as far north as Moose Factory (one shot by Robert McLeod on Hudson's Bay Company's field) is attested by S. Waller.

Durham County, Cartwright township, Lake Scugog-Young out of nest were seen on July 2, 1924, by E. W. Calvert.

Elgin County, Port Burwell-Set of six eggs was taken on June 5, 1924, by F. Starr.

Frontenac County, Simcoe island-Set of five eggs in R.O.M.Z. was taken by C. K. Clarke on May 31, 1899, and C. J. Young found a nest with two eggs on June 25, 1896.

Lincoln County, Niagara-on-the-Lake-W. P. Young took a set of five eggs on June 23, 1926. 
Middlesex County, London-Set of six eggs was taken in June, 1914, by W. E. Saunders.

Ontario County, Thorah island, Lake Simcoe-Set of five eggs was taken on June 1, 1913, by J. A. Edwards.

Simcoe County, Barrie-Set of five eggs was taken by H. P. Bingham on July $12,1919$.

Sudbury District, Bigwood-Young, just out of nest, were seen on July 20, 1937, by C. E. Hope.

Victoria County, Woodville-Set of four eggs was taken on June 22, 1930, by F. Starr.

York County-Set of five eggs was taken at Toronto on July 1, 1895, by J. L. Jackson. At Armour Heights, O. E. Devitt found a nest with five small young on June 29, 1935, and a nest with six eggs on May 27, 1936.

\section{EASTERN MEADOWLARK STURNELLA MAGNA}

The Eastern Meadowlark is a common breeding summer resident of southern Ontario ${ }^{51}$ north to Lake Nipissing ${ }^{41}$ extending northward rarely as far at least as Englehart, near Heaslip ${ }^{89}$, in Temiskaming District and west at least to the eastern end of Lake Superior ${ }^{49}$.

Our form is magna magna but the Meadowlark breeding in extreme western Ontario is more than likely the Western Meadowlark, Sturnella neglecta, as it is the species summering at Port Arthur (according to L. S. Dear) and at Goldpines, Kenora District (according to Mrs. F. C. Rust) as well as in Manitoba ${ }^{44}$ and Wisconsin ${ }^{49}$. There is no breeding evidence for Ontario of which we are aware, however, for the western species.

Frontenac County, Kingston township-Set of four eggs in R.O.M.Z. was taken on May 20, 1905, by McConnell and E. Beaupre took a set of six eggs (in R.O.M.Z.) on June 10, 1898.

Grenville County, Algonquin-Set of five eggs, in R.O.M.Z., was taken by S. C. Downing on May 10, 1937.

Grey County, Meaford-Nest with four eggs was found on June 1, 1936, by L. H. Beamer.

Hastings County, near Trenton-Set of four eggs in R.O.M.Z. was taken by W. H. Lunn on May 15, 1921.

Huron County, Brussels-Nest with two eggs was found on May 12, 1925, and nest with four eggs on July 4, 1923, by C. H. D. Clarke.

Kent County, Rondeau-Set of five eggs was taken on June 10, 1933, by us.

Nipissing District, North Bay-On June 16, 1925, young just able to fly were seen by W. E. Ricker.

Wellington County, Guelph-Nest with four eggs in R.O.M.Z. was taken on May 24, 1922, by W. J. LeRay.

Wentworth County, Hamilton-Nest with five eggs was found on May 30, 1923, by R. O. Merriman and a nest with four young was found in June, 1930, by P. Henderson.

York County, Toronto-Nest with six eggs was found on June 3, 1914, by P. Harrington. In R.O.M.Z. there is a set of four eggs taken on Jủne 27, 1891, by J. L. Jackson, and C. W. Nash found a nest with five eggs on May 4, 1890. 


\section{RED-WINGED BLACKBIRD AGELAIUS PHOENICELS}

The Redwing is a common breeding bird in suitable marshy ground from our southern border north at least to the Transcontinental railway ${ }^{31}$ (C.N.R.) and west at least 10 western Kenora District ${ }^{29}$ (Lat. 5.3 N.). A specimen in R.O.MI.\% taken at Monse Factory on May 30, 1930, by S. Waller sugerests that its breeling range extends northward to James bay.

The race occupying most of Ontario is the typical form, phoeniceus phoeniceus, hut the race loreeding at Lake Nipigon ${ }^{19}$ has been identified as phoeniceus arctolesus.

Cochrane District, Timmins-Mrs. G. Roach found the species nesting in June, 1936, according to J. M. Speirs.

Essex County, Point Pelee-Nest with four eggs was found on June 6, 1932, by J. L. Baillie.

Frontenac County, Kingston-Set of five eggs in R.O.M.Z. was taken on May 20,1897 , by E. Beaupre and set of five eggs in R.O.M.Z. was taken on June 10,1899 by $\mathrm{H}$. Clarke.

Kenora District-D. R. Derry found it nesting at Gorman lake (approximately Lat. $53^{\circ} \mathrm{N}$. on Manitoba-Ontario boundary) on July 7, 1930, and nest with three eggs was found on June 7,1931 , at Kenora by L. Paterson, according to B. W. Cartwright.

Lincoln County, St. Catharines-Nest with four eggs was found on May 25, 1936, by G. J. Clout.

Parry Sound District, Frank's bay, Lake Nipissing-Nest and three eggs taken by C. H. D. Clarke on May 28, 1933, are in R.O.M.Z.

Peterborough County, Lakefield-Nest with one egg was found by J. L. Baillie on July 7, 1923.

Thunder Bay District, Whitefish lake-Nest with five eggs was found on May 31,1935 , by us.

Wellington County, Elmira-Nest with young was found by G. W. Knechtel on June 10, 1928.

York County, Toronto-Nest with four eggs was found on May 9, 1919, by P. Harrington, and on June 25, 1934, at Humber river, C. E. Hope found a nest with four eggs. C. G. Harbour found a nest with six eggs at Humber river on June 3, 1911, and a set of six eggs in R.O.M.Z. was taken at Kelly lake on May 26, 1935, by May Halliday. A nest with three eggs in R.O.M.Z. was taken on July 2, 1905, by L. B. Brown.

\section{ORCHARD ORIOLE ICTERUS SPURIUS}

This oriole is confined to the southern edge of the province, breeding north to Lambton ${ }^{122}$ and Middlesex ${ }^{22}$ and east at least to Durham County (one seen near Mitchell's gardens by F. J. A. Morris). It is fairly common in some places along Lake Erie but elsewhere it is rare. The most northern place of occurrence appears to be Huron County (adult seen on August 18, 1925 and one on May 9, 1927, at Goderich by C. H. D. Clarke). 
Elgin County, Port Burwell-Set of five eggs was taken on June 18, 1924, by F. Starr.

Essex County-Set of four eggs was taken by us at Pelee island on June 5, 1933. At Point Pelee, L. L. Snyder took a nest and three eggs, plus egg of Cowbird, (in R.O.M.Z.) on June 14, 1920.

Kent County, Chatham-A set of four eggs ${ }^{170}$ in N.M.C. was collected by T. Smith on June 30, 1887.

Lincoln County, Vineland-Nests regularly and young were seen by W. E. Hurlburt at nest on June 30, 1929. A nest in R.O.M.Z. was used in 1930 to rear a brood of young, according to Hurlburt.

Norfolk County, Port Dover-Adults were seen at nest on June 28, 1934, by J. M. Speirs.

Wentworth County, Hamilton-Young left a nest on June 28, 1937, according to G. W. North, the nest found by J. M. Speirs on June 23, 1937, with young.

York County, Toronto-Nest was found on July 5, 1900, by J. H. Samuel.

\section{BALTIMORE ORIOLE ICTERUS GALBULA}

The Baltimore Oriole is a fairly common breeding bird in southern Ontario north to Parry Sound District ${ }^{110}$ and Ottawa ${ }^{23}$.

It also breeds fairly plentifully in the Lake of the Woods vicinity ${ }^{29}$ of Manitoba, but not in the intervening territory between there and Parry Sound, so far as we are aware, although a male was seen by us at Whitefish lake, near Port Arthur, on June 6, 1935, and its occurrence at Goldpines, Kenora District, is attested by Mrs. F. C. Rust.

Durham County, Hampton-Nest was found on June 18, 1927, by A. E. Allin. Frontenac County, Simcoe island-Set of six eggs taken on June 4, 1898 by C. K. Clarke is in R.O.M.Z.

Halton County, Twelve-mile creek-Young were seen on June 26, 1926, by T. F. McIlwraith and J. L. Baillie.

Middlesex County, Coldstream-Set of three eggs in R.O.M.Z. was collected on June 5, 1913, by A. A. Wood.

Ontario County, Beaverton-Set of five eggs was taken on June 7, 1920, by J. A. Edwards.

Peel County, Erindale-Adults were seen with half-grown young on July 4, 1934, by J. L. Baillie.

Prescott County, Hawkesbury-Egg in collection of R. Kirby was examined by S. C. Downing.

Simcoe County, Barrie-Nest with four eggs was seen on June 4, 1915, by H. P. Bingham.

Victoria County, Bobcaygeon-Set of five eggs was taken by us on June 8, 1932 .

York County-J. H. Samuel found a nest with four eggs on May 31, 1899 at Eglinton ravine, Toronto. J. M. Speirs saw a nest with young on Wolfrey avenue, Toronto, on June 26, 1935, (young left on the 29th) and E. Dixon has a set of six eggs plus Cowbird egg from Unionville.

\section{RUSTY BLACKBIRD EUPHAGUS CAROLINUS}

The Rusty Blackbird is not known to have nested in Ontario south of Grey County and Algonquin Park, but it is a fairly common breeding 
species north from there throughout most, if not all, of northern Ontario ${ }^{9},{ }^{12},{ }^{14},{ }^{25},{ }^{31}$.

Algoma District, Amyot-Nest with four young in R.O.M.Z. was secured on June 27, 1936, by C. E. Hope and S. C. Downing.

Cochrane District-Juveniles were seen on July 28, 1933, at Smoky Falls, north of Kapuskasing, by R. V. Whelan. A. V. Dukes collected eggs at Lake Abitibi, according to E. Dixon.

Grey County, Durham-Nest with four eggs was found in early July, 1910, by C. G. Watson. He has the male parent in his possession.

Nipissing District, Tea lake, Algonquin Park-Nest with parent feeding young was found on July 7, 1926, by Eleanor Thompson.

Sudbury District, Bigwood-Young, in R.O.M.Z., was secured by C. E. Hope on July $15,1937$.

Thunder Bay District-Nest with five young, in R.O.M.Z., was found on June 18, 1936 , by P. Harrington at Peninsula. Adults were seen feeding young (now in R.O.M.Z.) on July 8, 1937, by L. L. Snyder and T. M. Shortt.

\section{CROW BLACKBIRD QUISCALUS QUISCULA}

This bird is one of the most common and widely distributed birds of the province, breeding from the southern border north at least ${ }^{12}$ to Cochrane District and west to Lake of the Woods ${ }^{29}$, and probably considerably farther, as D. R. Derry found them to be common along the Manitoba-Ontario boundary between Lat. $53^{\circ}-54^{\circ} \mathrm{N}$. during the summer of 1930 .

Our form is the Bronzed Grackle of most authors, quiscula aeneus.

Algoma District, Amyot-Nest with two young, in R.O.M.Z., was collected on June 29, 1936, by C. E. Hope.

Cochrane District, Smoky Falls, north of Kapuskasing-Set of five eggs was found on May 22, 1933, by R. V. Whelan.

Essex County, Pelee island-Nest with two eggs was found by us on June 3, 1933; on the 5th flying young were seen.

Frontenac County-Set of four eggs in R.O.M.Z. was taken at Kingston by C. M. Clarke on April 27, 1898, and set of four eggs in R.O.M.Z. was taken by E. Beaupre on May 16, 1903, at Horseshoe island.

Kenora District, Ontario side of Indian bay, Lake of the Woods-Large colony bred in 1920, according to letter from W. Rowan.

Manitoulin District, McGregor bay-Set of four eggs in R.O.M.Z. was taken on June 23, 1924, by B. A. Bensley.

Parry Sound District, Patterson township-Nest with four eggs was found on June 11, 1933, by C. H. D. Clarke. The nest is in R.O.M.Z.

Peterborough County, Otonabee river-Nest with five eggs was taken by S. C. Downing on May 16, 1935.

Thunder Bay District, Port Arthur-Set of five eggs was taken by L. S. Dear on May 28, 1922.

York County, Toronto-Nest with six eggs in R.O.M.Z. was taken on April 26, 1924 , by T. Dockray. A set of four eggs in R.O.M.Z. was taken at Woodbine on July 3, 1891, for J. D. McMurrich. 


\section{COWBIRD MOLOTHRUS ATER}

In southern Ontario the Cowbird is a common breeding species, and although it occurs northward to Moose Factory ${ }^{12},{ }^{19}$ and west to Lake of the Woods, it is not common in the northern parts of its range, excepting in the extreme west ${ }^{29}$. It has been found breeding throughout its range (female in R.O.M.Z. taken on June 13, 1930, by S. Waller).

We have in this paper recorded instances of this bird parasitizing at least forty-one species in this province, and to these can be added fifteen species, already on record, as follows: Scarlet Tanager ${ }^{22}$, Blue-gray Gnatcatcher ${ }^{22}$, Yellow-throated Vireo ${ }^{22}$, Canada Warbler ${ }^{22}$, Eastern Meadowlark ${ }^{22}$, Warbling Vireo ${ }^{22}$, Wood Thrush ${ }^{22}$, Bobolink ${ }^{50}$, Slatecoloured Junco ${ }^{50}$, Golden-winged Warbler ${ }^{28}$, Blackburnian Warbler ${ }^{215}$, Kingbird ${ }^{216}$, Pine Siskin ${ }^{200}$, Prairie Warbler ${ }^{87}$ and Cerulean Warbler ${ }^{217}$, making fifty-six species in all. In this connection, it is of interest to note Hicks' statement ${ }^{206}$ that forty-two species are known to have been hosts to this species in Ohio. Our earliest record of egg-laying is April 26, 1925 and the latest July 21, 1930.

Our form is considered to be ater ater.

Durham County, Hampton-Egg in R.O.M.Z. was taken from nest of Goldfinch on July 21, 1930, by A. E. Allin.

Essex County, Point Pelee-Egg in R.O.M.Z. was taken from the nest of a Yellow Warbler on June 14, 1920, by L. L. Snyder and two eggs in R.O.M.Z. were taken by him on July 5,1920 , from nest of an Indigo Bunting.

Kenora District, Ontario side of Indian bay, Lake of the Woods-Bred abundantly in 1920, according to letter from W. Rowan.

Kent County, Rondeau-Two imbedded eggs were found by us in the nest of a Yellow Warbler on May 21, 1934; on June 12, 1933, we found an egg in the nest of a Cardinal.

Nipissing District-At Eau Claire a young bird was found in the nest of a Blackthroated Blue Warbler by T. M. Shortt June 29-July 2, 1935, and at North Bay a young bird was seen with a Robin in attendance on June 15,1925 , by W. E. Ricker.

Ontario County-P. Harrington found a young one in the nest of a Song Sparrow at Thorah island, Lake Simcoe on May 14, 1915, and at Pickering young was seen attended by a Chipping Sparrow on August 27, 1926, by J. L. Baillie.

Renfrew County, Petawawa-Egg was found in the nest of a Hermit Thrush on June 1, 1916, by P. Harrington.

Simcoe County-On May 21, 1932, J. L. Baillie found an egg at Minesing in the nest of a Robin and on July 17, 1914, P. Harrington found an egg in the nest of a Myrtle Warbler at Wasaga beach.

Thunder Bay District, Port Arthur-Egg was found in the nest of a Swamp Sparrow on June 6,1924, and an egg in the nest of a Red-eyed Vireo on June 24, 1923, by L. S. Dear.

York County-At Toronto, P. Harrington found an egg in the nest of a Phoebe on May 7, 1915, and at Donlands, J. L. Baillie saw a young one being fed by 
a Song Sparrow on August 14, 1924. At Weston, H. Ing took a nest with two eggs of Song Sparrow plus three eggs of Cowbird on May 4, 1933, (in R.O.M.Z.) and at Toronto, R. V. Lindsay found a nest of Song Sparrow with two eggs plus Cowbird's egg on April 26, 1925.

\section{SCARLET TANAGER PIRANGA ERYTHROMELAS}

The Scarlet Tanager occurs in the deciduous and mixed forests of Ontario (fairly numerous in the southern half of the province), north ${ }^{15}$ to Lake of the Woods ${ }^{29}$, Temagrami (male was seen on July 6, 1930 in Latchford township by A. F. Coventry) and Timmins, southern Cochrane District (noted on June 3, 1936 by Leonard Berry).

It breeds north at least ${ }^{15},{ }^{95}$ to Goulais bay, near Sault Ste. Marie, Algoma District ${ }^{90}$ and Algonquin Park, and probably westward to Lake of the Woods (family encountered in 1920 at Falcon bay, Lake of the Woods, Manitoba, by W. Rowan).

Elgin County, Aylmer-Set of four eggs in R.O.M.Z. was taken by R. T. Anderson.

Frontenac County, Murvale-Set of four eggs in R.O.M.Z. was collected on June 12, 1905, by E. Beaupre.

Muskoka District, Beausoleil island-Nest with four young was found by D. M. Scott in July, 1936.

Nipissing District, Brule lake, Algonquin Park-Adults were seen feeding young on August 10, 1934, by C. H. D. Clarke.

Norfolk County-Found nesting by C. W. Nash.

Parry Sound District-Nest and egg taken at Emsdale on June 5, 1893, by J. H. Fleming are in R.O.M.Z. At Sundridge, J. M. Speirs saw young in July, 1931, and nest and one egg in R.O.M.Z. were taken at Frank's bay, Lake Nipissing on August 29, 1930, by F. E. J. Fry, A. M. Fallis and J. G. Oughton.

Peel County, Erindale-Nest ${ }^{222}$ was found in 1929 or 1930 , and another in 1931 by H. R. Ivor.

Simcoe County-Nest (just started) was found on June 9, 1923, by P. Harrington at Wasaga beach and at Barrie a set of four eggs was taken by H. P. Bingham on June 2, 1918.

Wentworth County, Ancaster-On July 13, 1935, three young were flushed from nest by B. Ronald and D. Hassell.

York County, near Kelly lake-R. D. Ussher found a nest with three eggs on June 10, 1937.

\section{CARDINAL RICHMONDENA CARDINALIS}

The Cardinal is a not uncommon summer resident of certain localities in southern Ontario, north at least to Simcoe County and east to Carleton County ${ }^{23},{ }^{101}$. It has been known to occur accidentally north to Algoma ${ }^{92}$ and Parry Sound Districts (female in Normal School, North Bay, was secured at Hardy bay, on French river in autumn about 1930 by Dr. 
F. W. Mckee). Its known breeding range lies south and west of Toronto ${ }^{91}$.

Our form is the typical one, cardinalis cardinalis.

Brant County, Brantford-Pair nested on L. Harris' property in 1919, according to W. G. Neff.

Elgin County, St. Thomas-Nest with young was found on May 6, 1932, by Irla Flack.

Essex County, Point Pelee-Set of two eggs plus Cowbird's egg was taken on May 15, 1911, by W. E. Saunders. A set of three eggs in R.O.M.Z. was taken on June 15,1920 , by L. L. Snyder.

Kent County, Rondeau-On June 2, 1933, we were shown a nest with three eggs plus egg of Cowbird by C. C. Bell and on the 12th we found a nest with two eggs plus a Cowbird's egg.

Middlesex County, Coldstream-In the summer of 1927, A. A. Wood saw three young birds just fledged.

Welland County, near Port Colborne-W. P. Young took a set of three eggs on June 20, 1925 .

Wentworth County, Westdale park, Hamilton-Nest with two young was found on June 8,1935 by G. W. North, D. M. Scott and P. Henderson.

York County, Toronto-A nest with three young was reported at Ward's island in June, 1928. R. J. Rutter found a nest with two eggs in the Don valley on May 7, 1933. In August, 1928, B. Wood saw three young with parents in Nordheimer's ravine, and on August 28, 1929, B. Penlington encountered three young about two weeks out of nest at Toronto Hunt Club property. The latter were from a nest begun on May 24 .

\section{ROSE-BREASTED GROSBEAK HEDyMELES LUDOVICIANUS}

This bird occurs as a fairly common summer resident throughout southern Ontario, breeding north to the transcontinental line of the Canadian National Railway, and probably west to Lake of the Woods ${ }^{29}$ (few pairs found breeding in 1920 at Indian bay, Manitoba, by W. Rowan).

Elgin County, St. Thomas-Set of four eggs in R.O.M.Z. was taken on May 10, 1905 , by R. W. Johnson.

Frontenac County, Sharbot lake-Set of five eggs in R.O.M.Z. was taken on June 5, 1905, by E. Beaupre.

Grey County, Orchardville-A nest with three eggs in R.O.M.Z. was taken on June 6,1906 , by L. B. Brown.

Leeds County-Nest with one egg and two young was found by E. Beaupre on June 11, 1896.

Middlesex County, Coldstream-Set of five eggs plus egg of Cowbird in R.O.M.Z. were taken on June 8,1917 , by A. A. Wood.

Parry Sound District, Pickerel lake, east of Burk's Falls-Female was seen feeding a fully-grown young bird on July 16, 1935, by J. L. Baillie.

Simcoe County-Set of four eggs plus two Cowbird's eggs was taken by us on June 7, 1929, at Orr lake. At Barrie a set of four eggs was taken on June 4, 1916, by H. P. Bingham. 
Thunder Bay District, Port Arthur-Set of four eggs was taken on July 4, 1928, by L. S. Dear.

Victoria County, Bobcaygeon-Nest with two eggs in R.O.M.Z. was secured on June 11, 1931, by A. E. Allin.

Wellington County, Mount Forest-A nest with four eggs in R.O.M.Z. was taken on May 30, 1904, by H. Skales.

\section{INDIGO BUNTING PASSERINA CYANEA}

The Indigo Bunting is a fairly common and well-distributed summer resident of southern Ontario north to Lake Nipissing and Ottaw ${ }^{23},{ }^{39}, 150$ breeding throughout its range but much more commonly along the southern edge of the province.

In extreme western Ontario, it occurs in summer and probably breeds, as a male was seen at Sioux Lookout, Kenora District, in June by Miss $\mathrm{E}$. Keefe, according to A. G. Lawrence, and one was seen by us in June, 1935, at Whitefish lake, near Port Arthur. Besides this, it is known to breed in Minnesota counties ${ }^{176}$ immediately to the south of extreme western Ontario and C. H. D. Clarke observed a male at Pancake bay, southern Algoma District, on July 29, 1935. Also its occurrence at Sudbury, Sudbury District ${ }^{16}$ is recorded in the summer of 1889.

Elgin County, Aylmer-Set of two eggs in R.O.M.Z. was taken on June 17, 1896 , by R. T. Anderson.

Essex County, Point Pelee-Set of four eggs in N.M.C. was taken on June 7, 1913, by P. A. Taverner and C. H. Young.

Frontenac County, Hartington-Young, just fledged were found on July 17, 1920 , by F. Starr.

Lincoln County-G. J. Clout found a nest with one egg plus two Cowbird's eggs at Decew Falls on June 27, 1936, and a nest with eggs and one young at Rockway on July 22, 1936.

Middlesex County, Byron-G. W. Knechtel found a nest with one egg and two Cowbird's eggs on June 14, 1928.

Muskoka District, Torrance-J. M. Speirs saw two young out of the nest, with parent, on August 17, 1936.

Nipissing District, Algonquin Park-Few breed, according to M. Robinson.

Ontario County-A set of two eggs was taken on July 24, 1909, by J. A. Edwards at Beaverton and a nest with three eggs in R.O.M.Z. was taken by L.L. Snyder at Rouge hills on June 23, 1932.

Simcoe County, Barrie-H. P. Bingham took a set of four eggs on June 7, 1913.

York County, Toronto-J. L. Jackson took a set of four eggs (in R.O.M.Z.) on July 19,1890 , and a set of three eggs was taken by J. A. Edwards on June 10,1911 .

\section{DICKCISSEL SPIZA AMERICANA}

The Dickcissel is a very rare summer resident of the extreme southwestern counties ${ }^{166}$ of Ontario (east to Ottawa, two records ${ }^{140},{ }^{223}$ ). 
There is only one recent nesting record (given below) but the species has been recorded as breeding in the past in Elgin ${ }^{128}$, Essex $^{148}$, Lambton $^{122}$ and Middlesex Counties ${ }^{22}$.

Essex County, Point Pelee-Pair was seen with four young on June 27, 1936, by J. M. Speirs.

\section{EVENING GROSBEAK HESPERIPHONA VESPERTINA}

The Evening Grosbeak is an uncommon and locally distributed summer resident of a narrow belt of Ontario extending from western Algonquin Park ${ }^{108},{ }^{112}$ north and west to Lake of the Woods ${ }^{29},{ }^{149}$ where the initial nesting record for the province was established by W. Rowan in 1920. In addition it is known to breed in Cook County, Minnesota ${ }^{176}$ adjacent to Ontario, at the west end of Lake Superior. One female was seen on August 16, 1936, by L. L. Snyder at Haliburton, Haliburton District.

Our race is presumably vespertina vespertina.

Algoma District, Bachawana bay-Young were seen with adults in August, 1935, by C. H. D. Clarke.

Kenora District-Adult was seen feeding a young bird on July 24, 1920, at the Ontario side of Indian bay, according to letter from W. Rowan, and at Kenora L. Paterson saw young birds being fed by parents on September 5, 1931.

Nipissing District, Brule lake, Algonquin Park-Juvenile female in R.O.M.Z. was collected on August 1, 1934, by C. H. D. Clarke.

Parry Sound District, Pickerel lake, east of Burk's Falls-Juvenile male in the collection of J. H. Fleming was taken by J. L. Baillie on August 7, 1934. It was one of three young being fed by parents. Another young, taken by Baillie on August 1, 1936, and also in the Fleming collection, was from a brood attended by parents.

Sudbury District, Bigwood-Young, in R.O.M.Z., were secured with parents on August 2, 1937, by S. C. Downing.

Thunder Bay District, Port Arthur-Brood of three young (one week out of nest) was seen on July 29, 1933, by L. S. Dear.

\section{COMMON PURPLE FINCH CARPODACUS PURPUREUS}

The Purple Finch is a fairly common summer resident of Ontario (particularly in the central and northern parts) from our southern border north to Lake of the Woods ${ }^{29}$ and James bay ${ }^{12}$.

It is known to nest north to the transcontinental line of the Canadian National Railway ${ }^{31}$ and west at least to Kenora, Kenora District.

The form in Ontario is the eastern race, purpureus purpureus.

Algoma District, Mississagi Forest reserve-Female was seen feeding a fullygrown young bird on July 22,1923 , by R. D. Ussher. 
Cochrane District, Smoky Falls, north of Kapuskasing-Egg in R.O.M.Z. was taken on June 16,1934, by R. V. Whelan.

Elgin County, St. Thomas-Set of five eggs was taken on June 2, 1890, by F. L. Farley. This is set number 3865 in the collection of W. E. Saunders.

Frontenac County, Kingston-Egg was taken on June 1, 1922, by E. Beaupre, who saw adults feeding young on June 20, 1921.

Hastings County, Trenton-A nest with four incubated eggs was found by W. H. Lunn on June 28, 1936.

Kenora District, Kenora-Breeds, according to Mrs. C. Ratchford.

Parry Sound District, Katrine-Nest and three eggs in R.O.M.Z. were secured on June 28,1932 , by R. J. Rutter.

Renfrew County, Petawawa-Set of five eggs was found on June 10 and a set of three eggs on June 4, 1916, by P. Harrington.

Simcoe County, Barrie - Set of four eggs was taken on July 15, 1915, by H. B. Haugh, and a set of five eggs on June 18, 1916, by H. P. Bingham.

Thunder Bay District, Whitefish lake-Nest with five eggs was found on June 10, 1935, by L. S. Dear; the nest is in R.O.M.Z.

\section{PINE SISKIN SPINUS PINUS}

The Siskin is typically a nomad, occurring irregularly and not uncommonly throughout Ontario ${ }^{109}$, north at least to the transcontinental line of the Canadian National Railway ${ }^{19}$. It probably breeds throughout its range ${ }^{12}$, although there is no evidence of its doing so in more than a few localities, where at times they nest ${ }^{142},{ }^{71},{ }^{199}, 200$ rather commonly (e.g. Carleton and Wellington Counties).

L. L. Snyder and T. M. Shortt, of R.O.M.Z., found Siskins to be common at Ingolf, extreme western Kenora District (Lake of the Woods) in June, 1937, and it was found frequently during the summer of 1920 at Indian bay ${ }^{29}$, Lake of the Woods, Manitoba, by W. Rowan and Roberts ${ }^{176}$ gives a record of its nesting in St. Louis County, Minnesota, adjacent to Lake of the Woods, Ontario.

Algoma District, Bachawana bay-Young bird was taken from flock on August 7, 1935, by C. H. D. Clarke.

Carleton County, Billing's bridge-Set of five eggs in N.M.C. was taken on July 22, 1914, by C. L. Patch. These eggs, compared with Siskin eggs from Wolfville, Nova Scotia (in the same collection) agree in markings, size, etc.

Halton County, Oakville-Nests, and two sets of eggs were found in spruces by J. P. Turner, according to journals of J. H. Samuel, 1899.

Muskoka District, Port Sydney-Breeds, according to A. Kay.

Parry Sound District-E. Dixon has a set of four eggs.

Victoria County-Nest with four newly-hatched young was found at Woodville on April 18, 1927, by F. Starr. On April 3, of the same year, we found a newly-completed nest at Pottageville, York County. Siskins were common at both places during that month. At Bobcaygeon (Victoria County), F. Starr found young flying on May 28, 1933. 
York County-At East York township R. J. Rutter found a pair building nest about May 1, 1929, and in March, 1895, at Ramsey Estate, Heath Street, a nest with two eggs was taken and sent to T. Mcllwraith by W. Carrell.

\section{AMERICAN GOLDFINCH SPINUS TRISTIS}

The American Goldfinch is a common summer resident of the province north to the Transcontinental railway (C.N.R.) ${ }^{29},{ }^{31}$ and west to Thunder Bay District, breeding north at least to Algonquin Park, southern Algoma District and Port Arthur and probably throughout its range ${ }^{14},{ }^{23}$. W. Rowan found it to be breeding plentifully in the summer of 1920 at Indian bay, Lake of the Woods, Manitoba and it breeds in Minnesota ${ }^{176}$ adjacent to Lake of the Woods.

Our form is the eastern Goldfinch, tristis tristis.

Algoma District, Bachawana bay-Young were seen being fed by parents on September 16, 1935, by C. H. D. Clarke.

Frontenac County, Portsmouth-Set of six eggs in R.O.M.Z. was taken on July 13, 1897, by E. Beaupre.

Huron County, West Wawanosh township-Set of four eggs was taken on August 8, 1934, according to R. Smyth.

Lincoln County, St. Catharines-Nest with four eggs was found by G. J. Clout on August 28, 1934; they were hatched on September 1st. On July 10, 1936, Clout discovered a nest with five eggs plus egg of Cowbird.

Ontario County, Beaverton-J. A. Edwards took a set of six eggs on July 21, 1909.

Peel County, Port Credit-A nest with five eggs, in R.O.M.Z. was secured on July 22, 1894, by J. Parke.

Simcoe County - Set of five eggs was taken at Wasaga beach on August 22, 1920, by $\mathrm{P}$. Harrington, who also took a set of six eggs on July 28, 1914. At Barrie, H. P. Bingham took a set of five eggs on July 13, 1915.

Sudbury District, Bigwond-Set of five eggs, taken on July 21, 1937, by C. E. Hope, is in R.O.M.Z.

Thunder Bay District, Port Arthur-L. S. Dear found nests with five and six eggs on July $31,1929$.

York County, Toronto-A set of five eggs was obtained by C. E. Hope on June 14, 1929, at Cedarvale. On August 27, 1915, P. Harrington took a set of four eggs at Toronto and at Ashbridge's bay, G. H. Richardson found a nest with eggs on September 5, 1932, and J. L. Baillie saw the four newly-hatched nestlings on the 18th. At Mount Dennis, C. E. Hope took a nest with six eggs plus imbedded Cowbird egg on July 19, 1935.

\section{RED CROSSBILL LOXIA CURVIROSTRA}

This is another of those erratic winged nomads which appears irregularly though quite rarely in various sections of Ontario ${ }^{21}$ north to Severn river emptying into Hudson bay ${ }^{25}$.

Its breeding range may include the whole of the province, but we 
are not aware that its nest has been discovered within our borders. Broods of young have been encountered in at least four counties, however, three of them south of Lake Nipissing, riz. Bruce ${ }^{93}$, Nipissing ${ }^{12}$ and York ${ }^{43}$ and in the north, Algoma District ${ }^{109}, 224$. A nest, possibly of this species, with three eggs plus egg of Cowbird is in collection of W. E. Saunders ${ }^{92}$. It was found on April 28, 1909, forty-five feet up in a maple tree by Harold J. Clarke at London, Middlesex County.

Our race is considered to be curvirostra pusilla by the American Ornithologists' Union Check-List (1931) yet adults and juveniles, taken at Lake Manitowick, northern Algoma District, in August, 1928, are called curitrostra minor by Griscom ${ }^{224}$. These specimens (in collections of Ohio State Museum and University of Michigan) were collected by W. G. Fargo and M. B. Trautman.

Muskoka District, Port Sydney—Breeds occasionally, according to A. Kay.

Nipissing District-Has been found nesting at Bertram's island, Canoe lake, Algonquin Park, by M. Robinson, and on July 2, 1900, W. Spreadborough found old and young birds in the Park.

York County, Lambton-One collected from a flock of five on May 26, 1894, was "quite a young bird" according to the journals of J. H. Samuel.

\section{WHITE-WINGED CROSSBILL LOXIA LEUCOPTERA}

The White-winged Crossbill is evidently more common than the Red Crossbill in Ontario. It has been found more or less commonly at various places north from Middlesex County ${ }^{22}$ to the northern limit of the province ${ }^{21},{ }^{94}$ in summer and west to the west end of Lake Superior ${ }^{176}$ (breeding in Cook County, Minnesota, adjacent to Ontario).

Although young birds have been found on several occasions, the finding of its nest has been but twice reported from Ontario ${ }^{109}$. One nest, containing three young, about ready to leave, was discovered fortyone feet up in a spruce tree at Michipicoten river (northern Algoma District) on August 20,1928, by Milton B. Trautman. The nest and its occupants are now in the Ohio State Museum, Columbus, Ohio. The other nest is recorded below. It should be noted that the Catalogue of the Collection of Birds' Eggs in the British Museum, Vol. 5, 1912, p. 226, records their possession of a single egg of this species from London, Ontario, received from the Tristram collection (Crowley bequest). No date or other information accompanies the entry.

Muskoka District, Port Sydney-Breeds occasionally, according to A. Kay.

Thunder Bay District, Murillo-Adults and flying young, in R.O.M.Z., were obtained by T. M. Shortt on July 23, 1937.

Victoria County, Head lake-Moderately common during the summer of 1926 , and a nest with eggs was found on August 19 in a small cedar, according to D. A. MacLulich. 


\section{EASTERN TOWHEE PIPILO ERYTHROPHTHALMUS}

The Towhee is a fairly common breeding species throughout southern Ontario north to Muskoka District ${ }^{39},{ }^{63},{ }^{154}$ and east at least to Leeds ${ }^{12}$ and Carleton Counties ${ }^{151},{ }^{223}$. Its nesting range in the province probably extends some distance to the northward, as there are records of its occurrence in Algoma District ${ }^{95}$.

Our form is the typical one, erythrophthalmus erythrophthalmus.

Huron County, West Wawanosh township-Set of one egg, plus egg of Cowbird, was taken on July 20, 1934, according to R. Smyth.

Kent County, Rondeau-Nest and one egg were found by us on June 2, 1933.

Lambton County, near Grand Bend-Nest with four eggs plus Cowbird's egg in R.O.M.Z. was taken on June 5, 1935, by C. E. Hope.

Lincoln County, near St. Catharines-Nest with four eggs as well as two eggs of Cowbird was found by G. J. Clout on May 24, 1934, and a nest with one young on July 18, 1936.

Middlesex County-Set of four eggs in R.O.M.Z. was taken on June 7, 1917, by A. A. Wood at Coldstream. At Byron, G. W. Knechtel banded four (week old) young in nest on June 14, 1928.

Peterborough County, Jack's creek, Stony lake-Juveniles were seen with parents on July 6,1921 , by J. L. Ballie.

Simcoe County-H. P. Bingham took a nest and four eggs on May 25, 1924, at Barrie, and P. Harrington took a set of three eggs at Wasaga beach on August 13, 1922.

Victoria County, Woodville-Set of three eggs plus egg of Cowbird was found by P. Harrington on June 5, 1932.

Wentworth County, Ancaster-A nest with four young was found on July 26, 1934, by D. Hassell and B. Ronald.

York County-Brood of four fledged young was seen at Lambton on August 19, 1923, by J. L. Baillie. At Toronto, C. G. Harbour found a nest with three eggs plus two Cowbird's eggs on May 18, 1912.

\section{SAVANNAH SPARROW PASSERCULUS SANDWICHENSIS}

The Savannah Sparrow is one of the most common of the breeding finches of Ontario, occurring in suitable places throughout the province 8,12 .

The form occurring here is probably sandwichensis savanna, although sandwichensis labradorius may replace it in the extreme northern sections of the province ${ }^{8}, 9$.

Its western limit is probably Lake of the Woods ${ }^{29}$ as W. Rowan found it to be quite numerous in the summer of 1920 at Indian bay, Manitoba, just beyond the borders of the province.

Algoma District, Amyot-C. E. Hope found a nest with four young on June 23, 1936.

Cochrane District-At Kapuskasing a juvenile (just out of the nest) was collected by C. E. Johnson on June 28, 1919. It is in N.M.C. At Moose Factory, S. Waller found a nest with six eggs on Mansy island. 
Durham County-At Orono, R. A. Smith found a nest with three eggs on May 6, 1935, and at Cartwright township, Lake Scugog, E. W. Calvert found a nest with three eggs on June 1, 1924.

Frontenac County, Simcoe island-Nest with three young and two eggs was found on May 14, 1898, by E. Beaupre and C. K. Clarke.

Kenora District, Wabigoon-T. M. Shortt found a nest with four eggs on June 21, 1937.

Lincoln County, St. Catharines-Nest with three eggs was found on June 28, 1936, by G. J. Clout.

Ontario County-J. A. Edwards took a set of four eggs at Beaverton on June 5, 1913, and at Port Whitby, H. K. Gordon found a nest with four eggs on July 21,1934 .

Peel County, Lakeview-Nest with five eggs was found on June 27, 1935, by C. E. Molony.

Thunder Bay District, Port Arthur-Set of four eggs was taken on June 11, 1924, by L. S. Dear.

York County-A nest with two eggs, plus egg of Cowbird, was seen by J. L. Baillie at Sunnyside, Toronto, on May 11, 1933, and a nest with five eggs was shown to him by F. H. Emery at Islington on June 4, 1931. At Toronto island, G. F. Dippie found a nest with four eggs on June 21, 1894, now in R.O.M.Z.

\section{GRASSHOPPER SPARROW AMMODRAMUS SAVANNARUM}

The Grasshopper Sparrow is a summer resident of southern Ontario (fairly common in the counties along Lake Erie), north to Grey (one seen at Thornbury on June 9, 1937, by R. M. Saunders), Simcoe (seen at Jack's lake on July 2, 1933, by O. E. Devitt and one seen at Penetang June 11-15, 1935, by C. E. Hope), Victoria (one seen near Bobcaygeon in June, 1931 by $\mathrm{P}$. Harrington) and east to Carleton Counties ${ }^{23}$.

It probably nests wherever it takes up its summer residence but actual breeding data are known only for Middlesex ${ }^{22}$, Elgin, Essex ${ }^{156}$ Haldimand and York Counties.

Our race is the eastern form, savannarum australis.

Elgin County, Copenhagen-Adults were seen feeding young on August 3, 1930, by R. V. Lindsay and on the 12th F. H. Emery found a nest with four eggs.

Haldimand County, Lowbanks-Nest with three young was found on July 9 , 1935 , by R. A. Smith.

Middlesex;County, Komoka-Young bird taken on August 2, 1894, is in W. E. Saunders' collection.

York County-At Lansing, H. M. Halliday and J. L. Baillie watched a pair carrying food in their mouths on July 28,1934 , and on July 4, 1935, O. E. Devitt located young birds being fed by their parents at Armour Heights, Toronto.

\section{LECONTE'S SPARROW PASSERHERBULUS CAUDACUTUS}

LeConte's Sparrow prior to 1937 was known to occur in summer only north of Lat. $48^{\circ} \mathrm{N}$. in Thunder Bay ${ }^{19},{ }^{98}$ and Algoma Districts ${ }^{109}$. 
It breeds in the former district and probably occupies much of extreme western Ontario, as it is a more or less comomn summer resident of adjacent southern Manitoba.

The occurrence of this sparrow in several sections of southern Ontario during the summer of 1937 (small colonies at Baden, Toronto, and Bradford, according to F. Barratt, J. M. Speirs and O. E. Devitt, respectively) suggests that their southern breeding limits require revision, particularly since a female, collected at Bradford on July 10 by O. E. Devitt, contained eggs almost ready for extrusion.

Thunder Bay District, Port Arthur-Quite plentiful; two sets of four eggs (one in R.O.M.Z.) were collected by L. S. Dear, June 10-11, 1924.

\section{HENSLOW'S SPARROW PASSERHERBULUS HENSLOWI}

The Henslow's Sparrow is a locally-distributed summer resident of extreme southern Ontario, breeding only south ${ }^{22}$ and west of York County ${ }^{96}$ and it has been actually found nesting in Peel ${ }^{96}$ (nest with four eggs on July 5, 1932), Norfolk ${ }^{27}$, Elgin, Kent ${ }^{97}$ (two nests with five eggs on June 17,1908 ) and York Counties.

It is not uncommon in certain places, and Sarnia ${ }^{12}$ in Lambton County and Bradford in Simcoe County (one taken on July 11, 1937, by O. E. Devitt) appear to mark its northern limit.

Our race is said to be the western form, henslowi henslowi.

Elgin County, Copenhagen-Nest and set of three eggs in R.O.M.Z. were taken ${ }^{163}$ by F. H. Emery on August 12, 1930.

York County, Armour heights, Toronto-Nest with five young was found on June 11, 1937, by D. S. Miller. The young were photographed and banded and the nest was secured for R.O.M.Z. after the young vacated (June 22).

\section{VESPER SPARROW POOECETES GRAMINEUS}

The Vesper Sparrow is a common breeding bird of Ontario, occurring from our southern border ${ }^{22}$ north to Southern Kenora District and Moose Factory ${ }^{31}$. Possible due to the scarcity of suitable habitat, it is relatively scarce in most of northern Ontario, but its range probably extends westward to Lake of the Woods ${ }^{29}$ where (at Indian bay, Manitoba), W. Rowan found a pair spending the summer of 1920. It breeds also in Lake of the Woods County, Minnesota ${ }^{176}$.

Our race is considered to be gramineus gramineus.

Cochrane District, Moose Factory-S. Waller took a nest with eggs on June 16, 1930.

Frontenac County - Set of five eggs was taken at Portsmouth on May 15, 1896, by E. Beaupre and set of three eggs in R.O.M.Z. was taken at Simcoe island 
by C. K. Clarke on July 17, 1897, as well as set of one egg plus egg of Cowbird taken on May 16, 1898, at Portsmouth by E. Beaupre.

Ilastings County - Set of three eggs taken near Bannockburn on May 30, 1921, by W. H. Lunn is in R.O.M.Z. E. W. Calvert found a nest with four eggs on May 24, 1927, at Stirling.

Huron County, West Wawanosh township - Set of three eggs was taken on July 16,1935 , and a set of four eggs on July 21, 1935, according to R. Smyth.

Kenora District, Wabigoon-Nest with four eggs was found on June 21, 1937, by T. M. Shortt,

Lincoln County, Merritton-Nest with four eggs was found on July 15, 1934, by G. J. Clout.

Renfrew County - Set of three eggs was found at Petawawa on May 28, 1916, by P. Harrington, and young just out of nest were seen at Cobden on June 11, 1925 , by E. W. Calvert.

Sudbury District, Chapleau-Nest with four young was found on June 3, 1937, by Martha Baillie.

Thunder Bay District-Set of four eggs was taken at Port Arthur on June 11, 1927 , by L. S. Dear. R. D. Ussher found a nest with young on July 3, 1924, near Jellicoe.

York County-Parent with two young was seen at King on July 27, 1934, by R. D. Ussher. At Toronto, J. A. Edwards took a set of three eggs on May 9,1911 , and R. D. Ussher found a nest with three eggs at King on July 23, 1935 (young hatched August 5).

\section{LARK SPARROW CHONDESTES GRAMMACUS}

The Lark Sparrow is a rare and irregular breeding summer resident of extreme southern Ontario ${ }^{22},{ }^{146}$ south and west of Hastings County (one male identified by R. C. Brett at Trenton on May 29, 1891).

Most of the nesting instances were during the years prior to 1900 , but J. F. Calvert found a nest with four eggs ${ }^{135}$ on May 24, 1930 at Walsingham, Norfolk County (also see below). Southern Algoma District $^{12}$ (one seen at Sault Ste. Marie in September, 1880, by W. E. Saunders) seemed to mark its northern limit of occurrence until one was collected at Chapleau, northern Sudbury District, on June 16, 1937, by P. Harrington.

Our race is grammacus grammacus, presumably.

Essex County, Point Pelee-Young just out of the nest, in N.M.C. was taken on June 22, 1913, by P. A. Taverner.

Kent County, Fargo-Breeds, according to W. E. Saunders, who has a specimen taken on June $6,1901$.

Norfolk County, Walsingham-Nest with four young was seen on June 1, 1930 (see above, and on June 16,1935, by W. E. Saunders. The latter nest, on the 5th concession, Walsingham township, was secured for R.O.M.Z. on June 23, 1935, by E. H. McKone.

York County, High Park, Toronto-P. Harrington has a set of three eggs plus Cowbird egg taken on July 1, 1898, by E. V. Rippon, and a set of three eggs in R.O.M.Z. was secured by J. L. Jackson on May 31, 1892. 


\section{SLATE-COLOURED JUNCO JUNCO HYEMALIS}

The Junco is a rather common ${ }^{104}$ summer resident of the whole of Ontario ${ }^{9},{ }^{12},{ }^{22},{ }^{29}$, nesting everywhere excepting in the extreme southern counties.

The form here is hyemalis hyemalis.

Algoma District, Mississagi Forest reserve-Nest with three eggs was found on June 6,1923 , by R. D. Ussher.

Cochrane District-At Bank's lake, Fenton township, near Kapuskasing, R. D. Usssher found a nest with three eggs, as well as one young just hatched on July 14, 1925. A nest and four eggs in R.O.M.Z. was taken on June 16, 1930, by S. Waller, at Moose Factory, and at Timmins Mrs. G. Roach found a nest with young in June, 1936.

Hastings County, Bird creek-Nest with five eggs in R.O.M.Z. was taken on June 21, 1935, by C. E. Hope.

Kenora District, Kenora-Nest with three young was found on June 14 and nest with two eggs and one young on August 6, 1931, by L. Paterson.

Muskoka District-At Burndick, Severn Falls, H. Zavitz took a set of five eggs (in R.O.M.Z.) in 1917 and at Robinsdale, A. W. Needler found a nest with three eggs on May 27, 1923; it contained three young on June 2nd. Sets of five and four eggs in R.O.M.Z. were taken at Port Sydney by A. Kay on May 4, 1885, and June 28, 1890, respectively:

Parry Sound District-Set of six eggs was taken on June 4, 1894, by J. H. Fleming at Emsdale. At Lynx lake, Kearney, H. B. Haugh took a nest with four eggs (in R.O.M.Z.) on June 16, 1920, and at Sundridge J. M. Speirs saw young birds in July, 1931. At Frank's bay, Lake Nipissing, C. H. D. Clarke found a nest with four eggs on June 1, 1932.

Sudbury District, Sylvanite lake, near Chapleat-Seen with young in August, 1934, by R. D. Black.

Temiskaming District, North Cobalt-Set of two eggs was taken on May 27, 1926, by L. S. Dear.

Thunder Bay District, Port Arthur-Set of five eggs was taken on May 27, 1926, by L. S. Dear.

York County-Adults were seen feeding young at King on July 17, 1934, by R. D. Ussher. At Toronto, J. L. Jackson took set of four eggs on June 13, 1890, and set of three eggs on July 7, 1887, both of which are in R.O.M.Z. At Rosedale, J. H. Samuel discovered a nest with four or five young on May 14, 1894.

\section{CHIPPING SPARROW SPIZELLA PASSERINA}

The Chipping Sparrow is one of the commonest breeding birds of Ontario south of the Albany River and the southern end of James bay ${ }^{12}$. It probably ranges westward to Lake of the Woods, as W. Rowan found it to be generally distributed in 1920 at Indian bay, Manitoba, just beyond the Ontario border. Also, it breeds in Minnesota ${ }^{176}$, adjacent to extreme western Ontario, and a nest with four young was found on June 15,1927 , by R. D. Ussher at Family lake (Lat. $52^{\circ}$ N.) on the Manitoba side of the Manitoba-Ontario boundary. 
The Ontario Chipping Sparrow is considered to be the eastern race, passerina passerina.

Carleton County, Ottawa-Nest containing two young and one egg (young left at our intrusion) was found by J. L. Baillie on July 5, 1935.

Cochrane District-S. Waller took a nest with four eggs (in R.O.M.Z.) on June 16, 1930, at Moose Factory and E. Dixon has eggs taken by A. V. Dukes at Lake Abitibi.

Essex County, Point Pelee-Nest and four eggs in R.O.M.Z. were taken on June 14, 1920, by L. L. Snyder.

Kenora District-At Kenora a nest with four eggs was found on July 1 and nest with three eggs on July 28,1931 , by L. S. Paterson. A nest with four young was found on June 25, 1935, by J. Satterly at Fry lake, Lake St. Joseph, Albany river, at Lat. $51^{\circ} 15^{\prime} \mathrm{N}$., between Long. $91^{\circ}-92^{\circ} \mathrm{W}$.

Muskoka District, Robinsdale-A nest found by A. W. Needler on June 4, 1923, with four eggs contained four young on the 19th.

Renfrew County, Petawawa-Set of four eggs was found in nest on May 26 and set of four eggs on June 27, 1916, by P. Harrington.

Simcoe County-At Barrie a set of four eggs was taken by H. P. Bingham on May 16, 1913, (in R.O.M.Z.) and at Wasaga beach P. Harrington found nest with three eggs plus two Cowbird's eggs on June 3, 1928.

Thunder Bay District-A set of four eggs was found at Port Arthur on June 5, 1914, by L. S. Dear and a nest with three eggs at Port Arthur on June 29, 1929 , by J. L. Baillie. R. D. Ussher found a pair feeding young on July 6 , 1924. near Lake Nipigon.

Welland County, Port Colborne-R. A. Smith found a nest with four eggs on July 7, 1935.

York County, Toronto-J. A. Edwards found a nest with three eggs on May 13, 1911, and at Forest Hill H. B. Haugh took a nest with four eggs on June 7, 1917 (in R.O.M.Z.).

\section{CLAY-COLOURED SPARROW SPIZELla PALlidA}

This western species occurs not uncommonly in summer at various places bordering Lake Superior ${ }^{95}$ and westward to the Manitoba boundary ${ }^{29}$, breeding at Port Arthur ${ }^{49},{ }^{98}$ and at Kenora, and possibly at most suitable places between Lake Superior and Lake of the Woods.

Its occurrence during different summers in Middlesex County ${ }^{22}$ and on one occasion each in Renfrew ${ }^{115}$, Huron (specimen taken at Meneset on June 8, 1931, by C. H. D. Clarke), Simcoe (one seen on June 10, 1935 , at Wasaga beach by O. E. Devitt and one in R.O.M.Z. secured at Hawkestone by H. B. Haugh on May 28, 1930) and York Counties (one seen on May 28, 1931, at Toronto by T. F. McIlwraith and others) indicates that it may nest rarely in the more southern parts of the province.

The form occurring in Ontario is pallida pallida.

Kenora District-Nested fairly commonly in 1932, according to L. Paterson at Kenora. At Wabigoon a colony was found nesting in June, 1937, by L. L. Snyder and T. M. Shortt. 


\section{FIELD SPARROW SPIZELLA PUSILlA}

The Field Sparrow is an uncommon and locally distributed summer resident of southern Ontario north to Muskoka District ${ }^{39}$, north Frontenac County ${ }^{12}$ and Ottawa ${ }^{23},{ }^{151}$ nesting throughout its range.

The form occurring here is pusilla pusilla.

Elgin County, Port Burwell-Nest with one egg plus Cowbird egg was found on June 7, 1925, by F. Starr.

Essex County-Nest with young was found on June 5, 1933, by us at Pelee island. At Point Pelee, W. E. Saunders collected a set of four eggs plus egg of Cowbird on May 13, 1905. At Harrow, W. E. Saunders took a set of three eggs on June 7, 1909.

Frontenac County, Kingston-Nest with four young was found on June 3, 1933, by L. L. Snyder and nest with three eggs was found on June 20,1905, by E. Beaupre.

Leeds County-At Junetown, a set of eggs was taken on May 14, 1901, by E. Beaupre. At Westport, L. L. Snyder located a nest with three young about August 1, 1934.

Lincoln County, St. Catharines-Nest with three eggs was found by J. G. Clout on June 16, 1936.

Norfolk County, Walsingham township-Nest and four eggs in R.O.M.Z. were obtained on May 29, 1933, by J. Edmonds.

Ontario County-A set of four eggs was found at Beaverton on May 30, 1913, by J.A. Edwards and H. V. McIntyre found a nest with four eggs at Whitby about 1912.

Peel County, Erindale-On June 5, 1937, a nest with four young was found by Marie Boissonneau.

Simcoe County, Wasaga beach-P. Harrington took a set of four eggs on June 7, 1923.

York County, Toronto-Nest with four eggs was found on May 17, 1916, and nest with three eggs plus egg of Cowbird on June 7, 1924, by P. Harrington.

\section{WHITE-CROWNED SPARROW ZONOTRICHIA LEUCOPHRYS}

Only bordering Hudson bay and northern James bay (north and west of the Albany river) has the White-crowned Sparrow been found as a breeding bird of Ontario, ${ }^{12},{ }^{21}$. There is no doubt that it is common in parts of that region, as it breeds abundantly at Churchill, Manitoba (just beyond the borders of Ontario) ${ }^{9}$. Severn river, on Hudson bay ${ }^{25}$ is its type locality.

Our race is considered to be the typical leucophrys leucophrys.

\section{WHITE-THROATED SPARROW ZONOTRICHIA ALBICOLLIS}

The White-throated Sparrow is one of our commonest and most characteristic summer residents, occurring throughout the province ${ }^{12},{ }^{29}$. There is little doubt that it breeds throughout Ontario, more rarely along the southern border. 
Algoma District, Gull lake, Townșhip 3C, Mississagi Forest reserve-R. D. Ussher found a nest with four eggs on July 4, 1923.

Cochrane District-A set of three eggs was found at Smoky Falls, north of Kapuskasing, on July 8,1933 , by R. V. Whelan, and near Kapuskasing R. D. Ussher found a nest with two or three young on August 4, 1925. At Moose Factory, S. Waller took a nest with four eggs on June 12, 1930 (in R.O.M.Z.).

Durham County, Hampton-Nest with four eggs was found on June 22, 1927, by A. E. Allin.

Frontenac County, Portsmouth-Set of four eggs plus Cowbird's egg was taken on June 20, 1921, by E. Beaupre.

Hastings County, Madoc-Set of five eggs in R.O.M.Z. was taken on June 3, 1925 , by E. Beaupre.

Kenora District, Ontario side of Indian bay, Lake of the Woods-Nested abundantly in 1920 , according to letter from W. Rowan.

Nipissing District-An occupied nest was found on July 18, 1926, by A. F. Coventry four miles south of Bear island in Temagami, and W. E. Saunders has a set of four eggs obtained by him on August 5, 1908, at Cache lake, Algonquin Park.

Parry Sound District-At Emsdale a set of four eggs in R.O.M.Z. was collected on May 28, 1893, by J. H. Fleming. At Frank's bay, Lake Nipissing, a nest with five eggs was located on June 4,1933 , by E. S. Pentland.

Thunder Bay District, Port Arthur-Set of five eggs was found on June 13, 1924, by L. S. Dear.

York County-Nest with four eggs was found on May 24, 1931, by us at Sharon, and at King R. D. Ussher found a nest with three eggs on August 4, 1934.

\section{LINCOLN'S SPARROW MELOSPIZA LINCOLNI}

This species is of rather local distribution, breeding from York County ${ }^{60}$ to beyond the transcontinental line of the Canadian National Railway ${ }^{19},{ }^{31},{ }^{90}$ (Smoky Falls) and probably northward to Hudson's Bay ${ }^{12}$, commonly in many localities in the more northern parts of the province. At Ingolf and Wabigoon, southern Kenora District, it was found uncommonly during June, 1937, by R.O.M.Z. field-party, L. L. Snyder and T. M. Shortt. It may breed locally south to Lake Erie, as G. W. North found it in the summer of 1935 at Wainfleet Marsh, Welland County. Six pairs were seen there on June 30, and July 5, 1936, by Mary E. Brown and W. Brockner, according to the "Prothonotary", July, 1936.

Our form is the typical race, lincolni lincolni.

Algoma District, Amyot-Young bird, in R.O.M.Z. just out of nest, was taken by C. E. Hope on June 29, 1936.

Cochrane District-At Kapuskasing, a juvenile in N.M.C. was secured on June 25, 1919, by C. E. Johnson. It was scarcely able to fly. At Smoky Falls, a young bird was collected on July 27,1935 , by R. V. Whelan (in R.O.M.Z.)

Sudbury District-Biscotasing-Adult was seen feeding young on June 19, 1937, by F. Starr and P. Harrington.

Thunder Bay District, Whitefish lake-Nest with four eggs was collected on June 13, 1935, by P. Harrington. 


\section{SWAMP SPARROW MELOSPIZA GEORGIANA}

In suitable swampy localities, this species is a common breeding summer resident throughout the whole of Ontario ${ }^{12},{ }^{21},{ }^{29}$ west to Thunder Bay District and probably to the Manitoba border (plentiful in 1920 on the Ontario side of Indian bay, Lake of the Woods, according to letter from W. Rowan).

Essex County, Point Pelee-Nest with three eggs was found on June 6, 1932, by H. H. Southam and J. L. Baillie.

Frontenac County, Kingston-Set of four eggs in R.O.M.Z. was taken on May 21, 1897 , by E. Beaupre.

Hastings County, Stirling-Nest with three eggs was found on May 30, 1926, by E. W. Calvert.

Lincoln County, Niagara-on-the-Lake--W. P. Young took a set of four eggs on June 23, 1926.

Ontario County-At Simcoe Point, Pickering, a nest with three eggs was found on June 6,1935 , by R. A. Smith, and at Frenchman's bay C. E. Hope found six nests with four eggs in each on June 9, 1929 (one set in R.O.M.Z.).

Parry Sound District, Sundridge - Young were seen in July, 1931, by J. M. Speirs.

Simcoe County-Set of five eggs, plus Cowbird egg, was found by us on June 4, 1929, at Marl lake. At Orr lake, F. Starr saw a nest with four young on June 7, 1929.

Sudbury District, Bigwood-Young in R.O.M.Z. was collected on July 16, 1937, by J. L. Baillie.

Thunder Bay District, Whitefish lake-Nest with four eggs was found by us on June 8, 1935.

York County-Nest with four eggs, plus Cowbird's egg, was found by us on May 24, 1931, at Sharon and a set of four eggs from Toronto, in R.O.M.Z., was secured by J. L. Jackson on June 26, 1889.

\section{SONG SPARROW MELOSPIZA MELODIA}

The Song Sparrow is a very common summer resident of Ontario north to northern James bay ${ }^{12}$ and west to Lake of the Woods ${ }^{29},{ }^{176}$ and probably northward, as D. R. Derry found them commonly during the summer of 1930 between Lat. $53^{\circ}$ and $54^{\circ} \mathrm{N}$. on the Manitoba boundary, and a nest with five eggs was found on June 10, 1927 at Family lake (Lat. $52^{\circ} \mathrm{N}$.) on the Manitoba side of the boundary by R. D. Ussher. It breeds everywhere throughout its range.

The typical race here is said to be melodia melodia but melodia juddi replaces it in western Ontario ${ }^{19}$ and there is every possibility that melodia beata occurs in southwestern Ontario as a nesting form.

Algoma District, Mississagi Forest Reserve-A nest with five eggs was found on June 9,1923 , by R. D. Ussher.

Cochrane District, Kapuskasing-Pair raised brood in early July, 1919, according to P. A. Taverner. 
Frontenac County, Portsmouth-Set of six eggs in R.O.M.Z. was taken on May 4, 1897, by E. Beaupre.

Kenora District-At Ontario side of Indian bay, Lake of the Woods, it bred very abundantly in 1920, according to letter from W. Rowan, and a nest with

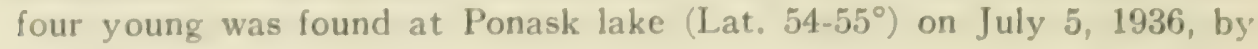
Dr. J. Satterly.

Lincoln County, near St. Catharines-Nest with five eggs was found by G. J. Clout on May 16, 1935, and nest with four young on June 20, 1936.

Muskoka District-Nest and three eggs in R.O.M.Z. were taken on July 15, 1919, by L. L. Snyder at Port Sydney. In early August, 1932, half-grown young were seen by T. F. McIlwraith near Fox Point, Lake of Bays. At Robinsdale, A. W. Needler found a nest with five eggs on May 30, 1923; it contained five young on June 5 th. At Huntsville, a nest with five eggs was seen on May 24, 1932, by F. Banfield.

Nipissing District-Nest with eggs was found on July 25, 1928, by A. F. Coventry at Temagami. At Green lake, Algonquin Park, a nest with four young was found by S. L. Thompson on July 14, 1910.

Simcoe County-A nest with five eggs was seen at Barrie by H. P. Bingham on May 11, 1915, and on June 3, 1929, we found a nest with five young at Wasaga beach, where P. Harrington found a nest with three eggs on July 27, 1914.

Thunder Bay District - Set of five eggs was taken on June 5, 1935, by F. Starr at Whitefish lake; the nest is in R.O.M.Z. At Port Arthur, L. S. Dear took a set of five eggs on May 30, 1911.

York County, Toronto-A nest with two eggs plus Cowbird egg was seen by R. V. Lindsay on April 26, 1925, and a nest with six eggs was seen by J. L. Baillie at Moore park on May 6, 1923. A set of four eggs in R.O.M.Z. was secured by J. L. Jackson on June 18, 1891. At King, on August 31, 1935, R. D. Ussher found a nest still containing three young.

\section{LITERATURE CITED}

${ }^{2}$ Statistical Account of Upper Canada, Vol. 1, 1822, pp. 171-5.

${ }^{2}$ Canadian Naturalist and Geologist, Vol. 4, 1859, pp. 231-3.

${ }^{3}$ Journ. and Proc. Hamilton Assoc., Vol. 1, 1885-6, pp. 45-324.

${ }^{4}$ Published by the authority of N. Awrey, M.P.P., Toronto, pp. 1-27.

${ }^{5}$ Thomas McIlwraith, The Birds of Ontario, 1894, pp. 1-426.

${ }^{6}$ Department of Education, Ontario, 1900.

'Department of Education, Ontario, 190.5.

${ }^{8}$ M. Y. Williams, Can. Field-Nat., Vol. 34, 1920, pp. 121-5.

${ }^{9}$ Percy A. Taverner and George Miksch Sutton, Annals Carnegie Museum, Vol. 23, 1934, pp. 1-83.

${ }^{10}$ W. E. Saunders, Can. Field-Nat., Vol. 36, 1922, p. 137.

${ }^{11}$ Nap. A. Comeau, Ann. Rep. Dept. Naval Service, Canada, 1913-4.

${ }^{12} \mathrm{John}$ and James M. Macoun, Cat. of Can. Birds, 1909.

${ }^{13}$ C. W. G. Eifrig, Ottawa Nat., Vol. 24, 1910-11.

${ }^{14} \mathrm{G}$. E. Atkinson, Biol. Review of Ont., Vol. 1, 1894, pp. 94-101.

${ }^{15}$ L. L. Snyder and J. L. Baillie, Can. Field-Nat., Vol. 37, 1923, pp. 91-3.

${ }^{16}$ Alvan H. Alberger, Orn. and Oologist, Vol. 15, 1890, pp 87-8. 
${ }^{17}$ M. J. Magee, Can. Field-Nat., Vol. 37, 1923, pp. 145-6.

${ }^{18} \mathrm{Wm}$. G. Fargo and Josselyn Van Tyne, Can. Field-Nat., Vol. 41, 1927, pp. 7-9.

${ }^{19}$ L. L. Snyder, Trans. Royal Can. Inst., Vol. 16, 1928, pp. 251.-77.

${ }^{20}$ Harrison F. Lewis, The Natural History of the Double-crested Cormorant, 1929, p. 6.

${ }^{21}$ Edward A. Preble, N. A. Fauna, no. 22, 1902.

${ }^{22}$ W. E. Saunders and E. M. S. Dale, Trans. Royal Can. Inst., Vol. 19, 1933, pp. 161-249.

${ }^{23}$ Hoyes Lloyd, Can. Field-Nat., Vols. 37 and 38, 1923 and 1924.

${ }^{24}$ P. A. Taverner, Ottawa Nat., Vol. 32, 1918, p. 97.

${ }^{25}$ J. R. Forster, Philosophical Trans., Vol. 62, 1772, pp. 382-433 (Willughby Society reprint, 1882).

${ }^{26}$ Arthur Cleveland Bent, Bull. I35, U. S. Nat. Mus., 1926.

${ }^{27}$ L. L. Snyder, Trans. Royal Can. Inst., Vol. 28, 1931, pp. 139-227.

${ }^{28} \mathrm{John}$ Alfred Morden, Can. Sportsman and Nat., Vol. 3, 1883.

${ }^{29}$ William Rowan, Auk, Vol. 39, 1922, pp. 224-32.

${ }^{30}$ William Brewster, $A u k$, Vol. 19, 1902, p. 187.

${ }^{31}$ L. L. Snyder, Univ. of Toronto. Studies, Biol. Series no. 32, 1928, pp. 17-34.

${ }^{32}$ Arthur Cleveland Bent, Bull. I3o, U. S. Nat. Mus., 1925.

${ }^{33}$ Ann. Report, Ont. Agric. College, 1903-4.

${ }^{34}$ C. W. Nash, Vertebrates of Ont., 1908.

${ }^{35}$ John Townson, Can. Field-Nat., Vol. 44, 1930, p. 167.

${ }^{36}$ Wells W. Cooke, U. S. Dept. Agric., Biol. Surv. Bull., No. 26, 1906.

${ }^{37}$ M. Y. Williams, Ottawa Nat., Vol. 32, 1918, p. 37.

${ }^{38} \mathrm{~J}$. H. Fleming, $A u k$, Vol. 20, 1903, p. 66.

${ }^{39}$ James H. Fleming, $A u k$, Vol. 18, 1901, pp. 33-45.

${ }^{40} \mathrm{~J}$. Dewey Soper, $A u k$, Vol. 40, 1923, pp. 489-513.

${ }^{41}$ A. H. Wright and S. E. R. Simpson, Can. Field-Nat., Vol. 34, 1920, pp. 161-6.

${ }^{42}$ Robert Vince Lindsay, Can. Field-Nat., Vol. 48, 1934, pp. 11-14.

${ }^{43}$ James H. Fleming, Auk, Vol. 23, 1906, pp. 437-53 and Vol. 24, 1907, pp. 71-89.

${ }^{44}$ Ernest E. Thompson, Proc. U. S. Nat. Mus., Vol. 13, 1890, pp. 457-643.

${ }^{45}$ George T. McKeough, Can. Field-Nat., Vol. 38, 1924, p. 188.

${ }^{46}$ Rudolph Martin Anderson, Proc. Fifth Pacific Science Congress, 1934, p. 776.

${ }^{47}$ W. E. Saunders, Ottawa Nat., Vol. 23, 1909, pp. 132-3.

${ }^{48}$ Hoyes Lloyd, Can. Field-Nat., Vol. 42, 1928, pp. 143-4.

${ }^{49}$ Walter Bradford Barrows, Special Bull. Dept. Zoology and Physiology, Michigan Agricultural College, 1912.

${ }^{50}$ J. A. Morden and W. E. Saunders, Can. Sportsman and Nat., Vol. 2, 1882.

${ }^{51}$ W. J. Brown, Ottawa Nat., Vol. 22, 1908, p. 163.

${ }^{62}$ C. K. Clarke, $A u k$, Vol. 18, 1901, p. 112.

${ }^{53}$ G. A. MacCallum, Ottawa Nat., Vol. 15, 1901, pp. 127-8 and Vol. 21, 1907, p. 38.

${ }^{54}$ W. E. Saunders, Can. Field-Nat., Vol. 33, 1919, pp. 55-7.

${ }^{65}$ R. Owen Merriman, Can. Field-Nat., Vol. 46, 1932, p. 22.

${ }^{56}$ Rev. C. J. Young, Ottawa Nat., Vol. 14, 1900, pp. 69-71.

${ }^{57}$ W. E. Saunders, Ottawa Nat., Vol. 30, 1916, pp. 39-40.

${ }^{58} \mathrm{~J}$. H. Fleming, $A u k$, Vol. 30, 1913, pp. 225-8.

${ }^{59}$ P. A. Taverner, $A u k$, Vol. 29, 1912, p. 397.

${ }^{60}$ L. L. Snyder, Trans. Royal Can. Inst., Vol. 17, 1930, pp. 183-202.

${ }^{61}$ Edwin Beaupre, Ottawa Nat., Vol. 16, 1902, p. 103.

${ }^{62}$ J. Dewey Soper, Can. Field-Nat., Vol. 37, 1923, pp. 13-15.

${ }^{63}$ Gerrit S. Miller, Jr., Proc. Boston Soc. Nat. Hist., Vol. 28, 1897, pp. 1-44.

${ }^{64}$ Stuart L. Thompson, Can. Field-Nat., Vol. 36, 1922, pp. 161-8. 
${ }^{6 s}$ Howard Skales, Ont. Nat. Sc, Bull., No. 2, 1906, p. 23.

${ }^{6}$ W. E. Saunders, $A u k$, Vol. 27, 1910, pp. 209-10.

${ }^{67}$ Rev. C. J. Young, Ottawa Nat., Vol. 18, 1904, pp. 139-40.

${ }^{68}$ William Swainson and John Richardson, Fauna Boreali-Americana, Part Second, 1831.

${ }^{69} \mathrm{~J}$. H. Fleming, $A u k$, Vol. 19, 1902, pp. 403-4.

${ }^{70}$ Charles Macnamara, Ottawa Nat., Vol. 31, 1917, pp. 49-54.

${ }^{7}$ Hoyes Lloyd, Auk, Vol. 34, 1917, pp. 457-460.

${ }^{72}$ Robert V. Lindsay, Can. Field-Nat., Vol. 45, 1931, pp. 205-6.

${ }^{73}$ Robert Virtue, Can. Field-Nat., Vol. 43, 1929, p. 110.

${ }^{74}$ W. E. Saunders, Can. Field-Nat., Vol. 37, 1923, pp. 116-7.

${ }^{75}$ M. G. Gould, Bird-Lore, Vol. 24, 1922, pp. 96-7.

${ }^{76}$ Allan Brooks, Ont. Nat. Sc. Bull., no. 2, 1906, pp. 6-10.

${ }^{77} \mathrm{P}$. A. Taverner, Bull. 4I, Victoria Memorial Mus., 1926.

${ }^{78}$ J. Dewey Soper, Can. Field-Nat., Vol. 34, 1920, pp. 72-3.

${ }^{79}$ Jas. L. Baillie, Jr., Can. Field-Nat., Vol. 42, 1928, p. 177.

${ }^{80}$ Harrison F. Lewis, $A u k$, Vol. 49, 1932, p. 225.

${ }^{81}$ Robert T. Morris, Rod and Gun and Motor Sports in Can., Vol. 9, 1907, pp. 186-7.

${ }^{82}$ Louis Agassiz, Lake Superior, its Physical Character, Vegetation and Animals, 1850.

${ }^{83} \mathrm{~J}$. A. Allen, Bull. Nuttall Orn. Club, Vol. 4, 1879, p. 26.

${ }^{84}$ Sixth Ann. Rept. of the Game and Fisheries Dept., Ontario, 1913, p. 13.

${ }^{85}$ Eighth Ann. Rept. of the Game and Fisheries Dept., Ontario, 1915, p. 8.

${ }^{86} \mathrm{G}$. Eifrig, $A u k$, Vol. 26, 1909, pp. 58-9; pp. 432-3.

${ }^{87}$ Paul Harrington, Can. Field-Nat., Vol. 36, 1922, pp. 176-7.

${ }^{88}$ W. E. Saunders, Ottawa Nat., Vol. 25, 1912, pp. 152-3.

${ }^{89}$ Jas. L. Baillie, Jr., Can. Field-Nat., Vol. 39, 1925, p. 194.

${ }_{90}$ M. J. Magee, Can. Field-Nat., Vol. 36, 1922, p. 153.

${ }^{91}$ R. J. Rutter, Can. Field-Nat., Vol. 43, 1929, p. 188.

${ }^{92}$ W. H. A. Preece, Can. Field-Nat., Vol. 37, 1923, p. 169.

${ }^{93}$ J. H. Garnier, Can. Sportsman and Nat., Vol. 2, 1882, pp. 111-2.

${ }^{94}$ M. Y. Williams, Can. Field-Nat., Vol. 35, 1921, pp. 94-7.

${ }^{95}$ W. H. A. Preece, Can. Field-Nat., Vol. 38, 1924, pp.9-10.

${ }^{96}$ Hubert Richardson, Can. Field-Nat., Vol. 47, 1933, p. 58.

${ }^{97}$ W. E. Saunders, Ottawa Nat., Vol. 22, 1908, pp. 115-7.

${ }^{98}$ Walter Kaelz, Can. Field-Nat., Vol., 37, 1923, p. 118.

${ }^{99}$ C. E. Johnson, Can Field-Nat., Vol. 36, 1922, p. 60.

${ }^{100}$ Ralph E. DeLury, Can. Field-Nat., Vol. 36, 1922, p. 120.

${ }^{101}$ Lois R. Kingston, Can. Field-Nat., Vol. 38, 1924, p. 18.

${ }^{102}$ Paul Harrington, Can. Field-Nat., Vol. 38, 1924, p. 58.

${ }^{103}$ Hoyes Lloyd, Can. Field-Nat., Vol. 39, 1925, p. 17.

${ }^{104}$ H. W. Fairbairn, Can. Field-Nat., Vol. 41, 1927, pp. 150-2.

${ }^{105}$ Official Canadian Record of Bird-Banding Returns, Can. Field-Nat., Vol. 41, 1927, p. 169.

${ }^{106}$ Manly F. Miner, Can. Field-Nat., Vol. 43, 1929, p. 20.

${ }^{107}$ Robt. V. Lindsay, Can. Field Nat., Vol. 43, 1929, p. 164.

${ }^{108}$ W. E. Saunders, Can. Field-Nat., Vol. 43, 1929, p. 190.

${ }^{109}$ William G. Fargo and Milton B. Trautman, Can. Field-Nat., Vol. 44, 1930, pp. 31-3.

${ }^{110}$ H. W. Fairbairn, Can. Field-Nat., Vol. 44, 1930, pp. 88-91.

${ }^{111}$ Bertram W. Cartwright, Can. Field-Nat., Vol. 45, 1931, p. 184.

${ }^{112}$ Anna E. MacLoghlin, Can Field-Nat., Vol. 46, 1932, p. 68.

${ }^{113}$ Hoyes Lloyd, Can Field-Nat., Vol. 46, 1932, pp. 125-6, 162-6. 
${ }^{114}$ L. T. S. Norris-Elye, Can. Field-Nat., Vol. 46, 1932, p. 142.

${ }^{115}$ Hoyes Lloyd, Can. Field-Nat., Vol. 47, 1933, p. 36.

${ }^{116}$ A. A. Wood, Can. Field-Nat., Vol. 47, 1933, p. 143.

${ }^{117}$ C. E. Johnson, Can. Field-Nat., Vol. 48, 1934, p. 82.

${ }^{118}$ William C. Baker, Auk, Vol. 49, 1932, pp. 100-1.

${ }^{119}$ Harrison F. Lewis, $A u k$, Vol. 49, 1932, p. 225.

${ }^{120}$ Edward Howe Forbush, Birds of Massachusetts, Vol. 1, 1925.

${ }^{121}$ Robert L. Baird, Bird-Lore, Vol. 32, 1930, pp. 434-5.

${ }^{122}$ W. E. Saunders, Ottawa Nat., Vol. 12, 1898, p. 178.

${ }^{123}$ Ninth Ann. Rept. of the Game and Fisheries Dept. (Ontario), 1916, p. 23.

${ }^{124}$ Sixteenth Ann. Rept. of the Game and Fisheries Dept. (Ontario), 1923, p. 9.

${ }^{125}$ Twentieth Ann. Rept. of the Game and Fisheries Dept. (Ontario), 1927, p. 6.

${ }^{126}$ Twenty-third Ann. Rept. of the Game and Fisheries Dept. (Ontario), 1930, p. 7.

${ }^{127}$ Rev. J. Hibbert Langille, Our Birds in their Haunts, 1884.

${ }^{128}$ F. L. Farley, Oologist, Vol. 8, 1891, pp. 81-7.

${ }^{129}$ B. H. Swales, Oologist, Vol. 8, 1891, pp. 246-7.

${ }^{130}$ Edward Reinecke, Oologist, Vol. 12, 1895, p. 45.

${ }^{131}$ Norman Haultain, Oologist, Vol. 30, 1913, p. 100.

${ }^{132}$ Harry C. Oberholser, Bird-Lore, Vol. 20, 1918, pp. 345-9.

${ }^{133}$ A. D. Sutherland, Oologist, Vol. 46, 1929, pp. 80-1.

${ }^{134}$ Distribution Maps, U. S. Biol. Surv., April, 1934.

${ }^{135}$ E. M. S. Dale, Can. Field-Nat., Vol. 45, 1931, p. 21.

${ }^{136}$ H. Moshier, Rod E Gun in Can., Vol. 12, 1911, p. 1048.

${ }^{137}$ John C. Phillips, A Natural History of the Ducks, Vol. 2, 1923.

138John C. Phillips, A Natural History of the Ducks, Vol. 3, 1925.

${ }^{139}$ John C. Phillips, A Natural History of the Ducks, Vol. 4, 1926.

${ }^{140}$ A. G. Kingston, Ottawa Nat., Vol. 9, 1895, pp. 92-3.

${ }^{141}$ Lewis M. Terrill, Ottawa Nat., Vol. 17, 1904, p. 171.

${ }^{142}$ A. B. Klugh, Ottawa Nat., Vol. 19, 1905, p. 87.

${ }^{143}$ Thomas McIlwraith, Journ. and Proc. Hamilton Assoc. Vol. 1, 1886.

${ }^{144}$ R. G. Price, Ottawa Nat., Vol. 24, 1910, p. 55.

${ }^{145}$ W. E. Saunders, Ottawa Nat., Vol. 26, 1913, p. 130.

${ }^{146}$ P. A. Taverner, Ottawa Nat., Vol. 28, 1914, p. 99.

${ }^{147}$ W. J. Wintemberg, Can. Field-Nat., Vol. 33, 1919, p. 68.

${ }^{148}$ W. E. Saunders, Auk, Vol. 2, 1885, p. 307.

${ }^{149}$ Ralph E. and Justin S. DeLury, Can. Field-Nat., Vol. 36, 1922, p. 137.

${ }^{150}$ Ralph E. DeLury, Can. Field-Nat., Vol. 38, 1924, pp. 21-4.

${ }^{151}$ Hoyes Lloyd, Can Field-Nat., Vol. 38, 1924, p. 180.

${ }^{152}$ R. O. Merriman, Can. Field-Nat., Vol. 41, 1927, p. 140.

${ }^{153}$ Margaret K. H. Mitchell, Can. Field-Nat., Vol. 43, 1929, pp. 147-52.

${ }^{154}$ J. A. Munro, Can. Field-Nat., Vol. 44, 1930, p. 88.

${ }^{155}$ Jas. L. Baillie, Jr., Can. Field-Nat., Vol. 45, 1931, p. 180.

${ }^{156}$ P. A. Taverner and B. H. Swales, Wilson Bull., Vol. 14, 1907 and Vol. 15, 1908.

${ }^{157}$ W. E. Saunders, Wilson Bull., Vol. 14, 1907, p. 74.

${ }^{158}$ W. H. McNairn, Oologist, Vol. 8, 1891, p. 235.

${ }^{169}$ Ottamar Reinecke, Oologist, Vol. 27, 1910, p. 88.

${ }^{160}$ H. P. Bingham, Oologist, Vol. 41, 1924, p. 44.

${ }^{161}$ H. P. Bingham, Oologist, Vol. 43, 1926, p. 108.

${ }^{162}$ Harrison F. Lewis, Univ. of Tor. Studies, Biol. Series, no. 30, 1927.

${ }^{163}$ E. M. S. Dale, Can. Field-Nat., Vol. 46, 1932, p. 107. 
${ }_{184}$ A. C. Lloyd, Can. Field-Nat., Vol, 48, 1934, p. 82.

${ }^{185}$ Charles Macnamara, Can. Field-Nal., Vol. 49, 193j, pp. $31-2$.

${ }^{166}$ O. E. Devitt, Can. Field-Nat., Vol. 49, 1935, p. 76.

${ }^{167} \mathrm{~J}$. Murray Speirs, Can. Field-Nat., Vol. 49, 1935, p. 123.

${ }^{108}$ W. J. Wintemberg, Can. Field-Nat., Vol. 49, 1935, p. 125.

${ }^{180}$ Margaret H. Mitchell, Contrib. No. 7, Royal Ont. Mus. of Zool., 1935, p. 62.

${ }^{170} \mathrm{~J}$ ohn Macoun, Cat. of Can. Birds, Part 2, 1903.

${ }^{171}$ Edward Howe Forbush, Birds of Massachusetts, Vol. 2, 1927.

172 John Macoun, Cat. of Can. Birds, Part 1, 1900.

173 John Macoun, Cat of Can. Birds, Part 3, 1904.

${ }^{174}$ L. M. Turner, Proc. U. S. Nat. Mus., 1885, p. 245.

${ }^{176}$ W. E. Saunders, $A u k$, Vol. 34, 1917, pp. 334-5.

${ }^{176}$ Thomas S. Roberts, Birds of Minnesota, 1932.

${ }^{177}$ W. E. Saunders, Saturday Night, Mar. 26, 1927.

${ }^{178}$ Sir John Richardson, Arctic Searching Exped., 1852, p. 396.

${ }^{179}$ L. L. Snyder, Univ. of Toronto Studies, Biol. Series, no. 40, 1935.

${ }_{180}$ P. A. Taverner, Bull. 72, Nat. Mus. of Can., 1934.

${ }^{181}$ W. E. Saunders, $A u k$, Vol. 4, 1887, p. 247.

${ }^{182}$ Francis J. A. Morris, Can. Ent., Vol. 53, 1921, pp. 219-44.

183" "Nipissing", Forest and Stream, Vol. 37, 1891, p. 310.

${ }^{184}$ Robert Bell, Can. Nat. and Geol., Vol. 6, 1861, pp. 274-5.

${ }^{185}$ Rod $\mathcal{E}^{\circ}$ Gun in Can., Vol. 12, 1910, pp. 250-64.

${ }^{186}$ James E. Orr, Rod \& Gun in Can., Vol. 11, 1909, pp. 524-6.

${ }^{187}$ W. L. Scott, $A u k$, Vol. 2, 1885, p. 110.

${ }^{188}$ Rev. C. W. G. Eifrig, $A u k$, Vol. 23, 1906, p. 316.

${ }^{189}$ Bayard H. Christy, Cardinal, Vol. 2, 1927, pp. 46-8.

${ }^{100}$ William Rowan, Ecology, Vol. 3, 1922, p. 256.

${ }^{191}$ Rept. of E. B. Borron, Hudson's Bay, 1884, p. 35.

${ }^{192}$ W. E. Saunders, $A u k$, Vol. 26, 1909, p. 430.

${ }^{193}$ Andrew Murray, Edin. New Phil. Journ., Apr. 1859, pp. 598-608.

${ }^{194}$ A. B. Klugh, Ont. Nat. Sc. Bull., no. 1, 1905, p. 10.

${ }^{196}$ A. B. Klugh, $A u k$, Vol. 23, 1906, p. 105.

${ }^{196}$ William J. Garnett, Can. Field-Nat., Vol. 43, 1929, p. 84.

${ }^{197}$ C. L. Broley, Can. Field-Nat., Vol. 43, 1929, p. 21.

${ }^{198} \mathrm{~J}$. H. Fleming and Hoyes Lloyd, $A u k$, Vol. 37, 1920, pp. 437-8.

${ }^{199}$ A. Kay, Biol. Review of Ont., Vol. 1, 1894, pp. 66-7.

${ }^{200}$ A. B. Klugh, Ont. Nat. Sc. Bull., no. 2, 1906, pp. 17-8.

${ }^{201}$ W. E. Saunders, Bird-Lore, Vol. 37, 1935, p. 326.

${ }^{202}$ W. R. Ogilvie-Grant, Cat. of the Coll. of Birds' Eggs in the British Museum (Nat. Hist.) Vol. 5, 1912.

${ }^{203}$ G. Eifrig, Wilson Bull., Vol. 25, 1913, p. 144.

${ }^{204}$ Frank L. Burns, Wilson Bull., Vol. 18, 1911, p. 172.

${ }^{205}$ W. E. Saunders, Wilson Bull., Vol. 21, 1909, p. 153.

${ }^{206}$ Lawrence E. Hicks, $A u k$, Vol. 51, 1934, p. 385.

${ }^{207}$ Lawrence E. Hicks, Ohio Biol. Surv., Vol. 6, 1935.

${ }^{208}$ W. E. Clyde Todd, Annals Carnegie Mus., Vol. 2, 1904, pp. 481-596.

${ }^{209}$ Harold D. Mitchell, Hobbies, Vol. 11, 1930, p. 64.

${ }^{210}$ Clark S. Beardlee, Hobbies, Vol. 12, 1931, p. 52.

${ }^{211}$ Elon Howard Eton, Memoir I2, N. Y. State Museum, 1910-14.

${ }^{212}$ Lynds Jones, Wilson Bull., Vol. 24, 1912, pp. 171-86. 
${ }^{213}$ M. J. Magee, Wilson Bull., Vol. 34, 1922, pp. 175-6.

${ }^{214} \mathrm{~J}$. Van Tyne, Wilson Bull., Vol. 35, 1923, p. 21.

${ }^{215}$ B. H. Swales and P. A. Taverner, Wilson Bull., Vol. 13, 1906, p. 67.

${ }^{216} \mathrm{Wm}$. L. Kells, $A u k$, Vol. 2, 1885, p. 106.

${ }^{217}$ Herbert Friedmann, $A u k$, Vol. 48, 1931, p. 64.

${ }^{218} \mathrm{G}$. A. MacCallum, Ontario Game and Fish Commission Report, 1892, p. 372.

${ }^{219} \mathrm{Wm}$. H. Smith, Canada: Past, Present and Future, 1851.

${ }^{220}$ Elliott Coues, Misc. Pub. No. 3, U. S. Geol. Surv. of the Territories, 1874, p. 53.

${ }^{221}$ R. D. Ussher, Can. Field-Nat., Vol. 50, 1936, p. 14.

${ }^{222}$ Wm. Perkins Bull, From Humming-bird to Eagle, 1936.

${ }^{223}$ Hoyes Lloyd, Can. Field-Nat., Vol. 50, 1936, p. 144.

${ }^{224}$ Ludlow Griscom, Proc. Bost. Soc. Nat. Hist., Vol. 41, 1937, pp. 126 and 143.

${ }^{225}$ Donald Williams, Bird-Lore, Vol. 28, 1926, p. 202. 



$\mid$

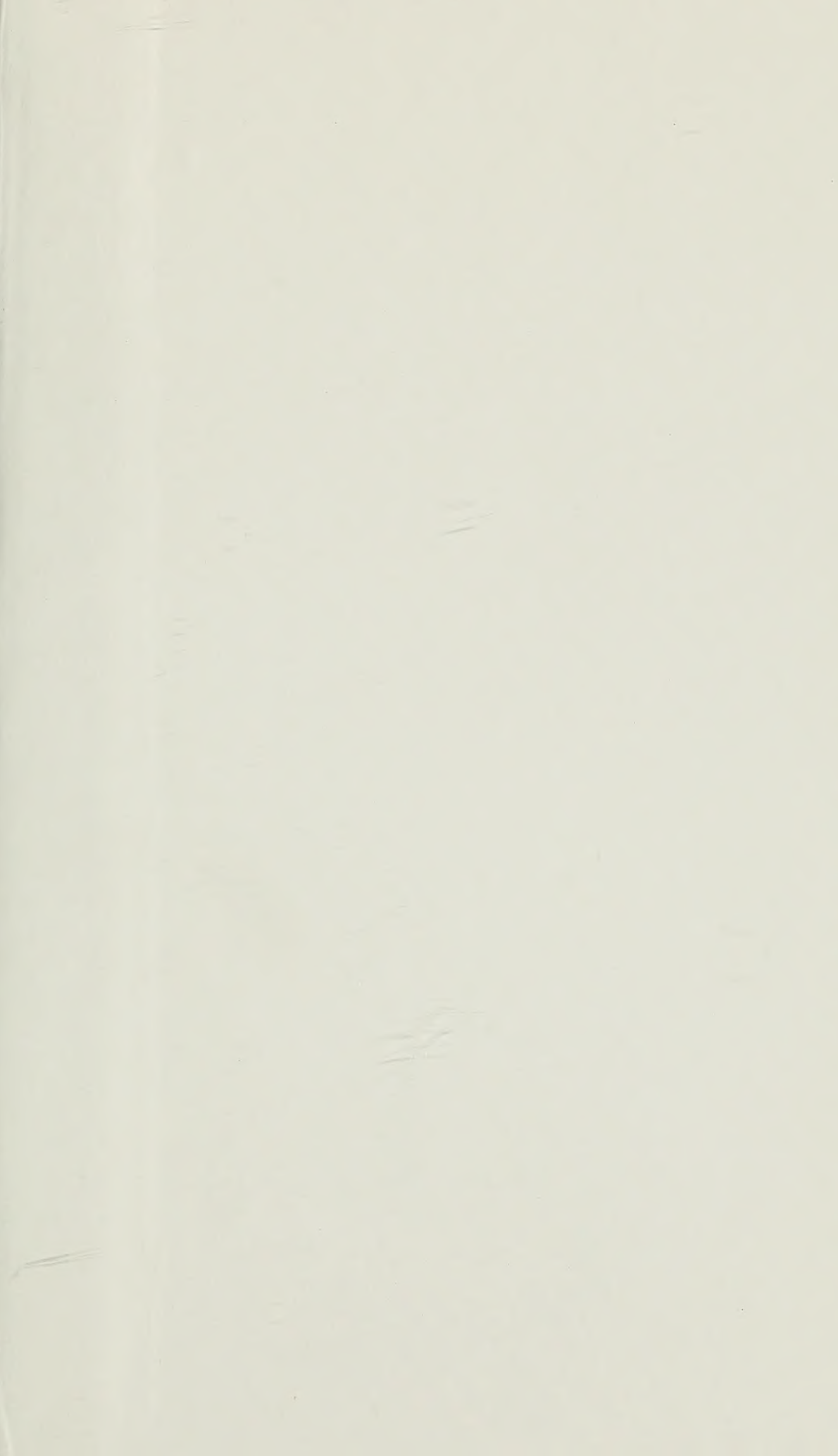


163

W.6.

69.

6.7.

1767)

(7)

yon

3

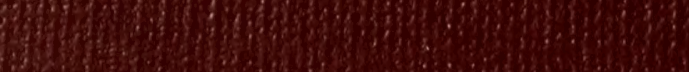

W.

1932 (1) 